Portland State University

PDXScholar

$1-1-2010$

\title{
American Scientists, Americanist Archaeology: The Committee on Radioactive Carbon 14
}

Keith David Baich

Portland State University

Follow this and additional works at: https://pdxscholar.library.pdx.edu/open_access_etds Let us know how access to this document benefits you.

\section{Recommended Citation}

Baich, Keith David, "American Scientists, Americanist Archaeology: The Committee on Radioactive Carbon 14" (2010). Dissertations and Theses. Paper 168.

https://doi.org/10.15760/etd.168

This Thesis is brought to you for free and open access. It has been accepted for inclusion in Dissertations and Theses by an authorized administrator of PDXScholar. Please contact us if we can make this document more accessible: pdxscholar@pdx.edu. 
American Scientists, Americanist Archaeology:

The Committee on Radioactive Carbon 14

\author{
by \\ Keith David Baich
}

A thesis submitted in partial fulfillment of the requirements for the degree of

\author{
Master of Arts \\ in \\ History
}

Thesis Committee:

Richard H. Beyler, Chair

Kenneth M. Ames

Katrine Barber

David A. Johnson

Portland State University

(C)2010 


\begin{abstract}
Willard Libby's development of carbon-14 dating at the University of Chicago immediately following World War II provided an unprecedented opportunity for the collaboration of archaeologists with a physical chemist. Libby's need for archaeological samples to test the dating process (1947-1951) meant that he relied upon the Committee on Radioactive Carbon 14, formed by the American Anthropological Association, for datable materials, as well as for assistance in all other archaeologically related aspects of the testing phase. The committee, under the leadership of archaeologist Frederick Johnson, served the mandated function of providing assistance to Libby, but simultaneously endeavored to utilize the new dating method to promote the development of the authority of anthropological professional organizations and further establish Americanist archaeology in a national and global context. Johnson's and the committee's approach to collaboration was informed by an understanding of opportunities provided by the postwar restructuring of the sciences.

The purpose of the present study is to provide a history of the Committee on Radioactive Carbon 14 (1948-1952) as well as a to provide the context necessary to describe the bureaucratic and scientific goals of the committee. Frederick Johnson's career, and the manner in which it reflected general trends in twentieth century American anthropology, is discussed in detail, and utilized to present an explanation of his actions as committee chair. Willard Libby's development of carbon-14 dating is also discussed in detail, particularly in regard to his request for assistance from the archaeological community and subsequent collaborative work.
\end{abstract}

The undeniable influence of carbon-14 dating on archaeological practice worldwide, 
and Libby's acceptance of the Nobel Prize in Chemistry (1960) for his development of the dating method, has provided reason enough for a plethora of articles and book length studies regarding carbon-14 dating. Yet, little has been written about the Committee on Radioactive Carbon 14 and its place in an analysis of the bureaucratic and collaborative science of the American mid-century. It is for this reason that the present study was undertaken. 


\section{Acknowledgements}

A grant by the PSU Friends of History made possible a research trip to UCLA to access the Frederick Johnson Papers, and therefore was of great assistance. Dr. Richard Beyler's comments and close reading of drafts of the thesis was most helpful. The thesis committee: Dr. Richard Beyler, Dr. Katrine Barber, Dr. David Johnson, and Dr. Kenneth Ames, all provided assistance with their commentary and in numerous ways. I would like to thank Dr. Jessica Wang of the University of British Columbia for a helpful discussion regarding Willard Libby and his relationship (or perhaps lack there of) with the Atomic Scientists movement. I would also like to thank my wife, Maura Brown, for her support and editorial assistance in the final stages of the manuscript. 


\section{Contents}

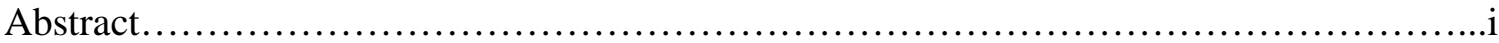

Acknowledgements...........................................................ii

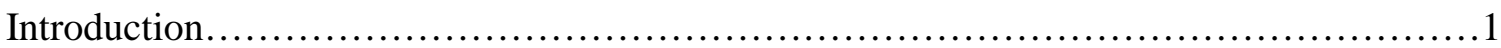

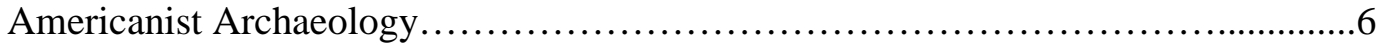

The All Powerful Atom..................................................... 13

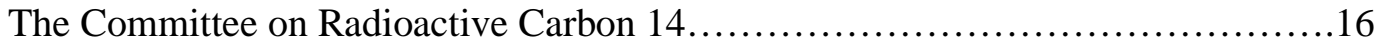

Chapter One: Frederick Johnson and Twentieth Century Americanist Archaeology.............18

"Exhibit Quality" Collections.................................................... 18

The Development of Americanist Archaeology......................................27

Johnson and Archaeology ....................................................... 33

Johnson's Development of the CRAR.......................................42

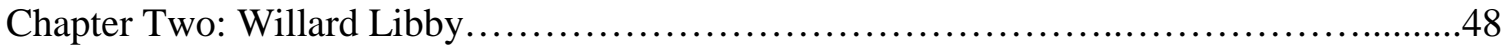

Carbon-14 Dating, Government Research and Basic Science......................51

Libby Attempt at Apolitical Science...........................................56

Development of the Carbon-14 Dating Method...................................59

Libby, Arnold, and the Archaeologists.....................................64

Chapter Three: The New Committee...............................................69

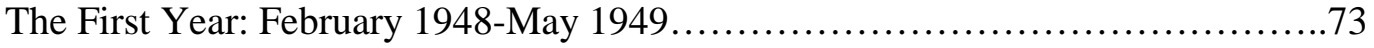

Chapter Four: The Committee Collaborators.........................................89

Other Laboratories...................................................... 100

Release of Dates, Disbanded Committee (January 1950-January 1952).............105

Conclusion..........................................................................

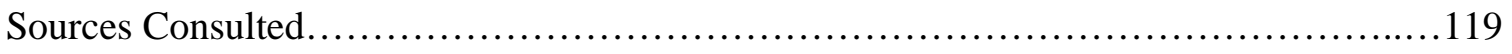

Appendix A: Explanation of Carbon-14 Dating.................................... 127

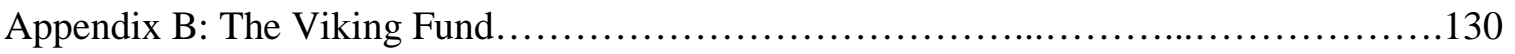

Appendix C: Acronyms and Abbreviations........................................132 


\section{INTRODUCTION}

On July 12, 1948, Willard Libby's research associate James Arnold used the carbon14 dating method in development at the University of Chicago's Institute for Nuclear Studies to date the first archaeological specimen - an acacia wood fragment found inside the step pyramid of Zoser at Sakkara. ${ }^{1}$ The piece had come to the researchers over a year earlier by circuitous route: over Christmas break 1946-1947, Arnold had happened to mention to his father, A.S. Arnold, Libby's idea to ascertain the of the age of objects using a method of counting of radioactive isotope decay. Arnold's father, an amateur archaeologist and Egyptologist, had taken it upon himself to call his friend Ambrose Lansing at the Metropolitan Museum of Art who in turn sent along unsolicited samples to be tested. When Arnold returned to the University of Chicago after the Christmas break in January a package was waiting there for him. To his surprise, it contained eleven samples, all from Egyptian excavations. Arnold showed it to Libby, albeit sheepishly_Libby had only recently announced the project to his closest colleagues (including Arnold) at a December 1946 Christmas party, and had kept his earlier ruminations concerning the dating method to himself. Arnold wondered if he had overstepped his bounds by involving his father and an outside archaeologist; he offered to return the package, but Libby set the samples on a desk

\footnotetext{
${ }^{1}$ James R Arnold, "The Early Years with Libby at Chicago: A Retrospective," in Radiocarbon After Four Decades: An Interdisciplinary Perspective, ed. R.E. Taylor, A. Long, and R. S. Kra (New York: Springer-Verlag, 1992), 6. R.E. Taylor, "The Introduction of Radiocarbon Dating," in It's About Time: A History of Archaeological Dating in North America, ed. Stephen Nash (Salt Lake City: University of Utah Press, 2000), 91.
} 
shelf, silently relating his intentions. ${ }^{2}$

Despite the arrival of the serendipitous package, Libby and team were uncertain as to how to enlist the aid of archaeologists to test the dating process following their initial technical advances of 1946 and early 1947. The difficulty was precipitated by the lack of structured routes of communication between physical scientists and archaeologists within academia. Yet the restructuring of academic departments and other scientific institutions, promoted to produce peacetime applications for new technologies, would become one of the hallmarks of the postwar period, and the application of Libby's research to archaeology should be noted as one of the most successful examples of collaboration between the physical and social sciences in the era.

Prompted to present his research across academic departments by senior faculty, through the end of 1947 Libby introduced his work in a series of lectures and meetings to anthropologists. A number of competing factions of archaeologists positioned themselves to spearhead a collaborative test of the dating method. In short order, the task of integrating the process into archaeology fell under the auspices of the American Anthropological Association (AAA). The professional organization appointed a committee chaired by Frederick Johnson, the Committee on Radioactive Carbon 14 (CRC14), to administer the collaboration of archaeologists, geologists, and physical chemists sought by Libby. The central place of a professional organization and committee, and that committee's actions and decisions, testify to postwar attempts by archaeologists to restructure the bureaucratic organization of Americanist archaeology in the service of professional organizations and not academic departments.

\footnotetext{
2 Arnold, 6. See also Greg Marlow, "Year One: Radiocarbon Dating and American Archaeology," American Antiquity 64 (1999): 12.
} 
Libby's development of the carbon-14 dating process, and its effect on modern archaeological practice have both been stated multiple times, in some detail, by other scholars. ${ }^{3}$ Yet, just as pertinent to historical understanding of carbon-14 dating is the manner in which the method was introduced to archaeologists, tested through collaboration between physical chemistry and stratigraphic archaeology, and integrated into archaeological practice. This thesis will relate the history of the $\mathrm{CRC} 14$, and in doing so relate the multi-disciplinary collaboration to trends present in postwar archaeology and postwar American sciences. Many have pointed to the carbon-14 era as greatly divergent from prior archaeological practice, and this thesis will not deny that the new technology affected methodology, particularly in Americanist archaeology circles. But it will show that the integration of carbon-14 dating by the committee relayed a continuation of developing goals particular to the Americanist discipline. The committee, and Frederick Johnson, utilized the new dating method to promote the further power and professionalization of Americanist archaeology, and to further distinguish and delineate North American archaeology from early twentieth century ethnology and the archaeology of Europe and the Middle East. ${ }^{4}$ The discussion thereby relates the contention of historians of science that the manner in which innovations are integrated into practice is often governed as much by the social and structural tropes

\footnotetext{
${ }^{3}$ Many authors, many of them archaeologists themselves, have noted the affect of radiocarbon dating on archaeological practice. See R.E. Taylor, Radiocarbon Dating: An Archaeological Perspective (New York: Academia Pres Inc., 1987), 143-146, and R.E. Taylor, "The Introduction of Radiocarbon Dating," 100-104. Earlier discussions of the effect of radiocarbon dating on field practices occurred in the works of archaeologists Frederick Johnson, William G. Haag, and many others.

${ }^{4}$ See Colin Renfrew, Before Civilization: The Radiocarbon Revolution (New York, Alfred A. Knopf, 1973) and R.E. Taylor, Radiocarbon Dating: An Archaeological Perspective (New York: Academia Pres Inc., 1987). Frederick Johnson also spoke numerous times about the great impact of radiocarbon dating on practice, perhaps most decisively in "The Impact of Radiocarbon Dating Upon Archaeology," in Proceedings of the Sixth International Conference Radiocarbon and Tritium Dating: Held at Washington State University, Pullman Washington, June 7-11, 1965, ed. Roy M Chatters and Edwin A. Olson (Washington: Division of Industrial Research, 1965), 762.
} 
existent within a discipline as by utility.

Chapter 1 begins the thesis with a discussion of Americanist archaeology and the career of CRC14 chair Frederick Johnson, illustrating the early twentieth-century development of archaeological chronologies apart from ethnological practice, and the context for Johnson's interest in carbon-14 dating. The chapter charts Johnson's transition from field ethnologist to administrative archeologist who emphasized the greater power of professional organizations, and his development into a member of what historian of archaeology Paul Fagette dubs archaeology's "managing paradigm.",

The contention that the twentieth century saw a growth in bureaucratic structures is not limited to discussions of archaeology, or even of the sciences, and can be noted as well in primary sources of the period. ${ }^{6}$ Therefore, Johnson's role as a science administrator, and his promotion of bureaucratic goals had political and ideological ramifications. The timing of the development of carbon-14 dating (in the post-World War II era) coincided with the continued alignment of science resources (organizations, funding, facilities) with large-scale models in the service of national science policy, a policy greatly informed by the war effort. The work of the CRC14 coincided with postwar debate regarding the structuring of science, initiated by Vannevar Bush's report to President Truman, Science, The Endless Frontier, in 1945. ${ }^{7}$ The restructuring of the sciences, which greatly influenced the manner in which the physical sciences would be funded, also suggested the possibility of further funding and

\footnotetext{
${ }^{5}$ Paul Fagette, Digging For Dollars: American Archaeology and the New Deal (Albuquerque: University of New Mexico, 1996), 3.

${ }^{6}$ See, for example, James Burnham, The Managerial Revolution: What is Happening in the World (Bloomington: University of Indiana Press, 1941), discussed in further detail in Chapter 2. See also, Michael Polanyi, The Logic of Liberty: Reflection and Rejoinders (Chicago, University of Chicago Press, 1945), 3-7.

${ }^{7}$ Vannevar Bush, Science, The Endless Frontier (Washington: Office of Scientific Research and Development, 1945).
} 
professionalization for archaeology, and archaeologists like Johnson attempted to foster the bureaucratic powers of professional organizations in the context of this window of opportunity. In the interest of funding, Johnson and colleagues would also relate the stewardship of archaeological sites to the protection of the national interest and national heritage, utilizing the language of national science policy to further archaeology's goals. ${ }^{8}$ The conditions that precipitated these developments, namely the new funding mechanisms and the growing authority of professional anthropological organizations, are related in the chapter to Johnson's career trajectory and his leadership of the CRC14.

Discussion of the archaeological collaboration in service of carbon-14 dating will be aided by an overview of Libby's work with radioactive isotopes in Chapter 2. The surplus of atomic materials created by atomic testing meant that isotope research received funding and promotion after World War II from government agencies and individuals in academia and the private sector, but radioactive isotopes had also been Libby's main interest as a young physical chemist prior to his Manhattan Project commission. His work with radioactive isotopes, culminating in carbon-14 dating, illustrates the difficulty in delineating basic science from applied science, a distinction shaped by the debate of the postwar period.

The effect of isotope research and atomic science on postwar (post-atom bomb) American society was immeasurably large, and can be contrasted with the less recognized

\footnotetext{
${ }^{8}$ Duncan Strong, Frederick Johnson, and William S. Webb, "National Archaeological Resources," Science 102 (1945): 44. See also J.O. Brew, et al. "Symposium on River Valley Archaeology," American Antiquity 12 (1947): 209-225. Johnson was one of the authors of this summary of a symposium regarding salvage archaeology penned by the influential Committee for the Recovery of Archaeological Remains (CRAR) and a few influential members of the SAA. Therein, Johnson's colleague Duncan Strong argues it would be "disastrous" for "present and future citizens of the United States" if archaeologists and the government neglected to salvage archaeological remains prior to destruction by Federal projects. In a statement that speaks to the ideological aspects of the restructuring of the sciences he notes that "most foreign nations" require salvage archaeology and that the Soviet Union characterizes archaeological artifacts as "belonging to the nation," and requires excavation prior to government sponsored development projects (pg. 210-211). Johnson's relationship to the CRAR is discussed in detail in Chapter 1.
} 
changes to American archaeology. Willard Libby's work and the manner in which it was

funded, perceived, and integrated into archaeology also serves to illustrate particular trends in postwar science.

Chapters 3 and 4 provide a history of the operations of the CRC14, highlighting the relationship of Willard Libby and the committee members. The chapters will illustrate the ways in which committee decisions and actions furthered multi-layered bureaucratic and scientific goals - goals related to beliefs about the authority of professional organizations and related to perceived deficiencies within Americanist archaeology. Most notably, Frederick Johnson and his colleagues on the committee paid particular attention to the usefulness of Libby's dating method to further chronologies on the North American continent. This tendency, to frame organizational and experimental science in national (verses regional or international) terms, related to the wartime and postwar organization of American science.

\section{Americanist Archaeology}

As late as the 1920s the archaeology of North America remained a small aspect of ethnological practice, not a separate discipline. Chronological concerns in regard to indigenous Americans were of little interest, far behind a study of present day peoples and the procurement of exhibit quality ethnographic materials for museum display. Americanist anthropology was thereby distinct from the archaeology of Europe and the Middle East, where chronologies were central to practice. The subordinate place of chronologies in American anthropology had roots in challenges that Americanists faced, including the scarcity of pre-Columbian written sources, long held theoretical contentions that American Indians had very recently migrated from Asia, and contentions that Indian culture had 
remained largely static. ${ }^{9}$ Although the rise of Boasian ethnology in the late nineteenth century did work to divorce theories of Native American culture from conceptions of stagnation or degeneration, it did not immediately facilitate an archaeological attempt to establish cultural change in relation to a historical chronology.

In the American academic setting, Americanist anthropology was less venerated than the archaeology of Europe and the Middle East. Whereas the stunning discoveries of ancient treasures and the recovery of Biblical sites in the Middle East from the mid-nineteenth century onward fostered academic and public interest (and funding) for "Old World" archaeology, no events had hoisted the ancient peoples of the Americas onto a similarly high stage. Methodological and theoretical distinctions between "Old World" and "New World" were deeply rooted, and stemmed from the independent development of the disciplines within distinct academic fields. Work in the United States regarding Native Americans had come out of anthropology departments, whereas work done by Americans in Europe and the Middle East was connected to classics departments, and divinity schools, and developed out of a study of ancient texts, the Bible, and languages. ${ }^{10}$ These distinct paths of development yielded distinct theoretical and methodological norms. Archaeology of Europe and the Middle East, with its relations to the classical texts of the Western academic tradition, connected finds to the historical development of "culture" (perceived in the singular, not the

\footnotetext{
${ }^{9}$ Bruce G. Trigger, “Archaeology and the Image of the American Indian," American Antiquity, 45, no. 4 (1980): 662-664.

${ }^{10}$ See Colin Renfrew, "The Great Tradition Verses the Great Divide: Archaeology as Anthropology?" American Journal of Archaeology 84 (1980), 287-298. See also Bruce Kuklick, Puritans in Babylon: The Ancient Near East and American Intellectual Life 1880-1930 (Princeton: Princeton University Press, 1996), 30. Kuklick notes, “'Americanists' were less honored than students of Greece, Egypt, and Mesopotamia and labored under the burden of studying 'savages.",
} 
plural), whereas anthropologists in North America, in the eyes of many, "labored under the burden of studying 'savages.",11

Anthropologists R. Lee Lyman, Michael J. O’Brien, and Robert C. Dunnell argue that recognizable aspects of modern American archaeological practice-particularly those regarding migrations, cultural change, and cultural diffusion-were not in favor until after the acceptance of the "culture history" movement of the second decade of the twentieth century. ${ }^{12}$ The culture history phase of Americanist practice developed based upon relative chronologies using southwestern pottery shards, dendrochronology, and components of cultural diffusion developed through ethnological studies. Growing emphasis on chronologies and continental migration fueled a greater methodological divide between ethnological and archaeological practice, and Americanist archaeologists soon developed a professional organization to administer an independent discipline, the Society for American Archaeology (SAA), formed in 1935. The flagship journal of that organization was (and remains) American Antiquity. The development of this organization marked the growth of Americanist archaeology apart from anthropology and ethnology, both better promoted by the long-standing and prestigious AAA. The SAA also served to distinguish Americanist endeavors from the archaeology done by Americans in the Middle East and Europe, better served by the older American archaeological organization, the American Institute for Archaeology (AIA). ${ }^{13}$

${ }^{11}$ Kuklick, Puritans in Babylon, 30.

${ }^{12}$ R. Lee Lyman and Michael J. O'Brien, The Rise and Fall of Culture History (New York: Plenum Press, 1997), 1. The authors go so far as to describe culture history as the "first formal paradigm of Americanist archaeology," self consciously evoking Kuhn's terminology in a number of places: v, 1, and 13.

${ }^{13}$ Both the AAA and the AIA do not officially exclude American archaeology under the umbrella of interests and support, though it is clear in each case that other interests have long dominated the 
The development of Americanist archaeology coincided with the large-scale professionalization of many scientific disciplines in America. Early to mid twentieth century changes to academia, industry, and the funding of the sciences by government and private interests, precipitated the development of authoritative and administrative structures in the sciences, sometimes in the form of professional organizations. From within archaeology, individuals like Johnson promoted the authority of professional organizations above that of academic departments or regional archaeology. Johnson's work towards a centralized authority in Americanist archaeology (verses regional authority administered by universities) was facilitated by the emergence of New Deal sponsored archaeology and therefore the emergence of funding avenues for large-scale archaeological projects. ${ }^{14}$ The opportunities provided during the transitionary 1930s has led anthropologist George Quimby to point to it as "the Golden Age of [Americanist] Archaeology.","15

Many have utilized Alvin M. Weinberg's term "big science," to characterize the development of large-scale science in the twentieth century. ${ }^{16}$ Such science is understood as involving the collaboration of a number of scientists and supported by a well-funded administrative structure designed to manage these resources. Yet, also related to the rise of big science is the waning of a nineteenth century model for academic science. Wolfgang $\mathrm{K}$.

associations. For a discussion of the divide between the AIA and Americanist archaeology see Colin Renfrew, "The Great Tradition." In an edition of the journal meant to commemorate the $100^{\text {th }}$ anniversary of the AIA, Renfrew notes the tendency of the AIA to ignore work done in the Americas and to dismiss the theoretical contentions of Americanist archaeologists. He outlines the historical aspects of this "great divide" and argues for greater cooperation in the future.

${ }^{14}$ Faggette, chapters 2,3, and 4. See also, Edwin A. Lyon, A New Deal for Southeastern Archaeology (Tuscaloosa, The University of Alabama Press, 1996).

${ }^{15}$ Faggette, 19.

${ }^{16}$ Alvin M. Weinberg, "Impact of Large Scale Science on the United States," Science 134 (1961), 161-164. See also Derek J. De Solla Price, Little Science, Big Science (New York: Columbia University, 1963). 
H Panofsky in "Big Science and Graduate Education," distinguishes between "big science" and "little science" in relation to academic research, arguing that "little science" is "research carried out in the traditional academic pattern; that is, research supervised by a professor, assisted by graduate students... and supported by some central shop facilities." This definition well describes the fieldwork of Johnson's early career through the 1920s, overseen by mentor and educator Frank Speck, connected to the University of Pennsylvania, and conducted in the service of museum collections. The definition, similarly, well describes the majority of the archaeological work of Johnson's contemporaries in the period before the salvage archaeology of the 1930s. In contrast, Panofsky defines "big science" as "research where investigators generally operate in a group and where, in effect, some segment of industry is mobilized to support the work."17 Johnson's interdisciplinary work on the Boston Fishweir projects of the late 1930s, and his work for the CRC14 serve as solid examples of this definition. Indeed, the fact that Libby's request for archaeologist assistance eventually fell under the auspices of a professional organization committee and not the nearby University of Chicago anthropology department (or the related University of Chicago Oriental Institute) is further illustration of the greater trend-towards greater oversight of large scale projects by professional organizations.

Harold Orlans discussion of the effect of government funding on higher education corroborates Panofky's findings. American archaeology, echoing the structure of projects in the physical sciences, came to be funded in a model that Orlans dubs "the project system," in which both government and philanthropic organizations shifted away from the funding of university departments and instead funded digs, experiments, and other projects marked by

\footnotetext{
${ }^{17}$ Wolfgang K. H Panofsky in "Big Science and Graduate Education," in Science Policy and the University, ed. Hans Orlans (Washington D. C.: The Brookings Institution, 1968), 189.
} 
specific timelines and quantifiable goals. Grants like those given by the National Science Foundation and National Institutes of Health were often examples of such funding, as were the New Deal sponsored archaeology projects. Orlans states that the consequence of this evolution was a "shift of power from individual faculty to...' faculty as a whole' and to more readily identifiable administrators." 18 In some cases, administrators like Johnson were more closely aligned to professional organizations than to academic departments, in accord with the emerging funding model. Consequently, archaeological digs funded through New Deal legislation in the 1930s, and directed by the Federal Emergency Relief Administration (FERA), the Conservation Corp (CCC) and The Works Project Administration (WPA) precipitated in the development of archaeologists as administrators of large-scale, multiorganizational projects.

Project oriented funding and the development of scientific administrators grew hand and hand through the New Deal, and greatly increased in certain fields during the war (often in relation to strategically applicable technologies). Yet, despite the wartime emphasis on physical sciences, the need for administrators like Johnson (who served in the Navy during the hostilities) continued to develop and characterized the administration of the social sciences in the post-war decades.

Chapter 1 will illustrate that the evolution of Johnson's duties reflected changes to the science model that had affected both the physical and the social sciences. It is also to note that as the new model arose, Johnson and some like-minded colleagues promoted the compliance and adaptation of archaeological practice to the new funding apparatus and growing bureaucracy. Historian Marilyn Norcini describes Johnson's administrative

\footnotetext{
${ }^{18}$ Hans Orlans, The Effect of Federal Programs on Higher Education: a Study of 36 Universities and Colleges (Washington D.C.: The Brookings Institute, 1962), 3-10.
} 
leanings, explaining that he was "a man who had the vision and social networks to design and manage innovative projects that broadened the influence and authority of anthropology as a science, regionally, nationally and globally."19 Yet Johnson was not simply a man with unique talents, but a member of an emerging class of administrative social scientists.

Historians of the social sciences Jonathan Cole and Stephen Cole relate the twentieth century emergence of the institutionalized scientific community to the central role of "scientist administrators" whose actions greatly effect the direction of scientific inquiry. ${ }^{20}$ The authors describe the role of these practitioners in modern scientific practice, explaining that they reach "the highest strata of the institution of science through their organizational skills," "get large scale projects off the ground and see them through to completion," and often "serve as 'gatekeepers' to many of the government-controlled resources." For Johnson, gatekeeper status related to his control over the resources of professional organizations, namely the SAA and AAA, and his relationship with individuals who managed philanthropic funds earmarked for anthropology projects. Niche roles, like that of Johnson's, grew in social acceptability and prestige through the mid-twentieth century; Cole and Cole note that accolades and prestige go to those that make up a group of elite administrators nearly as often as to those who shape their field with experimental advances. ${ }^{21}$ It is for this reason that Johnson's obscurity today is particularly enigmatic.

\footnotetext{
${ }^{19}$ Marilyn Norcini, "Frederick Johnson's Canadian Ethnology in the Americanist Tradition," Histories of Anthropology Annual no.4 (2008), 107.

${ }^{20}$ See for example Robert K. Merton and Harriet Zuckerman, "Institutionalized Patterns of Evaluation in Science," in The Sociology of Science: Theoretical and Empirical Investigations (Chicago: University of Chicago Press, 1979), 460-497, and Jonathan R. Cole and Stephen Cole, Social Stratification in Science (Chicago, University of Chicago Press, 1973), among many others.

${ }^{21}$ Jonathan R. Cole and Stephen Cole, 41.
} 


\section{The All Powerful Atom}

When a colleague questioned Frederick Johnson as to his ability to acquire funding for a committee venture involving Libby's unproven dating method, Johnson quipped that he "had no qualms about financing such a thing because these days people are standing on street corners throwing dollar bills at anyone who can say "radioactivity.",22 The collaborative effort with Libby provided Johnson and the AAA a further opportunity: to align the archaeological organization with greatly lauded developments in the burgeoning fields of radioactive isotope and atomic research. The possibility of greater exposure for archaeology in postwar public and bureaucratic perception was not lost on Johnson or many of his colleagues.

Libby's application of isotopes for a carbon-14 dating coincided with a post-war interest in promoting the benefits of isotope and atomic technologies for peacetime uses. Though Eisenhower's “Atom's for Peace” initiative would not begin until late 1953 (tellingly, Libby would be appointed to head that initiative) the AEC began promoting isotopes for postwar use immediately after the war when it became clear that testing and weapons manufacture would provide surplus materials. AEC road shows and exhibitions like "Main Street Meets the Atom," and "The Atom, Servant of Man," promoted utopian uses of the new technology. ${ }^{23}$ Visions of travel in atomically fueled cars, planes and trains, as well as plans to control climate, grow food and cure disease, were legion in the late 1940s, all

\footnotetext{
${ }^{22}$ Johnson to Wedel, July 21, 1947 as quoted by Marlowe, "Year One,” 17.

${ }^{23}$ Ellen Leopold, Under the Radar: Cancer and the Cold War (New Brunswick, Rutgers University Press, 2009), 32.
} 
fostered by idealized conceptions of the uses for atomic energy. ${ }^{24}$

So ubiquitous was discussion of the effect of atomic science on modern life that the AAA passed a resolution at the 1945 annual meeting that pointed out "the responsibility of anthropologists to study the effects of the discovery of the use of atomic energy," and also to "guard against the danger, and utilize the promise, inherent in atomic use." 25 The resolution reflected a growing opinion, as historian Paul Boyer has noted, that social scientists would need to be mobilized to stave off atomic destruction in the wake of the Hiroshima and Nagasaki bombs. ${ }^{26}$ Equally, the inclusion of the phrase "utilize the promise" in the AAA resolution, pointedly included American archaeologists into the emerging group of social scientists who were actively looking for applications of atomic technology within the scope of their professional and academic pursuits. The resolution thereby facilitated the atmosphere necessary for the creation of a committee to work with Libby.

The conception of carbon-14 dating as intimately tied to atomic science-a relationship fostered by Johnson and a few other archaeologist commentators-was part reality and part conflation. Libby had been a Manhattan Project scientist and his work with nuclear reactors and uranium isotope separation had furthered aspects of his postwar work development of carbon-14 dating (discussed in Chapter 2). Yet carbon-14 dating utilized a naturally occurring, not reactor made isotope, and was therefore not a part of the growing government surplus of reactor produced radioactive isotopes. ${ }^{27}$ But Libby's postwar position

\footnotetext{
${ }^{24}$ Paul S Boyer, By the Bomb's Early Light: American Thought and Culture at the Dawn of the Atomic Age (New York: Pantheon Books 1985), 109-115.

${ }^{25}$ M. F. Ashley Montagu, "the Atomic Bomb and the Anthropologists," Science 103, no. 2679 (1946): 570.

${ }^{26}$ Boyer, 168-169.
} 
at the University of Chicago was related to the promotion of practical applications of isotopes to civilian life. Robert Hutchins, chancellor of the University of Chicago, was an early believer in the power of atomic energy to shape everyday life. He endeavored to bring Manhattan Project scientists Libby and Harold Urey, to the University of Chicago immediately after the war to keep the university at the forefront of atomic science. ${ }^{28}$ The complex relationship of Libby's carbon-14 dating process to contemporary concepts of applied and basic science is discussed in Chapter 2.

Of further interest was Libby's attempt at an apolitical presentation of carbon-14 dating despite its revolutionary effect on chronologies and archaeological practice. Boyer notes that the atomic scientists at the University of Chicago post-World War II were especially politically vocal and active. Numerous scientists who had worked on the Manhattan Project in the University of Chicago's Metallurgical Laboratory, including James Franck, Leo Szilard, Eugene Rabinowitch, and Glenn T. Seaborg, signed the 1945 Franck report. Similarly, Rabinowitch, Szilard, and Urey joined Einstein in calling for international control over atomic energy in the years directly after the war. ${ }^{29}$ Many of Libby's colleagues would become active in different aspects of the "atomic scientist's movement." 30 Though the group included Libby's colleague and mentor Harold Urey, Libby was not counted among those who engaged in the movement. Libby instead was content to continue education and

\footnotetext{
${ }^{27}$ See Ellen Leopold, Under the Radar. Also N. H. Creager, "Nuclear Energy in the Service of Biomedicine: The U.S. Atomic energy Commission's Radioisotope Program, 1946-1950," Journal of History of Biology 39 (2006), 649-684.

${ }^{28}$ Paul Boyer relates that Hutchins's call for international peacetime use of atomic power was pointed to by contemporary observers as motivated by “his desire to replace Chicago's 'bomb factory' image with a more positive one." Boyer, 39.

${ }^{29}$ Boyer, 35-36.

${ }^{30}$ Jessica Wang, American Science in an Age of Anxiety (Chapel Hill, University of North Carolina Press, 1999), 12. Boyer, throughout.
} 
research goals, which in turn yielded one of the most successful (if not the most successful) applications of isotope technology to private sector use in the form of carbon-14 dating. Though Libby's reticence to voice decisive political opinions at this time did not shelter him from ideological and political complications related to Cold War era discussions of the manner in which science was to be structured to serve the national interest. Yet, his silence in regard to the scientist's movement may indeed provide a clue to his high-profile government appointments in the late 1950 s and early 1960 s. $^{31}$

\section{The Committee on Radioactive Carbon-14}

The CRC14, formed by the AAA to assist Libby in the development of the carbon-14 dating system, worked from February 1948 until January of 1952, a little less than four years. In that time the committee provided archeological and geological samples for testing and facilitated the release of testing assay dates. Beyond the mandated scope of the committee's duties, Frederick Johnson and the other committee members were aware that the development of carbon-14 dating would provide numerous advancements for archaeology in general and Americanist archaeology in particular. The dating method presented Americanist archaeology with a potential antidote to the longstanding difficulties with chronology in North American sites. It also provided the impetus for a series of field techniques that would further demarcate the work of professional archaeologists from amateurs. Johnson in particular was aware that the development of the method would provide a catalyst for the

\footnotetext{
31 “Science: The Philosopher's Stone.” Time, August 15, 1955, http://www.time.com/time/ magazine/article/0,9171,807508,00.html, accessed June 4, 2010. Also Nobleprize.org, biography of Willard Libby http://nobelprize.org/nobel_prizes/chemistry /laureates/1960/libby-bio.html, accessed June 4, 2010. Accessed June 10, 2010.
} 
development of uniform field practices and further align American archaeology with atomic science and the far greater funding potential realized by the physical sciences. Johnson endeavored to extend the authority of the AAA and other American professional organizations through the successful integration of carbon-14 dating into archaeological practice, by using those organizations' publications as a clearinghouse for dates, by publishing the preliminary reports on carbon-14 dating through those organizations, and by attempting to set up a dating facility run by a professional organization.

Once the collaborator phase began (Chapter 4) the committee's work was complicated by the growing number of individuals—archaeologists, geologists, and physical scientists-who had access to the test data and a sense of the project's parameters. In this phase the committee struggled to control the release of dates produced through testing which had not yet approved for use by Libby and his team. The committee's relationship to this data shifted greatly within this period, revealing discrepancies between the committee's and Libby's understanding of the testing phase.

This thesis will discuss the history of the committee in detail, relating the committee to Johnson's career and general trends in American archaeology and to trends in twentieth century science. The discussion utilizes the records of the CRC14, which make up a large portion of the Frederick Johnson collections 1948-1968, housed in the Charles E. Young Research Library at UCLA. ${ }^{32}$ Johnson's administrative work culminated in his work with the CRC14, and therefore it is through a close reading of the primary sources related to the committee that a majority of the analysis briefly outlined will unfold.

\footnotetext{
${ }^{32}$ See "Finding Aid for the Frederick Johnson Papers, 1948-1968," Online Archives of California, http://www.oac.cdlib.org/findaid/ark:/13030/kt296nc30m. Collection number 1295: 9 boxes of correspondence, meeting minutes, etc. From here on the collection will be referred to as FJP.
} 


\section{CHAPTER 1: FREDERICK JOHNSON AND TWENTIETH CENTURY AMERICANIST ARCHAEOLOGY}

\section{"Exhibit Quality" Collections: Frederick Johnson and Ethnology}

Frederick Johnson's life spanned the twentieth century (1904-1994), and his evolving interests reflected the tidal shifts within archaeological practice that occurred throughout the century. This chapter will provide context for Frederick Johnson's work on the Committee on Radioactive Carbon-14 by providing the details both of Johnson's early career and by expressing the general trends in early twentieth century archaeology.

Johnson's introduction to the anthropological sciences occurred when he was a young man of thirteen in 1917-it was then when family friend and University of Pennsylvania anthropologist Frank G. Speck took him on the first of what would become a series of "ethnological field trips to the wilds of Northern Quebec."33 It was Johnson's youthful interest in snakes that prompted the adventures, though there was also much time spent among the Montagnais-Napaski Indians. Johnson and his family's connection with the wellknown and respected ethnologist had been provided a few years prior; they had met Speck on a family vacation in Gloucester, Massachusetts, where Speck owned a cabin (Johnson and family were from Everett, Massachusetts, just north of Boston). Perhaps revealing something of a class discrepancy between the Johnson family and Speck, their introduction was in part facilitated when Johnson's father (a general contractor) was hired to add an addition on to Speck's cabin. This allowed young Frederick time to help Speck work on his canoe paddling technique on the inlets and bays of the region, and the young man's resourceful naturalism no

\footnotetext{
${ }^{33}$ Richard S. MacNeish, “Obituary: Frederick Johnson,” 269.
} 
doubt impressed the ethnologist. ${ }^{34}$

A master-apprentice relationship began that continued to facilitate Johnson's professional growth through his undergraduate studies at the University of Pennsylvania and through his early fieldwork. It was a relationship invested in a tradition of anthropological education that stretched back into the nineteenth century, one in which individual practitioners and academics, like Speck, trained a small group of often hand picked students who, in turn, largely espoused their mentor's methodology. As late as 1935 there were only seven Ph.D. programs in anthropology in the United States, based in four first-generation American universities (Harvard, Pennsylvania, Columbia, Yale) and three well-funded younger institutions (California, Chicago, and Michigan). ${ }^{35}$ Archaeology of the Americas, apart from anthropology, had fewer still dedicated facilities and practitioners. The total number of doctorates received in archaeology between 1895 and 1950 were 476, and 75\% percent of those came from only six American universities. A significant portion of those doctorates would study sites abroad, particularly in Europe and the Middle East. Therefore, the pool of vested professionals who studied the archaeology of American sites was small, and centered around a few academic programs and related museum collections (the Peabody Museum at Harvard, Columbia University and the American Museum of Natural History) or government agencies (the Bureau of Ethnology) and government financed collections (the

\footnotetext{
${ }^{34}$ Marilyn Norcini, “Frederick Johnson's 'River Desert Algonquin' Materials at the University of Pennsylvania Museum: A Collection History,' Journal of the Council for Museum Anthropology 31, no. 2 (2008): 123 .

${ }^{35}$ James B. Griffin, "Society for American Archaeology," American Antiquity 50, no. 2 (1985): 265. Michigan was established in 1817. California was established with the post civil war Merrill land grant. The University of Chicago was established in 1890 by John D Rockefeller, and quickly became a leader in Middle Eastern archaeology. Even when this study turns to carbon-14 and the work of archaeologists in the late forties and early 1950s, most of the principal archaeologists involved were professionally connected to these seven principle universities. Speck had been a student of Franz Boas at Columbia.
} 
Smithsonian). Furthermore, a large number of those archaeologists focused their practice on the archeology of foreign lands, and not the peoples of North America. Consequently in the United States, The glut of amateurs and regional enthusiasts (in comparison to professionals affiliated with institutions) meant that professionals often accepted an advisory role, acting as a consultant for amateurs who would bring finds and questions to institutional archaeologists and ethnologists. ${ }^{36}$ This fostered a dynamic of a two-tiered science, one in which amateurs continued to make up a large percentage of field practice and professionals came together to discuss the way in which fieldwork and methodology should be directed.

Speck in fact had been one of Franz Boas's first graduate students and his interest in living peoples reflected the strong influence of Boasian ethnology. ${ }^{37}$ Therefore, Johnson's introduction to anthropology fell under the auspices of Boas's ethnographic contentions: that the most pressing need in Americanist anthropology was the need to preserve details of culture related to native peoples whose way of life was perceived to be in irreversible decline. The contention that native culture was irreversibly diminishing informed multiple aspects of the period's ethnology and had roots in nineteenth century racialist ideology and federal policy. These theories postulated the decline of native populations precipitated by a hierarchical relationship amongst the "races" and the immutability of racial traits, resulting in the demise of peoples deemed inferior. ${ }^{38}$ Boasian ethnology functioned as a critique of

${ }^{36}$ Fagette, XIV.

${ }^{37}$ J.J. Ahern, "A Guide to the Frank Gouldsmith Speck, 1881-1950, Papers, 1925 -1937," University of Pennsylvania Archives, http://www.archives.upenn.edu/faids /upt/upt50/speck_fg_guide.pdf, 2.

${ }^{38}$ Multitude of sources on this point. See T. J. Ferguson, "Native Americans and the Practice of Archaeology," Annual Review of Anthropology 25 (1996): 64-65, and Trigger, "American Indian," 662676. The prominence of ideas of polygenesis in nineteenth century America, led by Harvard's Louis Agassiz, is but one factor in the racialist understanding of native peoples. See much of the work of George 
racialist conceptualizations, though Boas and his first generation of students (Speck included) only shifted the focus of demise from that of race to that of culture. ${ }^{39}$ By the late nineteenth century, while the biologic demise of Indian peoples seemed less certain the cultural demise became "fact," assured by the close of the American frontier and the march of technological development across the continent. Ethnologists like Speck and Johnson sought to document what was believed to be the fading vestiges of pre-Columbian culture and therefore chose the most remote sites for ethnological work; for Johnson and Speck this meant the Yukon and areas of Quebec. The belief that tribal life was not only diminishing, but in most cases faced a total demise within a generation or two, justified a hurried and sometimes haphazard collecting of tribal ephemera that was, in itself, not above destructive practices. ${ }^{40}$

The continued existence of indigenous peoples in the Americas who could be denoted as separate from or "outside" of the Euro-American experience explains in part the focus on contemporary peoples. Equally, theoretical contentions downplayed differences in present day American Indians and their ancestors and promoted the study of present day cultures as representative of ancestral peoples. A belief in a lack of material cultural change in native cultures was founded upon notions of cultural progress as expressed through stages of development, related to Christian Jurgensen Thomsen's nineteenth century “Three Age

Stocking Jr., including “The Persistence of Polygenist Thought in Post-Darwinian Anthropology," in Race, Culture, and Evolution: Essays in the History of Anthropology (New York: Free Press, 1968), 42-68

${ }^{39}$ The transition had been necessitated by clearly observable data; by the early twentieth century native populations were again on the rise, the "low water mark" having been around 1890 . Therefore the belief in the diminishment of native peoples moved from a focus on population to a belief in the postColumbian continuous erosion of Indian "culture" from a once pristine and largely static form. See David Rich Lewis, "Still Native: The Significance of Native Americans in the History of the Twentieth-Century American West," The Western History Quarterly 24, no. 2 (1993): 203.

${ }^{40}$ Thomas C. Patterson, "The Last Sixty Years: Toward a Social History of Americanist Archaeology in the United States," American Anthropologist 88 (1986): 11. His interest is particularly, archaeologists in the transitional 1920s. He states, "U.S. archaeologists accepted the view that American Indians societies were effectively destroyed or so dramatically transformed by European contact that their arts and crafts were fundamentally different from those recorded by early travelers or ethnographers." 
System" (Stone, Bronze, and Iron Ages). By this conceptualization, American cultures remained technologically and culturally in the Stone Age. ${ }^{41}$ Boas-whose detailed analysis of cultures fostered an understanding of cultural distinction that helped break down the universalist mentality_espoused a belief in the myth of ahistorical primitive cultures. In 1902 he explained, "It seems probable that the remains found in most archaeological sites of America were left by people similar in culture to the present Indians."42 Relying on ethnological concepts of Indian cultural diminution and stagnation, those interested in American archaeology presumed that Native American technological cultural had remained uniquely "unprogressive." This belief, when paired with the contention that human populations had migrated to the Western hemisphere in a late period, seemed to make detailed chronological work superfluous. ${ }^{43}$

Consequently, archaeological work in North America remained one of the lesser tools within the "four-field approach." The approach included "ethnological, linguistic, and folkloristic, and secondarily biological or archaeological" field-methods, espoused in that order. ${ }^{44}$ Practitioners like Johnson were sometimes trained in archaeological practice, though archaeological data was largely eschewed in favor of ethnological data until well into the 1920s. Archaeologically retrieved artifacts were perceived as no more indicative of long held cultural norms than pieces crafted in the last generation before colonial contact. Generally, contemporary and older objects were-for the purposes of ethnological data-largely interchangeable. Objects crafted by a tribal member in relative isolation were assumed more

\footnotetext{
41 Trigger, “American Indian,” 664.

${ }^{42}$ R. Lee Lyman, Michael J. O’Brien, and Robert C. Dunnell, Culture History, 23.

43 Trigger, “American Indian,” 666.

${ }^{44}$ Norcini, “Canadian Ethnology,” 113.
} 
instructive (in regard to cultural analysis) than exhumed finds, particularly when technique (in creation) and functionality (in contemporary use) could be observed first hand by the ethnologist.

Historian and archaeologist Bruce Trigger argues that the conceptualization of the American Indian as "unprogressive" was the basis for the differences of American archaeology from that of Europe and the Middle East. ${ }^{45}$ The conceptualization allowed for a reliance on data culled from modern peoples in the Americas whereas in Europe and the Middle East no such clearly identifiable descendants of ancient cultures remained. Therefore, the archaeology of the Middle East and Europe focused little on the physical living conditions of ancient peoples, and far more on chronologies. Prehistory — the time before written records - was of far less consequence to scholars of Europe and the Middle East in light of the presumed continuity of written sources from present times back to the era described in the Old Testament, a text that was most often treated as a historical document of undoubted verity. The inclusion in its pages of the presumed beginnings of humankind (in Genesis) and a list of Biblical patriarchs in close association with societies of known literacy (Babylon, Egypt) made for a belief in a continuous timeline and a short prehistory. Nineteenth century excavations of Egyptian and Babylonian cities, some of which were accomplished by American universities, had seemed to verify these chronologies by unearthing written records, many of which were then translated and were perceived to corroborate the Biblical narrative. ${ }^{46}$ The decisive goal of the archaeology of the Middle East and Europe-to establish the genealogical relationship of present day European culture backwards, through Rome and Greece to the Biblical patriarchs—-wore the mantle of a noble

\footnotetext{
45 Trigger, “American Indian,” 662.

${ }^{46}$ Kuklick, Puritans.
} 
endeavor distinct from work done in the Americas. ${ }^{47}$ In North America, archaeological work could only hope to solve the mystery of Native American's contested origins; even this problem seemed to some better addressed through a study of culture and linguistics than by excavations of ancient sites unaided by written sources. ${ }^{48}$

Johnson started undergraduate work in 1923 at Tufts, but transferred to the University of Pennsylvania to work under Speck in 1924. Johnson's studies under Speck in the ensuing three years included classes in "primitive religions, anthropology of the Negro, and American archaeology and ethnology." He was to "become a trained ethnologist." began with Speck in 1925 with the Naskapi tribe in a remote area of Quebec. Johnson's work focused not upon digs but upon modern peoples, utilizing "participant-observation fieldwork and collection of linguistic and ethnographic texts." ${ }^{50}$ In the ensuing years he conducted ethnological fieldwork among the Montaagnais (1926), Algonquin (1927-1928, 1928-1929), Ojiba and Potawatomi (1928-1929), River Desert Band (1928-1929), and Montagnais and Mistassini (1930), often in the summer when classes were not in session, and when finer weather allowed professionals, students, and amateurs alike to engage in fieldwork. ${ }^{51}$ His ethnographic output reflected the field techniques of the day: he produced

${ }^{47}$ Clearly there had been a period of prehistory, testified to by the discovery of Paleolithic sites. Yet, the ability of anthropologists in these regions to place categorical distinctions between classical societies (Rome, Greece, and Egypt) and the societies of Paleolithic peoples also facilitated the creation of distinctive fields of Paleolithic anthropology, ethnology, and archaeology. Of course, as Jaroslov Malina et al. note, the Eastern hemisphere's "archaeological and ethnographic division was subjected to mutual influences, and, in some cases, integration." See, Jaroslav Malina, Zdenek Vasicek, and Marek Zvelebil, Archaeology Yesterday and Today: The Development of Archaeology in Sciences and Humanities (Cambridge: Cambridge University Press, 1990), 52.

${ }^{48}$ Nor was it the prime interest of Boasian ethnologists, perhaps to their credit.

${ }^{49}$ Norcini, "River Desert Algonquin," 123.

${ }^{50}$ Regna Darnell, Invisible Genealogies: A History of Americanist Anthropology (Nebraska: University of Nebraska Press, 2001), xviii. 
hundreds of photographic images of native peoples and collected items of technology and culture, presumably through barter with tribal members. ${ }^{52}$

The relationship of Johnson and other ethnographers to the objects collected from tribal peoples tellingly illustrates a number of principles about early twentieth century fieldwork; Johnson's collections were by all rights his own, and he was able to sell the objects he collected to museums to subsidize the cost of fieldwork. For example, his collection of 90 objects acquired during fieldwork with the River Desert Band (the 1928 and 1929 seasons), were sold to the University of Pennsylvania’s museum in 1929 for $\$ 260 .^{53}$ Other pieces recovered in the period found there way to the Museum of the American Indian, New York, at that time a privately funded institution, run by philanthropist George Gustav Heye. $^{54}$

The reliance on funds from museums continued to inform field collection methods, as it had throughout the nineteenth century, sometimes working counter to ethnologists' attempts to relate objects not simply to one another (taxonomic organization) but to specific cultural tropes. Reflecting the methodological dialectic, the collections Johnson sold were accompanied by field notes, captions, and other attempts to contextualize the objects. Yet, despite the development of an ethnological in culture, museums were still interested largely

${ }^{51}$ Norcini, “River Desert Algonquin,” 128.

52 Johnson's photograph negatives are collected in a number of places. The Smithsonian Institution contains 477 negatives. See "Frederick Johnson Photograph Collection, 1915-1931 (bulk 1925-1931)" Archives, Manuscripts, Photographs Catalog: Smithsonian Institution Research Information System, http://siris-archives.si.edu/ipac20/ipac.jsp?uri=full=3100001 !283411!0. Accessed April 2010.

${ }^{53}$ Norcini, “River Desert Algonquin,” 129.

${ }^{54}$ Johnson contributed ethnologic material to the Museum of the American Indian, which he collected during studies of Algonquin, Ojibwa, Potawatomi, and Mi'maq peoples. Johnson's ephemeral collections remain to this day at the University of Pennsylvania and the National Museum of the American Indian (now incorporated into the Smithsonian). See Norcini, "River Desert Algonquin," 127, and Marilyn Norcini, "Canadian Ethnography." 
in "exhibit quality" pieces, which Johnson and other fieldworkers, in need of funding, were compelled to provide. The search for pieces that fit the criterion of "exhibit quality" was often at odds with ethnographers' cultural-scientific interests. ${ }^{55}$ Furthermore, the criterion meant that ethnologists favored pieces of relatively recent manufacture to those less handsome pieces recovered from archaeological sites.

Motivated by two years of subpar grades, Johnson left the University of Pennsylvania and returned to Tufts to finish a degree in sociology in $1929 .{ }^{56}$ Though Johnson had not excelled academically, his fieldwork had fostered a number of connections with organizations and individuals, notably George Heye at the Museum of the American Indian, A. I. Hallowell at the University of Pennsylvania, and a continued relationship with Speck and many of Speck's students. His poor grades are, at first glance, puzzling, and certainly do not reflect a lack of fieldwork, lack of knowledge of tribal languages, or lack of collected materials. By all outside signs, with the exception of his minimal published materials, Johnson was functioning as an ethnologist, even before beginning graduate work. After receiving his undergraduate degree his fieldwork continued, "under the auspices of The Museum of the American Indian," which meant most likely that Johnson supplied the museum with photographs and "exhibit quality" artifacts in return for funding. It is in reference to this work that Johnson's long-time friend and colleague notes, "It was then that the anthropological ethic took hold: when you do fieldwork you publish the results or you do no more fieldwork."

${ }^{55}$ Norcini, "River Desert Algonquin,” 134.

${ }^{56}$ Richard S. MacNeish, "Obituary: Frederick Johnson,” 269. Also Norcini, "River Desert Algonquin, 128, and Norcini, "Canadian Ethnology," 108-109. The question of why Johnson finished with a sociology degree and not a degree in anthropology remains. Perhaps sociology degrees, being of younger pedigree, had less rigorous requirements. 
There are only four published papers from Johnson's undergraduate and graduate ethnographic work, three of which are short notes on tribes in the Indian Notes on the Museum of the American Indian. ${ }^{57}$ The most substantial of the four, Johnson's "Notes on MicMac Shamanism," published in Primitive Man, relied on data collected during the summer of 1930, when Johnson lived on a Micmac reservation in Nova Scotia. Though published during World War II, thirteen years after the completion of the fieldwork and after Johnson's interests shifted to archaeological theory, his published account of his work among the Micmac is entirely ethnographical in its preoccupations with linguistics, analysis of taboo, myth, and societal ordering. ${ }^{58}$ Johnson's article continued to reflect many of the conventions of early twentieth century ethnology even as ethnological theory faced revision - he wrote, for example, of the impossibility of separating "the extraneous (postcolonial European) and indigenous sources" in shamanist practices. Embedded in this structuring of Johnson's analysis was the sense of urgency in regard to post-colonial cultural loss that notably had promoted much of the century's ethnological studies. ${ }^{59}$ It is the last paper Johnson published which exhibits a great emphasis on ethnological data.

\section{The Development of Americanist Archaeology}

Johnson's adolescent and young adult interests in ethnographic work reflects the

\footnotetext{
${ }^{45}$ Richard S. MacNeish, “Obituary: Frederick Johnson,” 269-270. Johnson published a short piece the year of graduation - a list of children's nursery rhymes from New England without commentary. See Frederick Johnson, “More Children’ Jumping Rhymes," The Journal of American Folklore 42, no. 165 (1929): 305-306.

${ }^{58}$ Frederick Johnson “Notes on Minmac Shamanism,” Primitive Man 16, no. 3/4 (1943): 53-80.

59 Johnson, "Notes on Shamanism," 53-54. Interestingly, Johnson thanks Speck in the first endnote "for consultation during the final preparation of the manuscript."
} 
period's preoccupations in a manner like that of a prism: American archaeology had functioned as a lesser cousin to ethnology for much of the first three decades of the twentieth century. Similarly, Johnson's 1930s transformation into a professional archaeologist coincides with the development of Americanist archaeology separate from ethnology. Johnson's career spanned a period of rapid growth in professional archaeology in the United States.

Archaeologist Robert Dunnell argued that as late as 1935, "the number of professional archaeologists was so small that most knew each other first hand."60 In contrast, Johnson's own correspondence of the early 1950s reveals that only fifteen years after Dunnell's comments, the situation had changed greatly. The change reflects an increase in Americanist archaeologists who required avenues of communication and resulted in the newsletters, journal, and conferences of the SAA. American archaeological practice grew enormously within in the period 1930-1950, spurred by an influx of federal funding, convergent regional taxonomic systems and chronologies, and the development of the administrative capacities of professional organizations.

Up to and perhaps through the New Deal era, Americanist archaeology functioned as a regionally oriented endeavor. ${ }^{61}$ (This is not to argue that there is no longer a regionally oriented component to American archaeology, only to denote a twentieth century move

\footnotetext{
${ }^{60}$ Robert C. Dunnell, "Five Decades of American Archaeology," in American Archaeology Past and Future: A Celebration of the Society for American Archaeology 1935-1985 (Washington, Smithsonian Institute Press, 1986), 23.

${ }^{61}$ The utility of separating the vast expanses of the U.S. into regions did not end with the New Deal era. For example, the river Basin Surveys project, an archaeological survey of America's river systems, beginning in 1945, delineated the country regionally, around water systems. Well published practitioners like Waldo Wedel (Lincoln office) and Franklin Fenenga (Berkeley office) directed fieldwork from regionally offices. See, Jesse D. Jennings, "River Basin Surveys: Origins, Operations, and Results, 1945-1969," American Antiquity 50 (1985): 281-196.
} 
towards greater collaboration amongst regional practitioners.) The lack of consensus illustrated by regional practice manifest itself in a number of ways. Differing theoretical contentions and related field practices precipitated a lack of interest in inter-regional cultural diffusion, chronological relationships, and cultural sharing: i.e., archaeologists who worked in sites in the American Southwest had little relationship with those working on Midwest mound builder societies. This state of affairs set American archaeological practice at odds with European and Middle Eastern archaeology, where "systematic attempts to construct links between early civilizations," began in earnest with Oskar Montelius's turn of the twentieth century work, and dominated practice. ${ }^{62}$ In turn, regionality facilitated hierarchies of practice, meaning differing areas of the country boasted distinguished practitioners who espoused separate methodologies; leaders included Alfred Kidder in the Southwest, Carl Guthe in the Midwest, and Franklin Fenenga in California. Practice was disparate enough that the years 1927 to 1939 saw the development of three competing taxonomic systems in the United States, each largely representing the findings and concerns of separate regional practitioners, one of which espoused a complete lack of interest in chronological concerns. ${ }^{63}$ Even with two chronologically oriented taxonomic systems, there remained through the 1930s a lesser interest in the chronology of American sites then that of sites in Europe and the Middle East. European and Middle Eastern archaeologists had an advantage over Americanist when it came to chronological schema-namely, written records from several

\footnotetext{
${ }^{62}$ Stuart Fleming, Dating in Archaeology: A Guide to Scientific Techniques (London: J.M. Dent and Sons, 1976), 15.

${ }^{63}$ B.K. Swartz Jr., "The McKern 'Taxonomic' System and Archaeological Culture Classification in the Midwestern United States: A History and Evaluation," Bulletin of the History of Archaeology 6, no. 1 (1996), 1. The three competing systems were Alfred Kidder's Southwest Pecos Classification, HeizerFenega's Central California Classification, and W. C. McKern's Midwestern Taxonomic system. The McKern system was curious in that it was taxonomic in a Linnaean sense and uninterested in chronological concerns.
} 
societies (Greek, Phoenician, Egyptian, among others), which could be dated back upwards of five thousand years. ${ }^{64}$ These written records, and their timely coordination with ancient astronomical events, provided the basis for absolute chronologies (those connected to calendar dates). These dates, in coordination with changes in technological culture, and in further coordination with the ample trade of Mediterranean civilizations, had allowed for Middle Eastern and European Archaeology to postulate complex date systems for the entire region, and for much of Europe. ${ }^{65}$ With the absence of written materials in the Americas, particularly in North America, no such absolute chronologies were possible. ${ }^{66}$ This reality in itself had not hindered the possibility of establishing relative chronologies (those that do not include calendar dates) based in stratigraphic digging in the Americas, yet little stratigraphy was in practice for numerous, sometimes conflicting reasons, until the development of a context in which chronology was a dominant concern.

The potential utility of archaeological chronologies was informed by developments in ethnology. Ethnologists worked in the first decades of the century to develop firmer understandings of distinctions amongst tribal cultures and this led many to postulate diverse

${ }^{64}$ Colin Renfrew, Before Civilization, 26-37. The correspondence of Egyptian king lists and astronomical Sothic cycle (return of Sirius the Dog star) put the oldest calendar date at 1872 B.C. during the reign of Sesostris III. The work to establish these chronologies was begun by Egyptologists in the late nineteenth century, culminating in the Eduard Meyer's Agyptische Chronologie in 1904. See Marshall Clagett, Ancient Egyptian Science: Calendars, Clocks, and Astronomy (Philadelphia: American Philosophical Society, 1989), 195, and also William C Hayes, "Egypt-To End of Twentieth Dynasty," in Chronology (Cambridge: Cambridge University Press, 1964), 21-24.

${ }^{65}$ The Egyptian chronology, when utilized to corroborate dates with pottery technology changes and other cultural developments, and therefore connected to stratigraphic finds of Egyptian products throughout the Mediterranean, provided a solid basis for chronologies throughout the region, and even Europe (where Roman finds provided the center-line for chronologies). See Colin Renfrew, Before Civilization, 28-47, and Stuart Fleming, 15-28.

${ }^{66}$ Colin Renfrew, Before Civilization, 20-47. There were, of course, Mayan hieroglyphs, though Tatiana Proskouriakoff largely deciphered these at a later date (late 1950s-early 1960s). Incan braided ropes have also, in recent years, been noted to contain information, perhaps even a largely un-deciphered system of records. See Matthew Hedman, The Age of Everything: How Science Explores the Past (Chicago: The University of Chicago Press, 2007), 7-25. 
origins of technology and cultural tropes amongst tribes. A developing theory of cultural borrowing or sharing (of technology, language, and other cultural traits) in turn led to questions regarding tribal migration and therefore the need to delineate historic movements. These questions of cultural "diffusion" were not directly germane to ethnological practice and instead came to dominate archaeologist's concerns. Culture history practitioners like A. L. Kroeber and Clark Wissler, in particular, developed complex theories of historical migration. ${ }^{67}$ Similarly, at this time European archaeologists had begun to question unilateral conception of cultural and technological progress (models of universally shared "stages" of progress) and this too influenced Americanist practice. ${ }^{68}$ Developments in theory and technique slowly placed emphasis on exhumed finds in North America. Stratigraphy, for example, did begin to produce results related to human population migrationary patterns in digs in Peru, California, Mexico, and the American Southwest. Dendrochronology also began to reveal calendar dates for sites in the Southwest in the 1930s. ${ }^{69}$

But perhaps just as significant for the development of Americanist archaeological practice were principle changes in the relationship of archaeology to academic institutions and the funding apparatus of the federal government in the period after World War I. Anthologist Thomas C. Patterson points to the "crystallization of a national science policy out of various earlier strands" in the post-World War I era as having had a specific and lasting effect in promoting archaeological practice. ${ }^{70}$ Patterson characterizes emerging government funding and interest in archaeology as part of a heritage oriented nationalistic

\footnotetext{
${ }^{67}$ R. Lee Lyman, Michael J. O’Brien, and Robert C. Dunnell, Culture History, 18. Trigger, “American Indian," 666-667.

68 Trigger “American Indian,” 666.

${ }^{69}$ Robert C. Dunnell, “Five Decades,” 26.

70 Thomas C. Patterson, "The Last Sixty Years,"10.
} 
enterprise, which developed archaeological sites as tourist attractions. Collaborating Patterson's position is the fact that the "National Academy of Sciences established the Division of Anthropology and Psychology within the National Research Council" in the period immediately after WWI. ${ }^{71}$ Echoing Patterson, Paul Fagette, who traces the roots of institutional American archaeology, notes the 1930s lack of federal interest in archaeology's late nineteenth century institutions — museums, private societies, universities — and the subsequent rise of interest in field archaeology under the auspices of the government's largescale federal projects. ${ }^{72}$ Similarly, philanthropic organizations, such as the Rockefeller and Carnegie Foundations, began funding archaeology under the auspices of a greater attempt to fund American sciences, but also as part of a nationalistic or even hemisphere-specific attempt at competition with European science and industry. ${ }^{73}$ These developments led to large-scale projects, inter-organizational collaboration, and an opportunity for professional organizations to provide administrative direction and norms of practice for fieldwork. Essentially, Fagette and Patterson tie the professionalization of archaeology to the large-scale economic and social change of the 1930s, including_in Fagette's case-important New Deal legislation. Furthermore, both authors point to the large-scale growth of American academic institutions in the period, and therefore the growth of archaeological labs and practice in anthropology departments.

In all, changes in theory surrounding the time-scale of Indian presence on the continent and the nature of tribal cultures in the Americas, coincided with changes to the

${ }^{71}$ Fred Wendorf and Raymond H. Thompson, "The Committee for the Recovery of Archaeological Remains: Three Decades of Service to the Archaeological Profession," American Antiquity 67, no. 2 (2002) 318.

\footnotetext{
${ }^{72}$ Paul Fagette, Digging for Dollars, XVII.

73 Thomas C. Patterson, “The Last Sixty Years,” 10-11.
} 
academic and bureaucratic apparatus of American Archaeology and culminated in the rapid, large-scale development of the sub-discipline. R. Lee Lyman, Michael J. O’Brien, and Robert C. Dunnell, in their discussion of the rise of the "culture history" during the 1930s, observe that Americanist archaeology had remained without professional archaeologists, established field methods, educational programs, or data through the late nineteenth century. ${ }^{74}$ The authors suggest that, "the analytical tenets, or principles, underlying the various methods and techniques were formalized and axiomatized in later years such that by the 1930s they constituted the first formal paradigm in Americanist archaeology.",75

\section{Johnson and Archaeology}

Beginning in 1930 Johnson worked as a graduate student at Harvard, and soon held a position in the Peabody Museum. His shift from the University of Pennsylvania had a number of important outcomes: Johnson was finally separated from his long time mentor Speck, he was closer to his family home in Everett (a mere five miles away), and he found himself at a university whose program had long displayed Frederic Ward Putnam's emphasis on archaeological practice and not Boasian ethnology. ${ }^{76}$ It is perhaps not possible to discern the exact motivation of Johnson's shift from one Ivy League institution to another; it is just as likely either that his deeper interest in archaeology predated the move or that it was simply informed by it. Perhaps the rigorous University of Pennsylvania anthropology program and

${ }^{74}$ R. Lee Lyman and Michael J. O’Brien, Culture History, 13.

${ }^{75}$ R. Lee Lyman and Michael J. O’Brien, Culture History, V.

${ }^{76}$ Marilyn Norcini also pointed out the differing emphases of the University of Pennsylvania (that of ethnology and linguistics) and of Harvard (that of archaeology) in the period. 
the fact that Speck was "insistent that his students publish," were at the heart of Johnson's move to Harvard and/or at the crux of his academic difficulties at the University of Pennsylvania. ${ }^{77}$ Either way, the physical shift of Johnson from University of Pennsylvania to Harvard signaled both a change from ethnology to archaeology and a shift in Johnson's professional allegiances. Further evidence of Johnson's recognition of the gravity of the shift towards archaeology is Johnson's late in life dismissal of his ethnological reports as “quite naive," and his opinion that, "it is better to let them lie obscurely in dusty volumes.",78 Eschewing any sense that Johnson's poor performance at the University of Pennsylvania had hindered him he was made a Hemingway Fellow at Harvard in 1930. Just as during his undergraduate studies, Johnson again quickly took to the field. From 1931 to 1933 Johnson had the opportunity to serve as assistant to Samuel K. Northrop for excavations at the Sitio Conte site in Panama. Despite Johnson's obituary writer Macniesh's implication that Johnson braved "tropical diseases, poisonous snakes, pestilential insects, and often hostile Indians," the dig site was not a deep jungle site but was privately held by a cattle ranching family, was situated along the Rio Grande River, and was funded by the Harvard Peabody Museum. ${ }^{79}$ Johnson continued to exhibit some interest in ethnological work while in Mesoamerica but generally the work in Panama was archaeological in nature; the rich funerary site was the source of much gold and precious metal artifacts and, along with Mayan and Aztec ruins, was one of the places in the Western hemisphere where the rich finds led to the consensus there that archaeological matters trumped ethnological ones. Despite the

\footnotetext{
${ }^{77}$ Norcini, “River Desert Algonquin,” 125.

${ }^{78}$ Norcini, "Canadian Ethnology," 116. Norcini has quoted this from "Johnson ca. 1975, Biographical details, Tufts University archives."

${ }^{79}$ Richard S. MacNeish, “Obituary: Frederick Johnson,” 270-280.
} 
emphasis on archaeology at Harvard, archaeological field methods remained haphazard. For example, Olga F. Linares in her description of the site notes that stratigraphy was seldom utilized by the Harvard team, and was eschewed in the interest of expediency, and in line with a continuing disinterest in chronology. ${ }^{80}$ Even with the new chronological contentions of "culture history," a continuance of the "object centered approach" which focused upon the building of artifact collections was manifest in both Harvard and the University of Pennsylvania's work related to acquisitions for university museums. ${ }^{81}$

In 1933 Johnson returned to the United States to take graduate classes at Harvard. He was hired as an assistant in the anthropology department and did curatorial work for the university's museum. That summer he went to the Yucatan and participated in the massive, well-funded Carnegie digs of Mayan sites. It was apparently Johnson's first experience with a large well-funded dig that employed a multidisciplinary approach. The model did not particularly impress Johnson; perhaps it differed too greatly from the self-reliant nature of ethnological fieldwork. ${ }^{82}$

Upon return he was hired as a part time instructor in the anthropology department though he had not finished his Ph.D. In a career dominated by administrative interests and curatorial work, this would appear to have been his only official teaching position. It was short lived; Johnson did not finish his Ph.D. (he was "all but dissertation" at Harvard), and this, connected with his lack of publications, presumably left him out for the running for

\footnotetext{
${ }^{80}$ Olga F. Linares, Ecology and the Arts in Ancient Panama: On the Development of Social Rank and Symbolism in the Central Provinces (Washington D.C., Dumbarton Oaks, 1977), 34.

${ }^{81}$ Marilyn Norcini, "Canadian ethnography," 110. The University of Pennsylvania sponsored a dig at the site in 1940, and a large collection of artifacts from the site is still housed at the Penn Museum. See "River of Gold, Pre-Columbian treasures from Sitio Conte. http://www.penn.museum/travelingexhibits/351-river-of-gold.html, accessed March 4, 2010.

${ }^{82}$ Richard S. MacNeish, “Obituary: Frederick Johnson,” 270.
} 
more permanent academic appointments. Instead, other avenues within the field had developed, in part due to the continued large-scale professionalization of Americanist archaeology occurring at the time. In 1936 the director of the Peabody Institute, Douglas Byers, appointed Johnson curator of the small Peabody collection at the Phillips Institute at Andover. Johnson and Byers would work in close quarters with one another for the next twenty years and co-write a number of articles (when Johnson did publish it was very often in collaboration). The curatorship left Johnson with ample time to pursue field pursuits, particularly those centered along the Eastern seaboard. Johnson essentially pursued two main interests within the discipline in the ensuing years: he continued field work with an emphasis on the management of large scale, multidisciplinary projects, and he developed administrative positions as an bureaucratic member of Americanist archaeology's largest professional organizations.

In terms of professional organizations this meant that Johnson would readily fill an administrative post, often those with less leadership duties than administrative ones, positions like "treasurer," or "executive secretary." In the course of his career he would serve in important administrative capacities in both the SAA and the AAA, becoming treasurer of the SAA (1943), president of the SAA (1947-1948), Chair of SAA planning committee (19441952), secretary of the influential Committee for the Recovery of Archaeological Remains (CRAR) (1945-1956). He would likewise become second executive secretary of the AAA (1949-1952), chair of the AAA committee-CRC14, (1948-1952), and editor of “Archaeological News, Western Hemisphere," of the Archaeological Institute of America's American Journal of Archaeology. This appointment, in particular, testified to Johnson's ubiquitous presence in archaeological organizations because the journal's long-standing emphasis on the archaeology of Europe and the Middle East left little room for Americanists 
in formal positions. ${ }^{83}$ Johnson did not simply hold these positions, but in many cases expanded the authority of the position and the organization, as he did while chair of the CRC14. For example, in the case of his position as executive secretary for the AAA, he was credited with "the expansion and development" of the position, during the AAA's post-war membership boom. ${ }^{84}$

In relation to fieldwork Johnson's administrative leanings meant that he would assemble teams of archaeologists (and in some cases botanists and other specialists), solicit funding for the digs, and then was content to allow the archaeologists involved write their papers and reports individually, often taking the reins in having these published in a single volume (in which he would write the introduction). Johnson's large project of the period exemplifies the trend in administrative field research discussed above. Johnson organized an interdisciplinary dig of an ancient fish-weir found under a Boston street. The dig signaled a shift from ethnological and archaeological interests abroad to archaeological interests close in the vicinity of his curatorship. The project began in 1939 and involved 15 different scientists from various scientific professions, and was assisted by The New England Mutual Life Insurance Company (which owned the site) and the Turner Construction Company (which provided the large-scale digging). ${ }^{85}$ Johnson, unhappy with the methodologies he witnessed in the Carnegie dig in South America, developed a variation on the interdisciplinary collaboration his obituary writer discusses as a "major breakthrough in American

${ }^{83}$ Although some may point to the existence of published articles in the journal that discuss American sites, the distinction is widely accepted. See Colin Renfrew, "The Great Tradition."

${ }^{84}$ Frederick Johnson, “Anthropological Professional Associations,” Yearbook of Anthropology (1955), 435.

${ }^{85}$ Frederick Johnson, et al., The Boylston Street Fishweir (Andover: Phillips Academy Foundation, 1942), xi. 
archaeology," one that informed modern inter-disciplinary practice. ${ }^{86}$ Essentially, Johnson did not assign specialists of divergent fields (botany, anthropology, archaeology) to different tasks, but required each to examine the same question. In the case of the fishweir, Johnson proposed they examine, "how humans changed the environment in the Boylston Street area." 87

Johnson also helped Byers manage a number of Phillips Academy sponsored summer digs in the late 1930s throughout New England that utilized Phillips Academy students. Therefore, though Johnson did not spend time teaching in the classroom, he "trained the 'boys"' in the field and participated in a number of digs. His interdisciplinary work continued on two expeditions to the Yukon (1944 and 1948) with botanist Hugh Raup. ${ }^{88}$ Throughout the period “Johnson's achievements were tempered by criticism from some of his contemporaries for his minor production of academic publications in comparison to the participants in the large scale interdisciplinary projects that he managed." 89 The criticism reflected the reality that Johnson's postwar publications generally included little personally developed research; his articles were often summaries of the year's archaeological points of interest, or editorials (in his capacity as editor of a professional journal), or short summaries of work accomplished in the field by he and a number of other specialists. When he did publish other types of articles they were with few exceptions short, and in some cases they were co-written with one or more other archaeologists.

Yet this criticism ignores the development of complex hierarchies in the sciences

${ }^{86}$ MacNeish, “Obituary: Frederick Johnson,” 270.

${ }^{87}$ MacNeish, “Obituary: Frederick Johnson,” 270.

${ }^{88}$ Frederick Johnson, “An Archaeological Survey Along the Alaska Highway, 1944,” American Antiquity, Vol. 11, no 3 (1946), 183-186. Obit 270

${ }^{89}$ Marilyn Norcini, "Canadian Ethnography," 107. 
prompted by growth and changes in Americanist archaeology. Criticism was perhaps a

reaction to the sudden power and prestige of individuals who chose an administrative career path instead of the older and more formalized career in academia. In Johnson's case, the founding of the Society for American Archaeology, December 28, 1934, greatly impacted the course of Johnson's career by providing a non-academic bureaucracy that served Americanist archaeology. The professional organization's development speaks to the advancements of Americanist archaeology as a separate discipline, requiring an institution with separate goals from that of the older and more broadly diverse American Anthropological Association (AAA) and the older Archaeological Institute of America (AIA). ${ }^{90}$ Though Johnson's name would not be on the charter constitution of 1935 , he would soon be a new member to the SAA and he would read a paper during the second annual meeting of the organization in $1936 .{ }^{91}$

Johnson's positions in the SAA and AAA (as well as with other professional organizations) allowed him to publish administrative notes regularly in organizational journals, and gain editorship in certain cases. Johnson's position as treasurer of the SAA

\footnotetext{
${ }^{90}$ The American Anthropological Association's deliberations began in the fall of 1901 and the organization was officially begun in March 26, 1902. The flagship publication American Anthropologist was a joint venture of Franz Boas and W. J. McGee begun in 1899. It is instructive to note the reasons why archaeologists developed own organization, separate from the AAA. The AAA had broadly defined interests, and roots in Boas and an ethnological bend in Anthropology—archaeologists and their discipline was but a small part of the association. But the immediate impetus for the development of the SAA was the change of editorial ship of American Anthropologist in 1933 that meant that the journal would "no longer include annual summaries of archaeological activities." During the December meeting of the AAA archaeologists away from the proceedings discussed the creation of a new archaeological organization. Like the AAA the SAA would admit amateurs, in part, in Guthe's words because of the need for dues (i.e. the small number of professional archaeologists working at the time). The first annual meeting of SAA December 1935. See L.G. Moses, The Indian Man: A Biography of James Mooney, (Lincoln: University of Nebraska Press, 2002): 137. See also "The American Anthropological Society: Antecedent Conditions" New Series, American Anthropologist 5, no. 1 (1903), 179-181 and Carl Guthe "Reflections on the Founding of the Society for American Archaeology," American Antiquity 32, no. 4 (1967): 262-267.

${ }^{91}$ Frederick Johnson, "Problems Surrounding the Classification of Certain Culture Complexes in New England," American Antiquity 3, no.2 (1937): 161-165. This paper was "delivered before the S.A.A," Washington, Dec. 29, 1936.
} 
meant that he was from time to time called upon to give brief notices in American Antiquity, related to news about the organization's details of operation..$^{92}$ Johnson time as the editor for “Archaeological News, Western Hemisphere," in the American Journal of Archaeology allowed him to include a yearly "Archaeological News" short article, which summed up the year's finds and developments in American archaeology. Similarly, Johnson was editor of the AAA's quarterly bulletin from 1949 to 1954 and therefore accomplished many of the same tasks for that institution.

During the period, when Johnson did publish (outside of his administrative writing in professional journals), he tended to write articles about the professionalization of the discipline. The rise of popular interest in American archaeological sites, and the ensuing growth of regional archaeological societies populated by enthusiastic amateur collectors, meant that Johnson felt he should turn his attention to the education of amateurs. For example, Johnson's and Douglas Byers’s 1938 article “The Purchase of Archaeological Material," addresses the need for those interested in archaeological science to be aware of the importance of context in shaping scientific knowledge of finds. They state that, "collecting artifacts with no regard for their situation and association is analogous to tearing pages out of books."93 In the same year Byers's and Johnson's paper "Some Methods Used in the excavation of Shell Heaps," began with the statement, "this paper is intended as an aid for those conscientious amateur archaeologists who are interested in preserving their specimens and the data which goes along with them." ${ }^{94}$ The essay described proper stratigraphic

92 See Frederick Johnson, “Editorial,” American Antiquity 9, no. 2 (1943), 161.

93 Douglas S. Byers and Frederick Johnson, "The Purchase of Archaeological Material," American Antiquity 4, no. 1 (1938): 62. 
techniques, avoiding deeply technical explanation or terminology, and reflected Johnson's growing interest in the management of amateur action in the field. ${ }^{95}$

Yet just as important to Johnson was the further development of professional organizations, which he argued when properly employed would assist members "in all phases of their work." Johnson's promotion of professional organizations was predicated upon his awareness of large scale progress in the development of Americanist archaeology, expressed in the necessity for the development of an American archaeology specific organization (the SAA) and large scale growth of both the SAA and AAA membership in the postwar period. Johnson was also aware of larger trends in postwar science, and perhaps even felt the challenge of the funding gap between the social and physical sciences. In an article entitled “Anthropological Professional Associations," he stated:

Anthropologists as a group resist formal organization other than that barely necessary to permit restricted publication and some scientific meetings. The present trend in the scientific community at large appears toward the organization of professional associations.... There is a need of such an association in anthropology both for use of the members and for uniting, but not submerging, the wide variety of specialized societies in order to form an organized whole. In the United States the American Anthropological Association has assumed a certain amount of leadership. ${ }^{96}$

Johnson's high opinion of professional organizations and the need for structured development of the anthropological sciences would grow and inform much of his decisions in regard to the development of carbon-14 dating.

94 Douglas Byers and Frederick Johnson, "Some Methods Used in Excavating Eastern Shell Heaps," American Antiquity 4, no. 3 (1939): 189

${ }^{95}$ It is interesting to note the relevance of amateur practitioners to archaeology in the twentieth century, verse their greatly diminished statue in other scientific disciplines.

${ }^{96}$ Frederick Johnson, “Anthropological Professional Associations,” Yearbook of Anthropology (1955): 439. Though this article was written in the mid-fifties, it clearly outlines much of Johnson's longstanding positions on the importance of professional organizations. 


\section{Johnson's Development of the CRAR}

Frederick Johnson was in Washington D.C. during World War II. Most archaeological work was put on hold during the war, and Johnson worked those years for the Navy, and fostered a relationship with Smithsonian archaeologists. His relationship with

Julian H. Steward of the Smithsonian was such that Johnson assisted Steward with the editing and authorship of Steward's Handbook of South American Indians. Many of the archaeologists and anthropologists Johnson collaborated with in this period would serve with him on the influential Committee for the Recovery of Archaeological Remains (CRAR).

Though it was not possible during the war years to find time or funds to attempt large-scale archaeology projects, there was ample time to discuss plans for a more structured postwar federal archaeology. Wendorf and Thompson describe Smithsonian archaeologists Frank H. H. Roberts, Frank M. Setzler, anthropologist Julian H. Steward, and Frederick Johnson as the "Washington group," of which Johnson was a "key member."97 The group's discussions about archaeology frequently turned to issues of government policy and the discontinued archaeology of the CCC and WPA. The period no doubt informed Johnson's conceptions of the bureaucracy connected to government funding, and of wartime growth of government funding. For example, despite the promise of funding opportunities, by war's end Johnson was wary of federal bureaucracy, noting the "red tape," of institutions like the NRC. Of the NRC, Johnson expressed that "things get lost (there) and when action is required it is sometimes difficult to avoid entanglements." 98 This distrust and sense of mismanagement of public institutions informed his interest in professional organizations and

\footnotetext{
${ }^{97}$ Wendorf and Thompson, 319.

98 Johnson, quoted in Marlowe, "Year One," 21.
} 
provides insight into Johnson's own position in the debate concerning the postwar restructuring of the sciences. ${ }^{99}$ Essentially, Johnson did not eschew the administrative and bureaucratic necessities of big science, but idealized models related to private enterprise, and not the public sector. For example, in a discussion of necessary training for young archaeologists, Johnson professed that a candidate should be taught to "handle administrative and labor problems" and "should be prepared to discharge his duties completely and efficiently in much the same way as a small business is run."100

Despite Johnson's concerns about government bureaucracy, he expressed the hope that there could "be instituted in the federal government an efficient administration that would allow archaeologists to conduct their research in the field and laboratory according to recognized standards." ${ }^{101}$ In support of such a program, Johnson and the other Smithsonian archaeologists met often and planned for postwar practice, and Johnson describes “discussions, machinations, and political maneuverings that began, certainly as early as 1942."102 Due to their proximity and dealings with government agencies in Washington, they became aware that the Army Corps of Engineers planned numerous large-scale dam projects for the period after the war. Johnson and the others members bemoaned much of the poor quality archaeological work done in the previous decade in the name of WPA archaeology, and therefore sought to rectify the situation in the coming decades with a more organized

\footnotetext{
${ }^{99}$ Marlowe, "Year One," 21. Johnson expresses a similar opinion, expressing a worry about "red tape" in the letter Johnson to Fejos, December 22, 1947, FJP.

${ }^{100}$ J.O. Brew, et al. "Symposium on River Valley Archaeology,” 215. Each commentator in this article had a separate section for comments. The quote falls in Johnson's area of the article.

${ }^{101}$ Johnson, reminiscence, 1976:8, ASMA, as quoted in Wendorf and Thompson, 319.

${ }^{102}$ Wendorf and Thompson, 320.
} 
archaeological response to federal projects. ${ }^{103}$ Johnson's and other Washington

archaeologist's complaints about pre-war archaeology may be noted as instructed by wartime changes to science administration, and an interest in aligning archaeology with these developments.

Johnson was the first of the Washington group to attempt to create a bureaucratic structure that would facilitate the development of standardized postwar practice. At the May 1944 meeting of the SAA he suggested that the SAA create a committee that was a counterpart to the Basic Needs Committee of the NRC. The SAA formed the Planning Committee and Johnson was made chair. ${ }^{104}$ Wendorf and Thompson outline Johnson's adept maneuverings as chair of the committee, and explain that he chose members strategically and consolidated power so that he could act independently and avoid conflict with the NRC. ${ }^{105}$ Johnson was able to secure a grant from a New York based anthropology philanthropic, the Viking Fund, for Planning Committee work. ${ }^{106}$ (His relationship to this organization, and its director Paul Fejos would be of use as Johnson would later seek funding for carbon-14 dating.)

${ }^{103}$ Wendorf and Thompson, 319-320.

${ }^{104}$ The committee makeup reflected the regional diversity of the SAA: it was Frederick Johnson, James B. Griffin of the University of Michigan, and Emil W. Haury of the University of Arizona. The committee was created by SAA president J. Alden Mason, who was curator of the University Museum at the University of Pennsylvania during Johnson's time there as a student, and who had worked closely with Johnson, notably Johnson had assisted Mason in writing some of the entries for Mason's Handbook of South American Indians. See American Philosophical Society, "background note," John Alden Mason Papers 1904-1967. http://amphilsoc.org/mole/view?docId= ead/Mss.B.M384-ead.xml\#bioghist. Also, Wendorf and Thompson, 320.

${ }^{105}$ Wendorf and Thompson, 320.

106 The Viking Fund was a philanthropic based in New York, New York that specialized in funding innovative anthropology and archaeology projects. It was administered by Hungarian born medical doctor, amateur anthropologist, and Hollywood filmmaker Paul Fejos. The philanthropic would become the main source of funding for The CRC14 and for Libby's testing of carbon-14 dating. For a larger discussion of the Viking Fund see Appendix B. 
Johnson developed the Committee for the Recovery of Archaeological Remains (CRAR) out of the Planning Committee in 1945. In his own words in a letter to colleague John Otis "Jo" Brew, Johnson described the development of the committee stating, "after a year or more of machination, I . . formed CRAR, rigged the membership to satisfy some political requirements, got you on the scene, and then went to town." ${ }^{107}$ The CRAR would focus on salvage archaeology around the over 100 federal dam projects. It would lobby for government action in regard to the destruction of important archaeological sites, and facilitate the creation of the River Basins Surveys, a large scale federally funded program under the Bureau of American Ethnology. Most importantly, it would allow Johnson and other Americanist archaeologists to lobby the government for funding of projects they deemed imperative for preservation of the archaeological record.

In the prewar period, only William Webb's salvage archaeology, done in relation to Tennessee Valley Authority dams, stood out as having employed acceptable methods, and it therefore became the working model for postwar river surveys. ${ }^{108}$ Using Webb's work as the model, the CRAR instructed the course of salvage work. It also continued to lobby the government for continued awareness of the importance of archaeological projects; the CRAR published a resolution in the July 1945 Science arguing for the need for a Federal law which mandated "adequate conservation of archaeological resources" during any federal river basin engineering project. The resolution, signed by Johnson, Duncan Strong and William Webb,

${ }^{107}$ Wendorf and Thompson, 321, quoting Johnson to J. O. Brew, 1973.

108 Salvage archaeology is done when construction or other great change threatens to disturb or destroy sites that have not yet been studied by archaeologists. The building of dams often acts as a catalyst for salvage archaeology due to the fact that ancient cultures often lived along the banks of waterways. William Webb was chair of both the Department of Physics at the University of Kentucky, and the Department of Anthropology. His training was in physics, making him, like Johnson, a twentieth century archaeologist without anthropology Ph.D. credentials. For a discussion of him and TVA salvage archaeology's effect on the postwar River Basin Surveys, see Wendorf and Thompson, 318-319. 
was rhetorically consistent with wartime tropes of national interest, expressing American sites as part of an "utterly unique American historical record," and pointing to such assets as "belonging to the entire nation.", 109

The CRAR also simultaneously endeavored to inform the public of the need for salvage archaeology. Wendorf and Thompson point to the plethora of material printed for the public created by the CRAR (press releases, brochures, etc.) as well as the lectures and public events as an important factor in the rising awareness of the scientific and cultural importance of archaeological sites in the postwar period. In fact, the historians note that the CRAR's postwar work may indeed be "the basis for our modern cultural preservation efforts." 110

Johnson therefore had positioned himself as an important player in the administration of Americanist archaeology in the postwar era despite his tenuous relationship with academic archaeology. The CRAR had developed from a loose association of archaeologists employed at different organizations to become a cohesive body that could affect national policy, all under the auspices of a professional organization. Individuals concerned with questions of chronology and cultural diffusion gradually also came together to attempt to standardize field methods and practice. Much of this work done within the newly formed organization the SAA, unlike the work of earlier organizations, served American archaeology specifically and solely. Johnson therefore became an important member of the SAA: as a general member, as

\footnotetext{
109 Duncan Strong, Frederick Johnson, and William S. Webb, "National Archaeological Resources," Science 102 (1945), 44.

${ }^{110}$ Wendorf and Thompson, 318. Marlow, "Year One," 17. Marlowe notes that despite not being chair of the CRAR, Johnson was the "real moving force on the CRAR," and also that the committee was "unquestionably the most respected one serving the cause of American Archaeology."
} 
head of the Planning Committee (which would remain active until 1952), and as acting force behind the CRAR.

The CRAR was, in Wendorf and Thompson's vision, “unquestionably the most respected one [association in the era] serving the cause of American archaeology." 111 It acted to fill a number of lacunae in Americanist archeology: it broadened the SAA's relationship with the federal government and particular federal government departments/agencies (U.S. Park service, the Smithsonian), it raised critical awareness of the large number of unexcavated American sites, and it simultaneously aided in the field training of a large portion of a generation of archaeologists in salvage methods and administration of large scale projects. Johnson's work with the CRAR would greatly inform Johnson's work with the CRC14.

${ }^{111}$ Greg Marlowe, "Year One," 17. 


\section{CHAPTER 2: WILLARD LIBBY}

Willard Libby's development of carbon-14 dating in the late 1940s precipitated one of the largest shifts in archaeological practice to date. His development of the method will be discussed in this chapter to provide context for a discussion of the CRC14.

Libby began his education in at the University of California-Berkeley, in the late 1920s and received his B.S. in 1931. He was the first graduate student accepted for Gilbert Lewis's new school of nuclear chemistry and received his Ph.D. in 1933. Working with Wendell Latimer he utilized the recently developed Geiger-Muller counter to test for "undiscovered radioactivity among the ordinary elements." ${ }^{112}$ Libby and Latimer's great distance from Europe meant that they were without a second generation, or "tube type" Geiger counter, so they built one of their own, which according to Libby's later recollection, was the first of its kind in the United States (the skill of building apparatuses that could detect weak radioactivity would serve Libby well in the development of carbon-14 dating). ${ }^{113}$ During this period, he and Latimer worked to discover naturally occurring radioactivity (artificial radioactivity would be discovered by Joliet-Curie in 1934), and therefore discovered natural radioactivity in samarium and in neodymium. Neither discovery resulted in acclaim because George von Hevesy published independent evidence and radioactivity in

\footnotetext{
${ }^{112}$ Willard Libby, U.S. Atomic Energy Commission "Chemistry and the Atomic Nucleus," Washington, D.C. (Washington D.C., 1958), 525.

${ }^{113}$ Willard Libby, "Chemistry and the Atomic Nucleus," 525.
} 
samarium before Libby and Wendell, and the radioactivity noted in neodymium was apparently a unique result that was never confirmed by later testing. ${ }^{114}$

Upon completing his Ph.D. in 1933 amidst the Great Depression, Libby was offered only two teaching jobs, a part-time position at a junior college, and a position working with his mentor and others at Berkeley. ${ }^{115}$ He stayed at Berkeley, becoming part of a department that included much of the American contingency of individuals interested in radioactivity and nuclear science: Sam Ruben (who would co-discover artificially produced carbon-14), Glenn Seaborg, Joe Kennedy, Art Wahl, Wendell Latimer, and Ernest Gibson. ${ }^{116}$ Also at Berkeley during Libby's tenure there—-though in Ernest Lawrence's physics laboratory—were Ernest Lawrence, Martin Kamen (co-discover of artificially produced carbon-14), and Robert Oppenheimer, among many others. ${ }^{117}$

While Libby was at Berkeley a number of discoveries were relayed to the department that revealed aspects of naturally occurring isotopes, and each can arguably be pointed to as a necessary precursor to Libby's dating process. News of the Joliot-Curie discovery of artificial radioactivity reached Libby's department particularly fast; the two cabled Ernest Lawrence at Berkeley soon after their discovery, and Lawrence immediately "found that his whole laboratory was full of artificial radioactivity." 118 That same year Franz Kurie

${ }^{114}$ Willard Libby, "Radioactivity of Ordinary Elements, especially Samarium and Neodymium: Method of Detection," (Ph.D. dissertation, Berkeley, 1933). The dissertation exhibits his earliest interest in naturally occurring isotopes.

${ }^{115}$ Arnold, 4.

${ }^{116}$ Libby gives much credit to Gilbert Lewis for training and working with a large portion of the early generation of nuclear scientists, noting his relation to Manhattan Project participants Harold Urey, Thorfin Hogness, Frank Spedding, Glenn Seaborg, and Joe Kennedy. Libby, “Atomic Nucleus," 527.

${ }^{117}$ George B. Kauffman, "In Memoriam Martin D. Kamen (1913-2002), Nuclear Scientist and Biochemist," Chem. Educator 7, (2002), 305. 
postulated the creation of carbon-14 through "The neutron bombardment on Nitrogen in a cloud chamber," though the results could not yet be verified because no counter yet existed sensitive enough to test his speculations. As Libby notes, it was not until 1939 that "Serge Korff and colleagues established that cosmic rays produced secondary neutrons when they floated counters up into the highest levels of the atmosphere." ${ }^{119}$ Furthermore, carbon-14, though postulated earlier, was not produced in a laboratory until Martin Kamen and Samuel Ruben did so in $1940 .{ }^{120}$ These and other 1930s developments were what Libby had in mind when he related his "indebtedness to several earlier investigators" when he was lauded for his carbon dating process. ${ }^{121}$

Clearly, some of these breakthroughs occurred only as a result of technological advances in detection techniques; each development of more sensitive equipment yielded new particle and isotope discoveries. For this reason, Libby was interested in more detailed readings, and in 1933 he developed the screen wall counter. The device was a modification of a Geiger counter in which a screen was inserted that would let the sample's radiation pass through to the counter, but would also allow for the switching of the position of the sample to facilitate calibration of the levels of background radiation. The device would prove most useful later in the development of carbon-14 dating.

${ }^{118}$ Libby, "Chemistry and the Atomic Nucleus," 526. Irene Curie was the daughter of Marie Curie, and Joliot her husband. They were jointly awarded the Nobel Prize for their discovery of artificial radioactivity in 1935 .

${ }^{119}$ Willard Libby, "Radiocarbon Dating," Science 133, no. 3453 (1961), 621. Even the discovery of cosmic radiation had been fairly recent. V. F. Hess discovered it in 1911. See Willard Libby, Radiocarbon Dating, 1.

${ }^{120}$ Kauffman, "Martin D. Kamen," 305. Before this event there was no proof that C-14 even occurred naturally, or in a lab. Kamen and Ruben came up with a 5730 half-life for carbon that was not far from Libby's later estimate.

${ }^{121}$ Taylor, Archaeological Perspective, 147-149. 


\section{Carbon-14 Dating, Government Research, and Basic Science}

Libby was at Columbia University from 1941 to 1945 to work on the Manhattan Project. He worked to separate uraniuium-235 from bulk uranium, an important part of the process of developing the bomb. Furthermore, the process involved gaseous diffusion, which would inform Libby's sample preparation for carbon-14 dating. ${ }^{122}$ Wartime work therefore related to Libby's earlier interests of natural isotope detection, with the added twist of the need to separate and count isotopes for application within the context of the project. A further effect on Libby's postwar career trajectory was that Libby work on the Manhattan Project introduced him to 1934 Nobel Prize winning physicist Harold Urey at Princeton. ${ }^{123}$ Their solid working relationship and friendship no doubt was a factor in Libby being an early hire in Urey's newly formed department at the University of Chicago (the Institute of Nuclear Studies) immediately after the war. ${ }^{124}$

Like many scientists involved with the Manhattan Project, Libby's career trajectory and postwar scientific pursuits cannot be understood apart from the federal government's newly formalized relationship with all aspects of atomic science. Archaeologist R. E. Taylor has pointed to Libby's 1946 publication in Physical Review as the earliest postwar expression of Libby's interest in carbon-14, yet classified work Libby and Arnold did for Argonne labs that began in February of 1946 involved verifying the creation of carbon-14 through the

\section{${ }^{122}$ Arnold, 4.}

${ }^{123}$ Urey had studied under Gilbert Newton in the early 1920s, receiving his Ph.D. At Berkeley before going in 1923 to work Niels Bohr. He had shared Libby's interest in the dynamic field of natural isotope detection throughout the 1930s. See K. P. Chen, S. K. Runcorn, H. E. Suess, and H. G. Thode, "Harold Clayton Urey, 29 April 1893-5 January 1981," Biographical Memoirs of Fellows of the Royal Society 29 (1983), 628. and "Harold Clayton Urey" biography by James R. Arnold, Jacob Bigeleisen, and Clyde A. Hutchinson jr., at http://www.nap.edu/readingroom/books/biomems/hurey.html.

${ }^{124}$ Arnold, 4. 
continuous irradiation of Hanford's reactor's pile graphite. ${ }^{125}$ Arnold's and Libby's assertion in the formerly classified report of the existence of levels of carbon-14 useful for medical purposes, points to a shift in interests towards peacetime applications of atomic energy technology and the search for further domestic applications for atomic research biproducts. ${ }^{126}$ From February of 1946 until the fall of that year, they tested the spent graphite piles from Hanford and decided that they yielded significant amounts of carbon-14, with a level of "activity" that was "more than sufficient for most chemical problems and a wide variety of biological ones." Their conclusion therefore was that continued nuclear pile tests would produce "a quantity large enough to supply tracer carbon for many uses for the whole nation for years." 127 Germaine to a discussion of carbon-14 dating, to test the spent graphite Libby and Arnold would create "a technique for counting radioactive $\mathrm{CO} 2$ in the gas phase" which would be directly applied to the development of the dating method. ${ }^{128}$ Libby's appointment immediately after the war in 1945 to the University of Chicago's Institute for Nuclear Studies allowed him to moonlight for Argonne labs, and continue government sponsored nuclear research. Like most scientists with Manhattan Project experience, Libby

125 James Arnold and Willard Libby, "Radiocarbon from Pile Graphite; Chemical Methods for its Concentration," Argonne National Laboratory, Contract No. W-31-109-Eng-38 declassified Feb 16, 1957, (Office of Technical Services, Washington D. C. 1946), 7. R.E. Taylor has an slightly inaccurate chronology; he states that Arnold "since February 1946, had been working with Libby (not on C14 topics)..." In fact, Libby and Arnold began the experiment to establish the existence of carbon-14 in used reactor graphite in February, and therefore the research likely coincided with the earliest collaborations of the two men. See R. E. Taylor, Archaeological Perspective, 153. Libby's unclassified report of the year on radiocarbon was Willard F. Libby, "Atmospheric Helium thee and Radiocarbon from Cosmic Radiation," Physical Review, 69, no. 11-12 (1946), 671-672.

${ }^{126}$ The search for applications for Atomic testing byproducts began immediately after the war, long before the endeavor was institutionalized in Eisenhower's Atoms for Peace program in 1953. For a discussion of the Atoms for Peace program, see John Krige, "Atoms for Peace, Scientific Internationalism, and Scientific Intelligence," Osiris 21 (2006): 161-181.

${ }^{127}$ James Arnold and Willard F. Libby. "Radiocarbon from Pile Graphite; Chemical Methods for its Concentration," AEC contract no. W-31-109-Eng-38. (Washington, D.C.: GPO, 1946): 2.

${ }^{128}$ James Arnold and Willard Libby, “Radiocarbon from Pile Graphite,” 1. 
continued to do some work related to government contracts and sometimes worked directly for government agencies after the war. ${ }^{129}$

The evidence gleaned from the study of the graphite pile-that radiation would create carbon-14 from stable carbon (or perhaps other stable atoms, like nitrogen)—coincided with Libby's general interest in the process of isotope production (natural and artificial), and Libby theorized about the possibility of carbon-14 production occurring through the reaction of nitrogen with naturally occurring forms of radiation. This work culminated in his June 1946 Physical Review article "Atmospheric Helium Three and Radiocarbon from Cosmic Radiation" which postulated a manner in which carbon-14 may be created through the bombardment of high level atmospheric nitrogen by cosmic rays. Libby's thesis was not entirely without precedence-it was in fact a possible effect of cosmic radiation suggested by Serge Korff in $1939 .{ }^{130}$ In the context of the paper Libby also postulated that small amounts of carbon-14 would therefore be found in organic matter.

Libby's interest in carbon-14 must be understood in the context of the federal government's interest in peacetime nuclear technology applications (and funding avenues available to those willing to do isotope research) and the effect of their campaign on research. In 1945 the federal government began "elaborate public relations initiatives," employing exhibitions and road shows with titles like, "Main Street Meets the Atom," and "The AtomServant of Man," designed to create acceptance of nuclear bi-products by the general public. ${ }^{131}$ The government's public relations campaign found partners in the private sector,

\footnotetext{
${ }^{129}$ Libby, Radiocarbon Dating, v.

130 Willard F. Libby, “Atmospheric Helium Three and Radiocarbon from Cosmic Radiation,"
} Physical Review 69, no. 11-12 (1946): 671-672. Apparently Serge Korff had initially postulated the formation of radiocarbon at high altitudes. See Libby, "Radiocarbon Dating," Science, 621. 
most notably Libby's employer the University of Chicago. Both Leopold and Marlowe note the fact that Robert Hitchens, chancellor of the University of Chicago, was one of the earliest converts to the "power of the atom" and one of its greatest proponents, who engaged the federal government program in the hopes of promoting the University of Chicago's developing scientific departments. ${ }^{132}$ Echoing the government, Hutchins in September of 1945 explained that atomic energy would "usher in a new era of peace and plenty," and numerous politicians, academics, news writers, and scientists echoed his sentiments.

Conceptualizations of atomically powered planes, automobiles, ocean liners, and air conditioning units, among others common objects were legion after Hiroshima, beginning with John J. O’ Neill's Almighty Atom: The Real Story of Atomic Energy, appearing days after the bombing. ${ }^{133}$ Radioactive isotopes themselves were singled out often as the answer to numerous peacetime technological problems. Physicist Alvin Weinberg argued isotopes would someday fulfill humankind's fuel and food requirements for "as long as the sun continues to emit light." Weinberg's essay in the February 1946 issue of the New Republic was one of a string of articles that boasted a utopian future realized largely by applications of isotopes to the fields of medicine, agriculture, and energy production. ${ }^{134}$

Though Libby's work with radioactive isotopes at the University of Chicago was related to a federal and institutional interest in isotope technology, it was also a continuation of Libby's prewar work researching the properties of natural isotopes. ${ }^{135}$ Invariably, basic

\footnotetext{
${ }^{131}$ Leopold, 32.

${ }^{132}$ Leopold, 32. Marlowe, Year One, 10.

133 Boyer, 111.

${ }^{134}$ Boyer, 119.
} 
science regarding natural isotopes had halted during the war, and Libby's postwar carbon-14 discoveries are simultaneously a return to basic science questions but also an endeavor associated with the rapidly developing applications for isotope technologies. Many isotopes had been detected in the 1930s, and carbon-14, though postulated earlier, was not detected and measured until just before the war, in 1940. It was then that Martin Kamen and Samuel Ruben detected carbon-14 in Earnest Lawrence's UCLA Berkeley labs. ${ }^{136}$ Libby had personal connections with the 1940 discoverers of carbon-14: Samuel Ruben had been one of Libby's prewar students, and shared with Lawrence, Kamen, and Libby the interest in discovery of isotopes as much to find "any long-lived activity in that part of the radioactive table," as to facilitate practical applications. ${ }^{137}$

Libby's postwar interest in carbon-14, to a certain extant, signaled his shift back to theoretical science, done in a university setting during a period in which basic science was believed imperative for the development of applicable peacetime technologies. Vannevar Bush and philosopher Michael Polanyi, among others, had called for basic or "pure science" to be resumed in the interest of national science growth and stability. ${ }^{138}$ In the case of Bush's statements, historian Nathan Reingold convincingly argues that they were motivated, at the cessation of hostilities, by "Bush's sense of the proper differing roles of industry, government, universities, and the like." ${ }^{\prime 39}$ Bush's position therefore related to a conservative

${ }^{135}$ The dichotomy of "basic" and "applied" science is at one level based on an impossible and indefensible delineation. Yet the categories — when applied to Libby's professional endeavors-help illustrate the multitudinous avenues of inquiry that informed Libby's development of carbon dating.

${ }^{136}$ Kauffman, "Walter D. Kamen,” 305. Also Arnold, 3.

${ }^{137}$ Kauffman, "Walter D. Kamen,” 305.

${ }^{138}$ Vannevar Bush, "Science, the Endless Frontier," and Polanyi, The Logic of Liberty, 3-7.

${ }^{139}$ Nathan Reingold, Science, American Style (New Brunswick: Rutgers University Press, 1991), 305. 
belief "that regular government agencies were inherently flawed." ${ }^{140}$ His position serves to illustrate the manner in which even research in "basic" science remained susceptible to discussion of political motivation and relevance in the immediate postwar period.

\section{Libby's Attempt at Apolitical Science}

Whereas historians have written extensively about politically active atomic scientists in the late 1940s and early 1950s, just as interesting was Libby's personal reticence when it came to political actions or statements until a later period in his career, long after his development of carbon-14 dating. ${ }^{141}$

The application of atomic particle science to bomb technology in the late stages of the war, and the subsequent use of atomic weapons at Hiroshima and Nagasaki, had greatly affected even scientists who had worked on the bombs themselves. Utopian hopes for a future society run on atomic energy coincided with fears of atomic destruction, and the two visions of the atom — as destructor and utopian product—-fueled political and social debate. Scientists were often at the epicenter of such debates, many utilizing their recently minted political currency and proximity to bureaucratic power to make public statements regarding the use and dangers of atomic energy. A loose-knit group of scientists Paul Boyer characterizes as the "Scientist's Movement" worked to safeguard the world from nuclear destruction, and promoted international control of nuclear technology as the best possible

\footnotetext{
${ }^{140}$ Reingold, 304. Bush's statement here seems echoed in some of Johnson's own statements concerning the lack of efficiency of the NRC. Though, illustrating diversity of opinions on the restructuring of the sciences, Libby's statements do not align directly with those of Johnson or of Bush, and his own career trajectory often placed him in the service of government agencies.

${ }^{141}$ See, in particular, Jessica Wang, American Science in an Age of Anxiety, and Paul Boyer, By the Bomb's Early Light.
} 
safeguard. ${ }^{142}$ Albert Einstein, Leo Szilard, Harold Urey, and others each promoted a world government despite the United State's postwar monopoly in regard to nuclear weapons. As Boyer notes, the atomic scientists at the University of Chicago were especially politically active, and made up a large contingency of the scientist's movement. ${ }^{143}$

Though Libby's colleague, mentor, and friend Harold Urey was amongst those who made political statements, Libby was not. Libby, while pointing to the primacy of basic science research (and therefore the potentiality for apolitical work), explained that, during his time at the University of Chicago, "the job was to do science in the broadest sense and also to teach students." 144 Libby found himself a little further from the epicenter of politically charged debate by the fact that, though he had worked on the Manhattan Project, he had been a chemist and not a physicist. Still, his lack of interest in making recorded political statements after the war set him apart from the majority of his colleagues at the University of Chicago.

Libby's silence was motivated perhaps by a disinterest or ambivalence in regard to political questions, but also a level of disagreement with those vocal members of the scientist's movement. Notably, when Libby took a political stance years later, it was to stress the need for arms and research in nuclear technologies in response to the threat of Soviet communism. Libby wrote the preface to Earl Voss's 1963 book Nuclear Ambush: The Test Ban Trap, which argued for the continued testing and development of nuclear weapons. ${ }^{145}$

\footnotetext{
${ }^{142}$ Boyer, 49-64.

${ }^{143}$ Boyer, 49-51.

${ }^{144}$ Libby, “Atomic Nucleus, 528.

${ }^{145}$ Earl H. Voss, Nuclear Ambush, The Test Ban Trap (Washington, D.C.: Regnery Publishing, 1963). Regnery Publishing, based in Washington, D.C., specializes in politically conservative titles and
} topics. 
The fact that Libby did not call for a world government, or for the sharing of American nuclear technologies, and failed to voice other political opinions that came under heavy fire by anti-communist voices (as they gained political currency in the early 1950s) helped Libby avoid security scrutiny and land a number of appointments: "Chief U.S. Spokesman for the Atoms for Peace Initiative" at the 1955 international convention, member of AEC 1954-1959 and director of Project Sunshine (radiation effects testing), Director of the Douglas Aircraft Company (1963), and numerous other advisory placements and awards. ${ }^{146}$

Yet, Libby's sense that his work should focus upon educating students and basic science while at the University of Chicago did not protect him from institutional pressures to create applications for technologies. Hutchins's interest in applied isotope technologies was clear, and was manifest in the "proselytized" message of department leaders Urey and Harrison Brown. They both promoted the production of "more imaginative application for chemical principles," particularly applications situated between "two established disciplines." 147 They were indeed the two who convinced Libby to explain his process to anthropologists connected with the university in a series of inter-departmental meetings starting in May of 1947. Libby's emphasis on basic science, which had the advantage of presenting an apolitical front, melted away once archaeologists were introduced to his untested dating method and realized its potential. Perhaps it was concern about the political difficulties surrounding applied science that motivated Libby to keep the dating method a secret, telling only Urey before December of 1946 (and then only a few colleagues).

Libby's preferences for basic science, and his methodology regarding collaboration, were made inherently political in a post-war climate dominated by the conscious

\footnotetext{
146 “Science: The Philosopher's Stone.” Time, August 15, 1955,

${ }^{147}$ Marlowe, "Year One," 13.
} 
restructuring of administrations. The manner in which science was to be structured became intimately tide to a Cold War politics that emphasized the structural and bureaucratic differences between American and Soviet society. James Burnham's popular book The Managerial Revolution, for example, expressed concern that a growing bureaucratic and administrative class in America would develop oligarchic power. ${ }^{148}$ The debate surrounding the structure of postwar science, led by Vannevar Bush, Alvin Weinberg and others, imparted upon the general climate of research both great difficulty and opportunity. Johnson, for example, saw opportunity for the development of professional organizations in the postwar restructuring of the sciences. He would work for government funding of projects (while at the NRC) yet showed concern the affect of growing government bureaucracy on the sciences. Libby, in turn, struggled to find a niche for his research that would be reminiscent of his role in prewar academia and championed the role of basic science, yet would also accept a number of posts in government agencies throughout his career. ${ }^{149}$

\section{Development of the Carbon-14 dating method}

Parsing out the moment of genesis_Libby's "light bulb" moment when he began to work on the carbon-14 dating method-is complicated by a number of factors. One is that, as Taylor has pointed out, Libby himself was unclear in regard to his recollections of the beginnings of the project, often stating different dates for the moment that the concept of carbon-14 dating occurred to him. ${ }^{150}$ In 1961, after receiving the Nobel Prize in Chemistry

\footnotetext{
${ }^{148}$ Burnham, The Managerial Revolution. The book was published in 1941.

${ }^{149}$ This is not to characterize their perceptions of postwar restructuring as polar opposite; the politics involved in the debate are far too complex for a simple dichotomy.
} 
for the creation of carbon-14 dating, Libby explained that carbon-14 dating had its "origin in a study of the possible effects that cosmic rays might have on the earth and the earth's atmosphere." 151 However, at another point he explained, “As soon as I read Korff's paper [which found neutrons in the atmosphere] . . . that's carbon dating."152

Another difficulty is presented by Libby's self-imposed secrecy about the project until late 1946, when he let his intentions be known at a Christmas party attended by coworkers, including fellow research associate and assistant professor James Arnold. ${ }^{153}$ Libby explained his secrecy as protective of his reputation; he felt that others would consider the possibility too "crazy" and would not lend support and so he kept his interests hidden, at least until he had obtained more evidence of the process's potential success. ${ }^{154}$ Libby's secrecy thwarts attempts at establishing a timeline that includes the genesis of the theoretical aspects of the project by making corroborative testimony or narratives from colleagues all but impossible. Although it appears Libby first told Urey of his plans sometime before mid-1946 (Urey apparently also kept these plans a secret), he had not told even James Arnold at that point; Arnold explained that he had not even heard about Libby's concept of measuring the decay of carbon-14 to date organic materials until the Christmas party at Libby's residence in

${ }^{150}$ Taylor, Archaeological Perspective, 147.

${ }^{151}$ Libby "Radiocarbon Dating," Science, 621. Libby similarly recollected in 1958 that "radiocarbon dating had its origin in a curiosity about the possible effects that cosmic radiation might have on the earth." See Libby, "Atomic Nucleus," 525.

${ }^{152}$ Interview with Willard Libby, 1979, on file at the Center for the History of Physics, American Institute of Physics, College Park, Maryland. Quoted in R.E. Taylor, "Preface," in Radiocarbon After Four Decades: An Interdisciplinary Perspective ed. R.E. Taylor, A. Long, and R. S. Kra (New York: SpringerVerlag, 1992), 1.

${ }^{153}$ Arnold, 4-5. It is in fact, apparently only at that time that Arnold realized hat Libby had been considering applications for radiocarbon beyond that of medical tracer use. See also, Marlowe, "W. F. Libby and the Archaeologists, 1946-1948," Radiocarbon 22 (1980), 1005.

${ }^{154}$ Taylor, Archaeological Perspectives, 152. 
December $1946 .^{155}$ Finally, and most importantly, even if one could pinpoint the moment (or even the year!) in which Libby began to work in earnest on the dating method, one must reconcile the continuity of the theoretical and technological premises of the project with Libby's pre-war work and wartime labors. The carbon-14 dating process integrated many of the technological developments and theoretical presuppositions of Libby's early career in a single endeavor. ${ }^{156}$ Libby's assertion that the carbon-14 dating method originated in an interest in the effects of cosmic radiation means perhaps that he began to mull over the possibility of using the isotope (at that time undetected in natural environs) for the dating of organic materials even before the war. Corroborating this reading is the fact that Libby stated that he did consider the chemistry of carbon-14 during the war, at times, when he was not working directly on uranium enrichment. ${ }^{157}$ Further evidence of Libby's early development of an interest in using carbon-14 to date archaeological materials was Libby's claim that he hired James Arnold (1948) because he was a physical chemist who had an amateur background in Egyptian archaeology."

Libby's and Arnold's work on carbon-14 dating in 1947 served to simultaneously establish new understandings of basic science surrounding carbon-14, and to produce the apparatuses necessary for application of the dating principle. Libby and Arnold faced

${ }^{155}$ Arnold, 4. Also Marlowe, "W. F. Libby Among the Archaeologists,” 1005.

${ }^{156}$ All this points to the need to revisit any narrative in which the history of a scientific endeavor posits a specific moment in which "basic" or theoretical science was discontinued and in which applied science began. When this narrative is set aside, it becomes possible to comprehend Libby's disjointed explanations of the project as having stemmed not from faulty memory but from the inadequacy of defining the stages of the project in this manner.

${ }^{157}$ Taylor, Archaeological Perspectives, 151.

${ }^{158}$ Marlow, “W. F. Libby,” 1008, and R. E. Taylor, "the Introduction of Radiocarbon Dating," 91. Arnold's father was an attorney but also a very skilled amateur Egyptologist and American Secretary of the (British) Egypt Exploration Society. Therefore, James Arnold testified to having developed a fairly solid background in Egyptology facilitated by numerous conversations with his father over the years. His father would, of course, play a role in introducing carbon-14 dating to archaeologists (see below). 
difficult technological hurdles on the way to obtaining accurate readings of carbon-14 content in samples; there was no technique available at the time that would be able to measure the low amounts of the isotope present in samples with adequate precision, and therefore no direct evidence of the existence of the isotope in organic matter. Their solution was to concentrate the heavier isotope carbon-14 from samples by using a thermal diffusion column built to concentrate carbon-13 for medical tracer purposes. The mechanism was privately held by the Houdry Process Corporation of Marcus Hook Pennsylvania and was set to work with methane $\left(\mathrm{CH}_{4}\right)$. Libby and Arnold were able to convince professor Aristide Von Grosse of Temple University to process a sample of methane gathered from the Baltimore sewers system at the Houdry plant. ${ }^{159}$ A related goal of research was to see, after separation of the isotopes, if the heavier isotope was indeed radioactive and therefore likely carbon-14. It turned out to be so, and this was the first hard evidence that natural carbon- 14 did exist and actually found its way into organic matter. ${ }^{160}$ The results therefore pointed towards the creation of naturally formed carbon-14, and the work yielded two joint 1947 papers: the first by Libby, Anderson, and Grosse entitled "Radiocarbon from Cosmic Radiation," and the

${ }^{159}$ Libby "Radiocarbon Dating" 1961 (622-623). Biological methane had to be used because petroleum based methane, though also a derivative of organic materials is from organic source that dies so long ago that it is without carbon-14 content. This lack of radiocarbon in the carbon of petroleum products is the reason for the dilution of carbon-14 in the atmosphere since the onset of the industrial revolution (some scientists this effect my is offset by an unknown extant by the amount of carbon-14 added to the atmosphere by nuclear testing). Von Grosse had briefly worked on the Manhattan Project and also been one of scientists in the 1930s with an interest in cosmic rays; he postulated "cosmic radio-elements," in 1934. See Taylor, blue 152-153.

${ }^{160}$ Libby, "Radiocarbon Dating" (1970), 4. The confirmation of carbon-14 in organic matter during the development of carbon-14 dating was another example of "basic" science, explaining conditions, being accomplished during the act of producing science for direct application. 
second by Grosse and Libby entitled "Cosmic Radiocarbon and Natural Radioactivity of Living Matter."161

The use of a thermal diffusion column in the process of dating archaeological samples would be shown to be cost prohibitive; a more sensitive counter would have to be developed. ${ }^{162}$ After further development of Libby's screen wall counter it was made sensitive enough to measure samples prepared chemically (without the thermal diffusion column), yet there was a great difficulty shielding the samples from other sources of radiation. Eight inches of steel around the sample and the counter took care of most sources of radiation in the laboratory but even that could not shield the sample from cosmic rays; to protect from those Libby and Arnold set up a series of Geiger counters around the sample which would turn off the counter for a fraction of a second when they read radiation. This scenario Libby dubbed an "anti-coincidence arrangement." 163

In the early phase of sample testing, Libby simultaneously sought to perfect the testing method and to test the major assumptions regarding the nature of naturally occurring carbon-14. Ernie Anderson, Libby's graduate student assistant, and another alumni of the

${ }^{161}$ Ernie C. Anderson, Willard Libby, Sidney Winehouse, A. V. Grosse, A. F. Reid, and A. D. Kirshenbaum, "radiocarbon from Cosmic Radiation," Science 105 (May 1947), 576. Also, A. V. Grosse and Willard Libby, "Cosmic Radiocarbon and Natural Radioactivity of Living Matter," Science 25 (July 1947), 88-89. The first paper (printed in the May $30^{\text {th }}$ Science) signaled the beginning of archaeologists awareness of the possibilities of radiocarbon dating; even before publication of the paper Urey and Brown alerted Robert Redfield to the possibility of collaboration amongst the department's based upon Libby's emerging work and had a number of interdisciplinary "seminars" scheduled for later in 1947. See Marlowe, Year One, 13. The second paper had also played a large role in alerting archaeologists of the possibilities of radiocarbon dating, although in a much more serendipitous manner-archaeologist Gordon Hewes read the article and sent a number of letters to archaeologists and Houdry process scientists.

${ }^{162}$ Libby also points out it would therefore "cost thousands of dollars to measure the age of a single mummy." Instead, more sensitive measurement techniques would have to be developed that would eliminate the need for isotope concentration. It is also implied that A. V. Grosse, and/or the Houdry Corporation paid for the sample tests. Libby explained that "Dr. Grosse had spent enough money on the Baltimore sewage sample to run many archaeological museums for a month." Libby "Radiocarbon Dating," (1970) 4.

$$
{ }^{163} \text { Libby, "Radiocarbon Dating,” (1970), } 5 .
$$


Manhattan Project, was able to make his Ph.D. dissertation a test of whether or not carbon14 , once created in atmosphere, was spread equally in the carbon wells of the oceans and dry land of the earth. Samples of modern wood were therefore obtained from each continent (as well as "seal meat and oil from Antarctica" where there wasn't sufficient wood) to be tested. All samples, having come from roughly the same age, "gave the same result," thereby clearing the way for testing of more ancient samples from multiple regions worldwide. ${ }^{164}$ This testing of a contemporary assay, along with Libby's and Arnold's testing of older objects, would in the 1950 s contribute greatly to eco-system science, applied to the study of ocean turnover and currents by Hans Suess, among others. ${ }^{165}$

Changes to the counting method, or physical counting apparatus (screen wall counter), continued until 1948, when the "first true counting system from natural carbon-14 had been invented and was taking shape." ${ }^{\prime 66}$ In the summer of 1948 the first archaeological sample was tested.

\section{Libby, Arnold, and the Archaeologists}

The series of interactions between Libby and archaeologists is the focus of Greg Marlowe's work and has been dealt with in detail by him in two papers. Taylor similarly discusses the events of 1947 and 1948, sometimes summarizing Marlowe, and other times

\footnotetext{
${ }^{164}$ Libby, "Radiocarbon Dating," (1970), 5.
}

${ }^{165}$ See Hans E. Suess, "The Early Radiocarbon Years: Personal Reflections," in Radiocarbon After Four Decades: An Interdisciplinary Perspective, ed. R.E. Taylor, A. Long, and R. S. Kra (New York: Springer-Verlag, 1992), 11-16. Essentially, the technique of following isotope "tracers" through ecosystems would be applied to reveal the manner in which currents in the oceans turn over the water, among other ecological systems. Some of this research would be spurred by atomic testing under water and on atolls.

$$
{ }^{166} \text { Arnold, } 6 .
$$


adding details about the dates inevitably more oriented towards the "physics" side of the story. Yet, the general chronology of events must be outlined here as well.

Willard Libby's first interaction with the archaeological community happened in January of 1947, and was precipitated by Arnold's discussion of carbon-14 dating with his father, a discussion that provided the first package of unsolicited dating materials from Ambrose Lansing (described in the thesis introduction). Soon after, in early 1947, Libby lifted the "veil of secrecy" around his intentions to pursue an archaeological dating method. Yet even then it was far from certain that a professional anthropological or archaeological organization would become the authoritative body that would assist Libby in the testing of the process. ${ }^{167}$ Instead, early suitors included the Viking Fund and the University of Chicago Anthropology Department, both of which gained early knowledge of Libby's work through serendipitous connections with Libby's Nobel laureate colleague Harold Urey. ${ }^{168}$ Paul Fejos of the Viking Fund discovered Libby's intentions when physical anthropologist Ralph Von Koenigswald happen to describe to Fejos an awkward conversation he had had with an unknown physicist over lunch at Cold Springs Harbor Laboratory about the age of the "Solo Man" skull. The physicists claimed that the Solo Man skull could have been dated precisely if it were younger, and this led Fejos to investigate and discover that it had been Libby's colleague Harold Urey who had made the claim. Fejos and Koenigswald both traveled to Chicago to speak to Urey and then to Libby. ${ }^{169}$ It was also Urey and fellow chemist Harrison Brown that convinced Libby to give a series of inter-departmental "seminars" about the dating method starting in May 1947, most of which occurred at the University of Chicago's

\footnotetext{
${ }^{167}$ Greg Marlowe, "W. F. Libby and the Archaeologists," 1006.

${ }^{168}$ For a larger discussion of the Viking Fund see Appendix B.

${ }^{169}$ Marlowe, "W. F. Libby and the Archaeologists," 1007.
} 
Quadrangle Club. The seminars were attended by members of the Department of Anthropology (Robert Redfield, Fay-Cooper Cole, Fred Eggan, Sol Tax, and Kenneth Orr), as well as archaeologists connected to the university's collections at the Oriental Institute (Robert Braidwood and John Wilson), and Donald Collier of the Chicago Natural History Museum. ${ }^{170}$

Frederick Johnson discovered Libby’s intentions perhaps as early as mid June (and no later than late July) of that same year, though through a circuitous route. University of North Dakota anthropologist Gordon W. Hewes read Libby and A.V. Grosse's May 30, 1947, article in Science, "Radiocarbon from Cosmic Radiation," and on June 11th sent letters to A. V. Grosse and numerous anthropologists and archaeologists. ${ }^{171}$ One such letter was sent to Douglas Byers, at the Peabody Foundation, who was Frederick Johnson's superior, collaborator, and with whom Johnson shared office space. Hewes wrote Byers, noting,

In this short, multi-layered paper the announcement is made of a method which seems to be the answer to the dreams of most archaeologists: a direct dating method (in years, or at least in centuries). ${ }^{172}$

Hewes better expressed his excitement in the letter to A.V. Grosse and his associates, explaining, "since reading your report in SCIENCE my head has been literally spinning with speculations on the possible impact of this method of dating on archaeological dating."173

Byers decided that the method might be worth pursuing. He wrote Hewes again, and Hewes forwarded the responses from the Houdry Process Corporation generated by his June

${ }^{170}$ Marlow, "Year One," 13.

${ }^{171}$ Hewes to Dr. S Winehouse, Dr. Reid, A. D. Kichenbaum, and A. V. Grosse at Houdry, June 11, 1947. Also, Hewes to Douglas Byers, June 11, 1947, FJP.

${ }^{172}$ Hewes to Byers June 11, 1947, FJP.

${ }^{173}$ Hewes to Dr. S Weinhouse and Dr. Reid, A. D. Kirchenbaum and A. V. Grosse at Houdry June 11, 1947, FJP. 
11th queries to Byers. These, and perhaps the initial letters, were forwarded to Johnson. On October 28th Johnson wrote Dr. Allen Reid at the Houdry Process Corporation explaining, "a letter dated June 23, 1947 which you wrote Dr. Gordon Hewes of the University of North Dakota was forwarded to me some time ago." He began positioning himself to be part of an interdisciplinary collaboration, noting,

should close collaboration between various scientific fields be instituted the inevitable result should be of mutual benefit to everyone concerned and, as a matter of fact, eventually to science as a whole. ${ }^{174}$

The October $28^{\text {th }}$ date of Johnson's letter to Reid may have been prompted as well by Paul Fejos and G.H. Ralph von Koenigswald's description of the dating process (culled from their discussion with Harold Urey) at an October 17 Viking Fund Dinner, which Johnson may have either attended or about which he had been informed. ${ }^{175}$ Generally, awareness of the dating process had been leaked to multiple archaeologists under the auspices of numerous organizations, yet clearly Johnson was well positioned to become a key player in many of the potential archaeological responses to Libby's work.

In December Johnson wrote to Paul Fejos of the Viking Fund (whom he knew from their work together to create funding for the CRAR) to discuss carbon-14 dating. Further positioning himself he noted, "I[t] [sic] seems probable that the archaeological field should be represented by a committee to act in an advisory capacity." He headed off any discussion of the NRC becoming the lead organization in the integration of the dating process stating that he feared that important aspects would get lost in the red tape therein. ${ }^{176}$

${ }^{174}$ Johnson to Dr. Allen F. Reid, Houdry Process Corporation, Oct 28 1947, FJP.

${ }^{175}$ Marlowe, "Year One," 19. The dinners were held once a month in New York, and Johnson certainly attended a few of them, and the one in January of 1947 for certain. 
The relationship between Libby and Fejos of the Viking Fund continued to expand after Fejos's and Von Koeningswald's visit to see him and Urey earlier in the summer. The Viking Fund was a possible source of funding for Libby's testing of the dating process. What Libby and Fejos both needed was further evidence the process could be successfully integrated into archaeological practice.

Libby gave a one-hour long speech about the method at a Viking Fund dinner January 9, 1948, which marked the point where archaeologists (outside of Chicago) were invited to hear about the developing dating method in detail. Although Libby believed that he had given a presentation sufficiently devoid of technical information so as to be intelligible to all, there apparently was widespread confusion after his presentation. Despite Libby's hope that the presentation would create interest in the donation of samples for testing, there were little questions presenting the semblance of general disinterest. ${ }^{177}$

At this point, January 1948, Libby waited to see if archaeologists would be able to drum up support for an organized body to assist him in the testing process.

${ }^{176}$ Dec 22, 1947 Johnson to Fejos, FJP

${ }^{177}$ Marlow, "W. F. Libby among the Archaeologists," 1010. Geologist Richard Flint was one of the few who showed direct interest in providing samples, but his understanding of the situation had not come from the talk alone-Johnson and Flint had been "briefed" on Libby's talk beforehand by Fejos. Flint was briefed, most likely because he was the liaison to the NRC geology section. Flint would also become the lone geologist on the CRC14. The fact that Johnson was “briefed" by Fejos relates Johnson's success at connecting himself with each "key players" involved in the presentation of the dating process. 


\section{CHAPTER 3: THE NEW COMMITTEE}

In 1947, archaeologists opinions about atomic science were mixed, and reflected a lack of understanding of particle physics. Johnson's own recollections of Libby’s January 9, 1948, Viking Fund dinner, in which archaeologists were given an explanation of the carbon14 process, are revealing:

... aside from Jim Arnold and [Aristid von] Grosse, there was no one there who understood the physics and the chemistry. Fejos had briefed Flint and me separately so we were neither shocked nor surprised. Still, I only barely understood the gist of what Libby had to say. I suspect that Flint was not much better informed. ${ }^{178}$

It has been noted by a plethora of other cultural historians that the rubric of "atomic science" was powerfully employed in popular imagination after the Manhattan Project and subsequent bomb trials, and it is no less interesting to examine the confusion and awe that the rubric meant to the minds of those engaged in postwar archaeology. ${ }^{179}$ Archaeologists trained in Johnson's generation spent only a fraction of time and energy in laboratory settings. Stratigraphy, and an interest in chronologies had only replaced ethnological taxonomic classification in the early part of the century. The archaeological laboratory rose to prominence in the twenties along with the movement of "culture history" and the waning of museum sponsored work that favored the recovery of presentable objects over statistical analysis of sites. ${ }^{180}$

\footnotetext{
${ }^{178}$ Marlow, "W. F. Libby among the Archaeologists," 1010.

${ }^{179}$ See Boyer, and Leopold, throughout.

${ }^{180}$ R. Lee Lyman and Michael J. O'Brien, The Rise and Fall of Culture History
} 
Despite these facts, news of Libby's testing of a dating method that utilized isotopes spread quickly through the archaeological community. Months before Libby's Viking dinner presentation, in July of 1947 , archaeologist and SAA president Waldo Wedel sent a letter to Frederick Johnson suggesting that Johnson's powerful SAA committee-the Committee for the Recovery of Archaeological Remains (CRAR)—should spearhead the integration of C14 into the practice of archaeology. ${ }^{181}$ Johnson's response was to push for the development of a separate committee, arguing that while Libby tested his dating process, "the archaeological field should be represented by a committee to act in an advisory capacity." He further suggested that the task of forming a committee be sent to the planning body of the SAA, noting that this is the sort of thing for which the Planning Committee of the Society of America Archaeology was formed"182 (Johnson was also a key member of the SAA Planning Committee). Johnson suggested that the collaborative effort should be governed by a committee of the SAA and thereby be made to promote the consolidation of authority within one of the larger professional archaeological organizations.

Though there had been many early "suitors" in archaeology interested in Libby's dating process (the University of Chicago Anthropology Department, The Viking Fund) it was not an academic department or even a committee of the SAA that designed the committee with which Libby would work. Instead it was the older anthropological organization, the AAA, which put together a committee on January $28,1948 .{ }^{183}$ Frederick

\footnotetext{
${ }^{181}$ Marlowe, "Year One," 17. See also Fred Wendorf and Raymond H. Thompson, “The Committee for the Recovery of Archaeological Remains." Like Byers, Wendel found out about radiocarbon dating from Hewes in June/July; Byers had run into Hewes at an anthropology conference in Bismarck North Dakota that summer. As discussed in the end of the last chapter, even before Wendel wrote Johnson, it is most likely that Byers had already informed Johnson about radiocarbon dating.

${ }^{182}$ Frederick Johnson to Paul Fejos, December 22, 1947, Box 1, folder “A-G Carbon-14 1948-Aug $1950, "$ FJP.
} 
Johnson was appointed to head the committee (notably he was positioned to head a committee either for the SAA or the AAA). The choice of Johnson to head the committee was certainly fostered by a number of realities. 1) Johnson had run the CRAR, showing his adept abilities dealing with interdisciplinary collaboration and large bureaucracies like that of the Federal Government. 2) Johnson had a detailed and friendly relationship with the Viking Foundation, which had already contacted Libby and could provide a source of funding for the committee and Libby's work. 3) Johnson clearly had Americanist archaeology, and professional organizations that supported Americanist endeavors close at mind, and would presumably continue to do so. 4) Johnson had generally promoted collaborative or interdisciplinary endeavors as governable by professional organizations.

The fact that the AAA and not the SAA (which had earlier committee ambitions) ended up designing and appointing the committee is perhaps indicative of the larger membership and resources of the AAA, and the fact that the AAA served the larger anthropological community. The membership of the AAA was more diverse than the SAA; the SAA existed to assist archaeologists whose interests were sites in the Americas, whereas the AAA served American anthropologists, ethnologists and archaeologists whose work was conducted worldwide. Furthermore, membership extended to professional and amateur practitioners in multiple fields (the AAA had maintained membership to amateurs, despite growing emphasis on professionals in archaeology).

Libby signed off on the committee, accepting it as the organizational authority for archaeological collaboration for the testing phase of his work. Along with Johnson, two other AAA members were appointed initially to the committee. These were Froelich Rainey, director of the University Museum at the University of Pennsylvania, and Donald Collier,

${ }^{183}$ Marlowe, "Year One,” 26. 
curator of South American archaeology and ethnology at the Chicago Natural History Museum. It is interesting to note that Collier was the choice for the committee, and the only member of the Quadrangle Club "seminars" not affiliated directly with the University of Chicago's anthropology department or Oriental Institute. ${ }^{184}$ Soon after Flint was added to represent geological interests in the dating method. ${ }^{185}$

A focus upon American archaeological sites and artifacts, which was indeed promoted by the committee, would not have been the case under the authority of the other early "suitors." The Viking Fund had originated in Europe (as did Paul Fejos, who was Hungarian) and had an interest in international archaeological endeavors, particularly those in Mexico under the auspices of the organizations consistent collaboration with archaeologist Helmut de Terra. The University of Chicago contained perhaps America's most extensive collection of Middle Eastern artifacts in the University's Oriental Institute, and employed one of the world's authorities on Middle Eastern societies in the person of Robert Braidwood (who provided a number of the 1947 samples for Libby from his Middle East archaeological work before development of the AAA committee). Libby in 1947, when considering archaeology, seems to have thought principally of the Middle East and, more precisely, of Egypt. Libby hired chemist Jim Arnold in part because Arnold had some experience with Egyptology; Arnold's father's amateur archaeological pursuits meant that Arnold had "learned the Egyptian dynasties and kinglists at an early age." "186 (As discussed earlier, the

\footnotetext{
${ }^{184}$ Richard B. Woodbury, “Obituary: John Otis Brew,” American Antiquity 55 (1990): 452-459. Collier began teaching at the University of Chicago in 1950.

${ }^{185}$ Flint had been Libby's suggestion, perhaps because of Flint's vocal interest at the January 1948 Viking Dinner.

${ }^{186}$ Anderson's note about publication no. 46 “Age Determination by Radiocarbon Content: World Wide Assay of Natural Radiocarbon" in The Publications of Willard Frank Libby, Vol. 1: Radiocarbon and Tritium.
} 
first sample tested came through Arnold's father, A. S. Arnold, to Libby from Ambrose Lansing of the Department of Egypt Art, the Metropolitan Museum of Art, New York.) ${ }^{187}$ After Arnold's arrival an amusing story exists that Arnold brought with him an Egyptian medallion, the "Seeing Eye of Ra", which Libby had mounted on the wall in the laboratory to "keep an eye on the scientists." "188 Libby’s own juxtaposition of Egyptology with archaeological pursuits was perhaps fueled by the great popular awareness of Egyptology after the celebrated discoveries of the first half of the century, most notably the unearthing of the tomb of Tutankhamen in the period immediately before the war.

Yet, despite the diverse basis of the AAA's membership and Libby's early utilization of artifacts from ancient Egyptian assays, the CRC14 was made up entirely of archaeologists who studied American sites; Johnson and Rainey studied North American Indian populations, and Collier studied North and South American Indians. In this way, the AAA appointed committee initially served American archaeological interests far more than those of anthropologists whose work lay abroad.

\section{The First Year: February 1948-May 1949.}

Soon after the AAA established The CRC14 the three initial members-Frederick Johnson, Froelich Rainey and Donald Collier-were sent identical letters from AAA president Harry Shapiro, describing their assignment. ${ }^{189}$ Johnson wrote his first letter to

${ }^{187}$ Marlowe, "Year One," 12.

${ }^{188}$ Introduction to Libby 46 “Age Determination by Radiocarbon Content: World-Wide Assay of Natural Radiocarbon” Willard F. Libby Collected Papers, Vol. 1 Tritium and Radiocarbon, Geo Science Analytical, Inc., 1981.

${ }^{189}$ Marlowe, "Year One," 26 (endnote 18). 
Willard Libby days later on February 9 and explained the directive of the project, quoting at

length the language of the charter:

Our only specific directive is 'That this committee be empowered to offer all immediate assistance possible to Dr. Libby by providing him with dateable archaeological material which he can use in checking his techniques.' It is also suggested that we attempt to establish contact and affiliations with all interested societies and that, as a permanent committee, we investigate the possibility of establishing a very close connection with the National Research Council. ${ }^{190}$

The singular directive passed down from the American Anthropological Association reflected Libby's own request to the archeological community for assistance procuring samples, a request he had made at special dinners hosted by the Viking Fund on October 17, 1947 and January 9, 1949. ${ }^{191}$ As Libby had envisioned the testing, the most appropriate initial testing material would be samples of a known age of more than 4000 years, which could be used to calibrate the apparatus. ${ }^{192}$

As of February 20, Johnson had not heard back from Libby. Considering the fact the committee had been formed to deal with Libby's request for samples Johnson was concerned by the silence, and related this concern to fellow archaeologist and head of the Peabody Museum, Jo Brew. ${ }^{193}$ Had Johnson known Libby better at that point in their correspondence he would have recognized that this silence was not out of character; Libby often worked on

\footnotetext{
${ }^{190}$ Frederick Johnson to Willard Libby, February 9, 1948, box 1, folder "Carbon-14 Arnold and Libby 1948 to Aug 1950," FJP. Owing perhaps to Johnson's opinion of the NRC, with the exception of the appointment of Flint (and his NRC connections) to the committee, there is no evidence that Johnson tried to create a "very close connection" with the NRC.

${ }^{191}$ The Viking Fund (currently known as the Wenner-Gren Fund) was, and is, a foundation for anthropological research. See Ruth Benedict, "The Viking Fund," American Anthropologist 49 (1947): 527-530, and Appendix B of this thesis. The fund and its director Paul Fejos would continue to support the project through the testing phase. Johnson was already familiar with the fund and Fejos, and had requested and received funding for the CRAR prior to the C14 Committee. See Also Appendix B.

${ }^{192}$ Arnold, 7. Also, Frederick Johnson, et al., "Radiocarbon Dating," 2.

${ }^{193}$ Frederick Johnson to Jo Brew, February 20, 1948, box 1, folder "Carbon-14 Arnold and Libby 1948 to Aug 1950," FJP.
} 
many things at once, juggling different projects, often letting one project sit unattended for a long duration as he worked on other business, only to suddenly re-apply his energies to an unattended project with great fervor. ${ }^{194}$ Compounding Johnson's worry in regard to Libby's silence were reports from Brew that, while on his stay in Chicago, he had come to know that Libby was continuing to request samples through Frederick Eggan of the University of Chicago's Anthropology Department. ${ }^{195}$ Johnson voiced his dissatisfaction to Brew (with whom he served on the CRAR and had a cordial professional and personal relationship, attested to by the familiarity apparent in his hand written letters) by complaining that Libby himself had requested the committee though he, ironically, did not seem particularly interested in using it. ${ }^{196}$

The same day Johnson sent off a (typed) letter to Eggan, clearly hoping to head off a power-struggle over the dating process. Addressing the suggestion that the committee had been tactlessly created in spite of the University of Chicago Anthropology Department's implied jurisdiction, Johnson rattled off that Libby had requested the committee, the executive board of the AAA had chosen the members, and that "no member asked for the job as far as I know." He softened his comments by explaining that he hoped for "open discussion" if there was "indeed discord." 197 Eggan quickly wrote back (his letter is

\footnotetext{
${ }^{194}$ Frederick Johnson to Fred Eggan, February 20, 1948, box 1, folder "Carbon-14 Arnold and Libby 1948 to Aug 1950," FJP. James Arnold's discussion of Libby's working methods in James Arnold, "The Early Years With Libby at Chicago: A Retrospective," is most revealing. Also Hans S. Suess, "The Early Radiocarbon Years: Personal Reflections." Suess writes, "I approached him bravely and asked him if I could see him in his office and talk about his C14 dating method. ...' Next week, Tuesday, Three in the afternoon, he said, and without waiting for an answer, walked away.",

${ }^{195}$ Johnson and colleague John O Brew (Jo Brew) served together on the CRAR, and Brew, as director of the Peabody, spent much of the year in close proximity to Johnson. In 1948, Brew was also head of the SAA.

${ }^{196}$ Frederick Johnson to Jo Brew, Box 1folder “A-G Carbon-14 1948-Aug 1950,” FJP.
} 
addressed only three days after Johnson's) and assured Johnson, “There are some angles that annoy me somewhat but they have absolutely nothing to do with your committee."198

The "discord," as noted above, had roots in the distinct social and political concerns of divergent archaeological specializations. Nearly all of the early samples given to Libby through the University of Chicago and through an earlier connection to the Metropolitan Museum of New York had come from "Old World" archaeologists, particularly by those who specialized in Egyptology. Egyptian artifacts made particularly good testing materials because Libby had asked for objects with established chronologies, and the only chronology of any great length backed by written sources by 1947/1948 was the Egyptian chronology. ${ }^{199}$ At that time, there were no cultural relics in the Americas known to provide a chronology nearing that of the Egyptian in detail or length into the past. ${ }^{200}$

Yet Johnson, Collier and Rainey were all Americanist archaeologists. Rainey and Johnson had particular interest in the theories of migration of Indians to the Americas across the Bering Strait, and therefore detailed interests in long period chronologies in the Americas. Collier's position as the Curator of South and Central American Archaeology at the Chicago Field Museum left him with similar interests, and though Collier's specialties were somewhat international it is important to note that Collier was chosen to be on the committee at least in

\footnotetext{
${ }^{197}$ Frederick Johnson to Fred Eggan, February 20, 1948, Box 1folder “A-G Carbon-14 1948-Aug 1950," FJP.

${ }^{198}$ Fred Eggan to Frederick Johnson, February 23, 1948, Box 1folder "A-G Carbon-14 1948-Aug $1950, "$ FJP.

${ }^{199}$ William C. Hayes, Chronology: Egypt-To the End of the Twentieth Dynasty (Cambridge: Cambridge University Pres, 1964), 21-23. Also Mathew Hedman, The Age of Everything (Chicago: The University of Chicago Press, 2007), 27-48. The Egyptian chronology was ascertained by anchoring written records (king lists) with astronomical occurrences describe during the reigns of various pharaohs. Because the correlations generally had to do with the star Sirius, or Sothis, the pattern was known as the Sothic Cycle. Work on this method of dating began in the early twentieth century.

${ }^{200}$ Hedman, 15. Mayan calendar work did not begin to show connections to Mayan texts until the work of Tatiana Proskouriakoff in the 1960s.
} 
part because Libby had requested a member from the Chicago area, presumably to make weekly face to face correspondence with a committee member possible. ${ }^{201}$ A direct result of the AAA committee choice of Frederick Johnson as Chair and Froelich Rainey and Donald Collier as members was Americanist committee leanings and the preference for testing artifacts to come from American sites, particularly North American sites. Of the 242 assay dates published in Libby's book Radiocarbon (1952), 133 were from U.S. sites. If the North American sites found in Mexico and Canada are included in the tally the number is 150 of first $242 .{ }^{202}$ Of the 40 that came from European or Middle Eastern excavations, many had become part of the sample assays early in the testing process, before the active period of the CRC14. This phenomenon is explained, in part, by Johnson's greater personal connections with Americanist archaeologists, and therefore the tendency for him to be aware of their dig sites and recovered materials, as well as the greater likelihood that he would correspond regularly with these individuals. Yet, the realization that many European and Middle Eastern objects had relative or even absolute dates that were corroborated by textual sources or by well established pottery chronologies, and thereby were better candidates for verification of the carbon dating process, makes the committee's choice to use a majority of samples from North American sites all the more curious, and points to an Americanist agenda.

Despite Johnson's claim that the Executive Board of the AAA had chosen the committee membership, members could not have better reflected Johnson's preferences.

${ }^{201}$ Marlowe, "Year One," 26.

${ }^{202}$ Drawn from the first official list of radiocarbon dates for general use, printed in Willard Libby, Radiocarbon Dating (Chicago: University of Chicago Press, 1952), 70-96. Also printed in Frederick Johnson, et al. "Radiocarbon Dating: A Report on the Program to Aid in the Development of the Method of Dating," Memoirs of the Society for American Archaeology No. 8, (1951). The early mimeographed list (1950) that Taylor explains was shorter (148) but had similar results, with $58 \%$ of samples being of North American origin. Taylor "The Introduction of Radiocarbon Dating," 94. 
Rainey's directorship of the Museum at the University of Pennsylvania, (Johnson's undergraduate alma mater), only augmented Johnson's long-standing relationship with that collection. And Collier was from Chicago (as Libby requested) but was not from the University of Chicago Anthropology Department or the Oriental Institute, which had presented the Committee with its earliest rival for autonomous control of archaeological aspects of the dating method.

It begs the question of why the AAA would appoint a committee so narrowly focused on Americanist archaeology. It may simply be that the Executive Committee surmised that Johnson and his agenda represented the most promising avenue to successful testing and integration of the process, and therefore his interests in producing a committee held sway. Under the leadership of individuals like Franz Boas and Frederick Ward Putnam, the organization's beginnings were foremost in American folklore and anthropology, and the influence of the founding concerns remained strong in the organization. There may have also been some concern by administrative members of the AAA over a conceived sensitive nature to Libby's scientific work, involving the understanding (or misunderstanding) that the carbon-14 process had been devised based upon wartime atomic work. ${ }^{203}$

The choice to promote Americanist archaeology may be related to the mid-century emergence of American archaeology as a well-funded discipline, propelled by recent innovations in theory and by merging nationalist goals. The committee's bias also reflected longer trends affecting Middle Eastern and European archaeology. Interest in America in Middle Eastern archaeology had been waning since the turn of the twentieth century, when

\footnotetext{
203 AAA archival materials, unfortunately beyond the scope of this thesis, may perhaps provide answers to these questions.
} 
the search for physical corroboration of Biblical narratives fell off considerably. ${ }^{204}$ In the immediate postwar period the influx of federal money into archaeology done in the United States reflected a nationalization of science pursuits, related to a war formed symbiosis of science and federal policy. Johnson's own role in the creation of archaeological projects related to federal projects and federal dollars while working for the CRAR before and after the war. ${ }^{205}$

The end effect was that archaeologists whose work related to the Middle East or Europe were left without a representative on the CRC14. Johnson had this discord in mind when writing to Eggan:

There has been considerable criticism of the committee. The basis for this seems to be that there are no Old World archaeologists on the committee. They seem to feel that as long as there are not it will be impossible for the committee to obtain, for Libby, samples from across the water. Well, maybe so. ${ }^{206}$

Johnson hoped that "Old World" archaeologists would collaborate, though in the same letter he clearly expressed the frank persistence for which he was well known. The open invitation for submissions from European and Middle Eastern chronologies stood, though as will be shown when the committee chose official collaborators in 1949, all but two chosen were archaeologists working in the Americas and consequently the carbon-14 dating of Europe and the Middle East lagged during the testing phase.

\footnotetext{
${ }^{204}$ Although much of the archaeology of the Middle East that was interested in corroborating biblical narratives was done by European organizations like London's Biblical Archaeological Society, there were American counterparts. See Kuklick, Puritans in Babylon, among others. Laura Robson discusses British Protestant archaeological interests in the holy land in Laura C. Robeson, "Archaeology and Mission: The British Presence in Nineteenth Century Jerusalem," Jerusalem Quarterly 40 (2009).

${ }^{205}$ Fred Wendorf and Raymond H. Thompson, "The Committee for the Recovery of Archaeological Remains: Three Decades of Service to the Archaeological Profession," and also Paul Faggette, Digging for Dollars: American Archaeology and the New Deal (Albuquerque: University of New Mexico, 1996).

${ }^{206}$ Frederick Johnson to Fred Eggan, February 20, 1948, Box 1folder "A-G Carbon-14 1948-Aug 1950," FJP.
} 
The situation was serious enough that Johnson requested from the AAA the power to appoint to the committee another archaeologist, and AAA President Shapiro answered, "by all means go ahead and add to the committee any classical archaeologist that could be representative of the field as a whole." Shapiro further offered, "I suspect [Robert] Braidwood might be an excellent choice."207 The fact the Braidwood was a University of Chicago archaeologist connected to the Oriental Institute meant perhaps that Shapiro was either unaware of Johnson's struggle with the department, or else well aware of them and suggested an individual that could bring the Chicago archaeologists into the program in the interest of peaceful relations. In an amusing turn, which also further illustrated the limited conceptualization of atomic science amongst archaeologists, Shapiro added in his letter to Johnson, "maybe you aught to drop a little nuclear fission onto some of these commentators who are yapping at your heels."208 Despite the permission, Johnson, in clear example of his careful protection of the autonomous status of the committee, did not add a classical archaeologist.

Eggan's assurances that there was no competition underway from the anthropology department at the University of Chicago did not satisfy Johnson and he met with Libby's assistant, James Arnold, along with Jo Brew (who was still in Chicago) on February 26. ${ }^{209}$ Why Libby was unable to attend is not clear, nor is it clear if Johnson had yet made direct contact with the physical chemist. Certainly, in that period Libby had other contracts and projects, and would travel often—particularly to California where there were important

\footnotetext{
${ }^{207}$ Harry Shapiro to Frederick Johnson, February 25, 1948, Box 1folder "Folder Q-T Carbon-14 1948Aug 1950," FJP.

${ }^{208}$ Harry Shapiro to Frederick Johnson, February 25, 1948, Box 1folder "Folder Q-T Carbon-14 1948Aug 1950," FJP.

${ }^{209}$ Frederick Johnson to John O. Brew, February 27, 1948, Box 1folder "A-G Carbon-14 1948-Aug 1950," FJP.
} 
scientific facilities at UCLA and Berkeley with which Libby would continue to have specific ties.

Johnson continued through the spring to field queries from parties interested in "donating" samples, some from European and Middle Eastern museum collections, but as of April he was redirecting these queries to Rainey. ${ }^{210}$ Johnson traveled to a remote field site in the Yukon on May 12 in accordance with what Marlow has called a "peculiarity of archaeology," namely that during the finer weather of the summer much of the committee and administrative work in professional archaeology is often suspended as archaeologists take to the field. ${ }^{211}$ Johnson's correspondence over the summer in regard to the committee and its goals was indeed sparse, and seems to have only been sent to Rainey, the administrator of committee business in Johnson's absence. With the details of sample collection in the hands of Rainey and Collier, Johnson continued to imagine the manner in which carbon-14 dating would be integrated into the practice of archaeology once Libby's testing had been completed. He sent a note to Rainey from the field describing his thoughts for a dating facility run by a professional archaeological organization:

Sooner or later if dating is to be done, a plant will have to be built. It seems best to locate the thing in the Chicago area where Libby can keep an eye on it. Ownership will be a problem. Fejos wants the SAA to do it. There is considerable objection to a combined SAA-Geol. or NRC, or AAA sponsorship. But in any case it must not be a private organization like a museum or university. ${ }^{212}$

\footnotetext{
${ }^{210}$ Frederick Johnson to Dr. Dow Dunham, April 30, 1948, Box 1folder “A-G Carbon-14 1948-Aug 1950," “The Frederick Johnson Papers 1948-1968." Dow Dunam was curator of Egyptian Art, the Museum of Fine Arts, Boston. He had offered samples.

${ }^{211}$ Marlow, "Radiocarbon Dating," 14. Johnson's work in the Yukon was another interdisciplinary endeavor with botanist Haup Raup. It was a joint Harvard-Andover dig along the Alcan Highway. See MacNeisch, "Frederick Johnson: Obituary," 270.

${ }^{212}$ Frederick Johnson to Froliech Rainey, May 15, 1948, Box 1folder "Folder Q-T Carbon-14 1948Aug 1950," FJP. The letter was sent from Burwash Landing, Whitehorse, Yukon Territory.
} 
These comments reveal a number of presuppositions. The first is that Johnson envisioned the committee would serve the purpose of integrating the carbon dating technique into archaeological practice, going beyond the singular directive the committee had received from the AAA. Second, Johnson assumed the eventual successful trial of the process in which tests would prove the technique accurate. Finally, Johnson was most likely thinking of the University of Chicago in particular when he noted the possibility of a university being in direct "ownership" of the dating process. There was indeed ample reason to suspect that the university could claim some level of "ownership." The University of Chicago had paid Libby's salary during development (though not Arnold's salary, which had been paid by the Viking Fund) and was the main funding source for Libby's initial work on the project- the "basic" science that would provide the basis for the dating process. ${ }^{213}$ Yet when Libby had begun applied work on the dating method apparatus, funding came almost entirely from the Viking Fund (the small exception being an Air Force contract in 1949 for development of "low level counting techniques" which "were put to immediate use in the radiocarbon dating research"). ${ }^{214}$ Even with these exceptions, proprietary claims could perhaps have come even from the University of Chicago's anthropology department, which had supplied many early samples.

But perhaps most strikingly, Johnson in the above statement reveals his philosophy in regard to the structuring of archaeological sciences around professional organizations. His voiced concerns about private ownership of the dating "plant" are in line with Johnson's long

\footnotetext{
${ }^{213}$ Libby had worked in 1946-1947 on projects regarding radioactive isotopes including work the nature of carbon-14 and work developing techniques to detect and measure low levels of radioactive isotopes. By Libby's own account, he had already considered the possibility that naturally occurring carbon-14 could be used to date objects but he did not reveal it to anyone (including Arnold) until a party at Libby's home in the second half of 1946. See Arnold, 4.

${ }^{214}$ Libby, Radiocarbon Dating, v.
} 
career of volunteer service with professional organizations, and disinterest in furthering the authority of academic institutions or federal agencies. It was in professional organizations like the SAA and AAA that Johnson was himself able to exercise the most influence over archaeological practice; his promotion of those organizations also had roots in his contention that they best served the science of anthropology. In his article "Anthropological Professional Organizations," Johnson lauded the fundraising, organizational, and promotional acts of anthropological organizations. He pointed to national anthropological organizations as organizations of extreme importance, and explains that the meetings of professional organizations allows for members to "gather freely to exchange information," pointedly representing professional organizations as protective basic science. ${ }^{215}$ Perhaps his use of the term "private" in his letter reveals his sense that professional organizations were pluralistic centers for the science in contrast to a private set of interests.

Johnson returned from fieldwork in the Yukon to Andover in October 1948. Libby sent a mid-October letter in which he assured Johnson that Rainey and Collier had sent him samples over the summer and that initial results were encouraging. These samples included a number of modern-day organic samples, or "terrestrial biosphere samples," from differing geometric latitudes meant to corroborate one of the basic assumptions necessary for carbon14 dating: that carbon-14, produced in the atmosphere, was uniformly precipitated upon the surface of the earth. If that assumption had proven false, the method's utility would have been fundamentally threatened. Samples included white spruce Johnson himself had collected in the Yukon, numerous other wood samples from Europe and the Americas presented by Collier, and samples from other individuals Libby queried independently. ${ }^{216}$

\footnotetext{
${ }^{215}$ Frederick Johnson, “Anthropological Professional Associations,” 436-37.
} 
This testing of contemporary samples seems to have occurred intermittently throughout the summer and through the rest of the year, as Libby continued also to test a backlog of samples that had not been provided by the committee but had come largely from the Oriental Institute and Metropolitan Museum. Early tests of ancient artifacts did include a Cyprus beam (test no. 12) from the Egyptian tomb of Sneferu submitted by Froelich Rainey (presumably from the University of Pennsylvania museum collections), and charcoal and charred wood (test no. 101) from a 1500-year-old buried layer in the Yukon submitted by Johnson. $^{217}$

Johnson took the success of the summer samples to mean that the committee should readdress the singular directive and expressed this point to Libby on October 26:

In view of this, it seems to me that we should reorganize and expand this committee. I would appreciate receiving from you information which will aid us in doing this. I remember discussing the question of constructing a plant to do the work and financial problems connected with this. If you are planning to go ahead in one way or another, it is essential that this Committee [sic] be reorganized so that it can be useful to you. ${ }^{218}$

Johnson continued through the end of that first year to develop the concept of a plant run by an archaeological professional organization and administered through the work of an expanded committee. His November 9 letter to Libby explained that he had talked to Dr. Fejos about the "problems" getting the plant done and asked Libby for more details about the limits of the process as well as a sense of "the number of specimens that can be handled [by the plant] per year." These numbers would presumably give Johnson a sense of the running costs and therefore the feasibility of the project for a professional organization. He also made

${ }^{216}$ Willard Libby, "Radiocarbon Dating," Philosophical Transactions of the Royal Society of London. Series A, Mathematical and Physical Sciences 269, No 1193, (1970): 6.

${ }^{217}$ Willard Libby, Radiocarbon Dating, 70, 89.

${ }^{218}$ Frederick Johnson to Willard Libby, October 26, 1948, box 1, folder "Carbon-14 Arnold and Libby 1948 to Aug 1950," FJP. 
clear that he wished Libby keep these numbers confidential, stating, "I would appreciate such information which I would treat as confidential if you so desire so that Rainey and I can begin to develop the means for handling the whole project."219

Johnson hoped to ascertain whether demand for dated artifacts would warrant the building of the plant. Collier tallied those samples already offered and argued that there were enough for the plant to run for two years and that, "after the first boom, the supply of samples will be governed to a great extent by the cost per date."220 Johnson's and the committee's fear that there would not be enough samples to warrant the building of a facility reflected the practical concern that the cost per sample was an unknown (and would surely effect demand) but also seems to have reflected a far too conservative estimate of practical interest in the dating method amongst archaeologists and geologists.

Johnson's interest in the details involved in building a facility was perhaps the impetus behind a December 6 trip to the labs, in which he, Collier, and Rainey gained some first hand insight into the manner in which the testing was done. ${ }^{221}$ It was at this time that Libby was installing a thermal diffusion column, and this advancement, and the excitement surrounding the developments may have also been at the heart of the visit. Johnson's understanding was that the new column would lead to further precision of dates. ${ }^{222} \mathrm{He}$ sent a letter to both Rainey and Collier four days after the visit stating his heightened sense of

\footnotetext{
${ }^{219}$ Frederick Johnson to Willard Libby, November 9, 1948, box 1, folder "Carbon-14 Arnold and Libby 1948 to Aug 1950," FJP.

${ }^{220}$ Frederick Johnson to Donald Collier, December 13, box 2, folder "Correspondence with Committee Members" FJP.

${ }^{221}$ Froliech Rainey letter to Paul Fejos, January 27, 1949, box 2, folder "Correspondence with Committee Members," FJP.

${ }^{222}$ Frederick Johnson to Paul Fejos, undated letter-marked "draft", Box 1folder "A-G Carbon-14 1948-Aug 1950," FJP.
} 
Libby's expertise. "One thing that is heartening to me is an impression that Libby is intellectually honest, that this is no fly by night project." 223

Soon after the committee meeting Libby contacted Fejos at the Viking Fund with his financial needs for the running of the testing program for 1949 . They totaled $\$ 20,000$ and included:

\section{$\$ 5,400$ for Arnold's salary}

$\$ 4,600$ for one full time and one part time assistant

$\$ 5,000$ for equipment

$\$ 5,000$ for operating costs. ${ }^{224}$

Libby had received financial support from the Viking Fund during the phase in which he had introduced the untested method to archaeologists (1947), and had been granted the platform in which to reach a large archaeological audience-namely the Viking dinners of October 17, 1948 and January 9, 1949. But the fact that funding for the larger (and more expensive) testing phase of the dating method (including Arnold's salary) would come almost entirely from the foundation, clearly designated that the professional archaeology and anthropology foundations (and not the University of Chicago or a physics funding apparatus, i.e. a federal program, a military branch, etc.) now held the largest financial stake in the process. This fact was not lost on Johnson, who supported Libby's requests for funding from the Viking Fund with further discussions and correspondence with the fund director Fejos. ${ }^{225}$

\footnotetext{
${ }^{223}$ Frederick Johnson to Froliech Rainey and Donald Collier Dec 10, 1948, box 2, folder “Correspondence with Committee Members" FJP. Also Donald Collier to Frederick Johnson, Dec 13, 1948, FJP.

${ }^{224}$ Willard Libby to Paul Fejos, December 13, 1948, box 1, folder “Carbon-14 Arnold and Libby 1948 to Aug 1950," FJP.

${ }^{225}$ There are numerous letters from Johnson to Dr. Paul Fejos in the Frederick Johnson Papers. Johnson wrote Fejos update reports on progress in the dating method, wrote to discuss the development of a dating "plant," among other projects in which funding would inevitably be necessary.
} 
By late January Libby had not heard from Fejos and, discouraged, wrote to Johnson stating, "I wonder sometimes as to whether our method really has importance and whether we may be wasting our time to a certain extent." A despondent tone, unusual in Libby's correspondence, elicited the "chastising" response from Johnson, who noted that, "20,000 is a very large sum in archaeological circles," thereby subtly commenting on the funding discrepancies amongst scientific disciplines. ${ }^{226}$

More constructively, Johnson also proposed that numerous archaeologists with interest in the development of carbon-14 dating write letters to Fejos to promote the funding cause. Johnson, ever aware of the weight of perception, asked Libby to write the archaeologists himself to avoid the sense that the committee "had assumed control instead of acting in an advisory capacity." 227 The individuals Johnson suggested were Emil W. Haury, Frank H. H. Roberts, Waldo Wedel (President of the SAA), and James B. Griffin.

Libby had also recently suggested expanding the committee by adding the geologist Richard Flint. In the same letter in which Johnson suggested individuals who could assist Libby with Fejos, he also approved Libby's suggestion of Flint, noting that to "bring on" Flint would hopefully bring on the funding power of the Geological Society and that of the National Research Council (due to Flint's position on an NRC committee). ${ }^{228}$ Libby knew Flint to be interested in the dating process due to Flint's questions at the January 9, 1948, Viking Fund dinner. ${ }^{229}$ Johnson sent a letter to Flint, officially asking him to be part of the

\footnotetext{
${ }^{226}$ Frederick Johnson to Willard Libby, January 28, 1949, box 1, folder "Carbon-14 Arnold and Libby 1948 to Aug 1950," FJP.

${ }^{227}$ Frederick Johnson to Willard Libby, January 28, 1949, box 1, folder "Carbon-14 Arnold and Libby 1948 to Aug 1950," “The Frederick Johnson Papers 1948-1968."

${ }^{228}$ Clearly, though Johnson disapproved of the "red tape" of the NRC, he recognized the funding potential therein.
} 
committee on February 23. ${ }^{230}$ From that point on the committee functioned as a joint committee of the AAA and the Geological Society of America. ${ }^{231}$

${ }^{229}$ Marlowe, "W. F. Libby Among the Archaeologists," 1101.

${ }^{230}$ Frederick Johnson to Richard Flint, Feb 23, 1949, box 2, folder "Correspondence with Committee Members" FJP.

${ }^{231}$ Johnson, et al. Radiocarbon Dating, 2. 


\section{CHAPTER 4: THE COMMITTEE COLLABORATORS}

In April, Collier, whose proximity to Libby in Chicago gave him some access to dayto-day events at Libby's laboratory, sent Johnson a letter of some alarm. He explained that if the committee did not immediately come up with a way to provide the lab with large amounts of datable objects that Libby may "listen to other suggestions and demands that keep pouring in to the project." Collier noted, for example, that "Standard Oil of California is dangling some juicy samples, which no doubt they would be willing to subsidize."232 He further reported that the Tree-Ring Laboratory at the University of Arizona had sent a large sample of dated wood to him, which he had dutifully passed on to Arnold. As knowledge of the project grew, so did interest, and competing dating systems and competing sources for samples continued to query Libby.

A year into the project it was clear to Johnson and the other committee members that they alone could not provide the number of samples Libby required to test the dating process. Each member of the committee had utilized their relationship to museum collections to acquire some materials, but far more were needed (in the end, Libby used roughly 250 samples in the period from 1947 to 1951). ${ }^{233}$ The problem went to the very heart of previous methodology; there were difficulties using the types of materials museums had collected in the previous decades. The necessity to destroy samples completely in the testing process (essentially to incinerate them) meant that exhibit quality materials were out of question; this reality severely limited archaeological samples gathered from permanent collections.

\footnotetext{
${ }^{232}$ Donald Collier to Frederick Johnson, April 4, 1949, box 2, folder "Correspondence with Committee Members" "The Frederick Johnson Papers 1948-1968."

${ }^{233}$ Libby, Radiocarbon Dating, 70-96.
} 
Though some museums contained samples of wood/bone/antler/etc in storage with which they were willing to part, often these materials had been gathered in non-stratigraphic digs and therefore were without the accompanying chronological details that would have made them useful samples. Essentially, American archaeology's nineteenth century and early twentieth century disinterest in chronologies, haphazard use of stratigraphy, and preference for exhibit quality pieces constructed a serious obstacle to the integration of carbon-14 dating into Americanist practice.

Johnson faced a difficult decision. He had endeavored to keep the committee small, adding only one member (Flint, a geologist) since the committee's inception. In doing so he had limited the committee to three Americanist archaeologists and a single geologist of North America. Johnson's acumen as a bureaucrat and committee leader lay in his ability to recognize the advantages of staffing committees with a small number of individuals with whom he could work freely. His own explanation of his manipulation of the membership of the CRAR is a case in point. ${ }^{234}$ In addition, when Johnson voiced displeasure with the NRC or other organization he voiced the opinion that cumbersome overstaffed organizations had the tendency to let either message or meaning become lost in "red tape."235 Further, as this thesis concludes, Johnson likely hoped to avoid competing agendas in the leadership of the committee as he endeavored to serve the development of North American chronologies with the dating method.

Johnson's solution was to accept that the committee work with some hand picked non-committee member "collaborators," who would be responsible for providing samples

\footnotetext{
${ }^{234}$ Wendorf and Thompson, 321, quoting Johnson to J. O. Brew, 1973.

${ }^{235}$ For example, Johnson complained of the NRC "things get lost (there) and when action is required it is sometimes difficult to avoid entanglements due to red tape." Marlowe, 21. Johnson expresses a similar opinion, expressing a worry about "red tape" in Johnson to Fejos, December 22, 1947, FJP.
} 
from recent fieldwork. With the development of the collaborator system Johnson hoped to strengthen the committee's gatekeeper status when it came to Libby and the archaeological community by creating a protocol for the presentation of samples that flowed to Libby through the committee members, essentially staving off Libby's use of objects sent to him by unaffiliated practitioners. By handpicking collaborators Johnson could also support the development of chronologies in particular regions. Johnson related his proposition to the committee members, going so far as to explain to Flint that it would no doubt "be necessary to 'screen' applicants.",236

To facilitate this new phase of archaeological assistance a meeting was held in Libby's office at the University of Chicago on April 13, 1949. All committee members, Libby, and Arnold were in attendance. ${ }^{237}$ The meeting's main goal was to establish collaborators and to delineate the responsibilities of the collaborators as separate from that of committee members. Despite the statement that collaborators would "have full share of the archaeological part of the task," the release of dates was to remain the prerogative of Libby, Arnold, and the committee. More specifically, the committee concluded that collaborators would be, "responsible for collecting specimens for Libby, for the accuracy of the record of these specimens, and also for their importance with reference to archaeological problems."238

Some of the discussion in the meeting centered on how best to craft the message for collaborators and put out the word before archaeologists left for the field for the summer.

\footnotetext{
${ }^{236}$ Frederick Johnson to Richard Flint, February 23, 1949, box 2, folder "Correspondence with Committee Members" FJP.

${ }^{237}$ Frederick Johnson to Willard Libby, April 8, 1949, box 1, folder "Carbon-14 Arnold and Libby 1948 to Aug 1950," FJP. Also, Willard Libby to Richard Flint, April 25, 1949, box 1, folder "Carbon-14 Arnold and Libby 1948 to Aug 1950," FJP.

${ }^{238}$ Minutes of Meeting, Committee on Radioactive Carbon-14, Chicago, April 13, 1949, box 2, FJP.
} 
Libby and Arnold explained that two or three samples from the same site or region would serve this phase of the project best. Their thought was that samples from the same stratigraphic layer and from a singular site would offer a "check" on the process because they should, theoretically, provide dates that roughly coincide with one another. Similarly, objects from the same site that were pulled from two or three related stratigraphic layers may also add another helpful "check" to the process in that chronological relations of objects shown by stratigraphic placement would hopefully be reflected in the carbon-14 dates of those artifacts. $^{239}$ Libby's clear concern was the inter-disciplinary goal of the project: the development of the dating method. Yet, Johnson and the committee also sought to further their intra-archaeological goal, that of utilizing the testing to develop chronologies, particularly those which could shed light on North American migrations. Johnson went as far as to admit the secondary goal in the archaeological commentary to Libby's 1952 publication Radiocarbon Dating, stating, "The primary purpose [of providing samples] was to aid in the development of the method ... however, it was hoped that significant chronological data, useful in many ways, would be produced." 240 The decision to work towards chronologies was served by the use of test samples provided from the stratigraphy of modern fieldwork, and this fact provided a further motivation for the collaborator phase.

The committee's hope to use testing phase data to develop chronologies relays a number of presuppositions and concerns (or lack thereof) regarding the testing phase of the process. First, it related a confidence that the dating system would ultimately prove accurate, and that Libby would verify, or "sign off" on the accuracy of the process (Johnson made it

\footnotetext{
${ }^{239}$ Donald Collier to Frederick Johnson, April 4, 1949, box 2, folder "Correspondence with Committee Members" FJP.

${ }^{240}$ Johnson's comments in Willard Libby, Radiocarbon Dating, 98.
} 
clear that only Libby may conclude when the testing phase has ended and whether or not the method was ultimately accurate). ${ }^{241}$ More to the point, the committee's application of test data to chronologies exhibited a lack of concern for differing levels of accuracy of assays produced during the testing phase. Libby used the tests of the period to calibrate equipment and improve methods. He employed a number of different chemical treatments of samples through the period (developing differing protocols for different organic materials), made modifications to the counting device and radiation shield(s), as well as dealt with "leaks" and issues of "contamination," that deemed some dates invalid. ${ }^{242}$ Libby did keep the committee abreast (through letters to Johnson) of major developments during the testing phase and Johnson appears to have taken each development as proof of the process's further precision, despite Libby's contrary assertions. ${ }^{243}$ As early as September of 1949 Johnson stated, "it is true that the dating system seems to be rather foolproof."244

Johnson was committed to the collaborator system sometime in early April, 1949. Even before the April meeting date Johnson contacted Libby with a suggestion for three

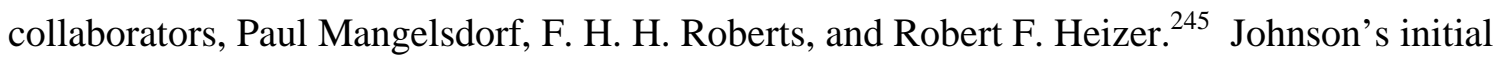
choices gave evidence of his preference for Americanist archaeologists, all three of which

\footnotetext{
${ }^{241}$ Memorandum To Collaborators Working on the Carbon-14 Program and to Others Concerned, dated June 30," 1949, box 1, FJP. Johnson's contention that Libby would decide what the testing phase needed and when it was to be over is also made apparent though the tenor of Johnson's questions concerning the progress of the project in numerous letters.

${ }^{242}$ Libby discusses his various chemical treatments in detail in Radiocarbon Dating "Preparation of the Sample," 42-51. Also in that volume is a discussion of the effect of leaks on the counting method, 67. The largest "contamination of the apparatus" occurred in the spring of 1950 and nullified a number of dates: Johnson to Libby, May 25, 1950, FJP.

${ }^{243}$ Libby to Johnson, April 6, 1948, box 1, FJP. Collier to Johnson, December 30, 1948, box 1, FJP. Also, and undated draft of a letter Johnson to Fejos (probably December 1948), box 1, FJP.

${ }^{244}$ Johnson to Kenneth Macgowen, September 12, 1949, folder “L-P Carbon-14 1948-Aug 1950,” FJP.

${ }^{245}$ Frederick Johnson to Willard Libby, April 8, 1949, box 2, folder "Carbon-14 Arnold and Libby 1948 to Aug 1950," FJP.
} 
were best known for their work on the North American continent: Mangelsdorf was a botanist who studied maize in Mexico, Roberts was the American director of the Smithsonian's River Basin Survey (a colleague and friend of Johnson from the CRAR), and Heizer worked in Nevada and California.

Johnson, Collier, and Rainey began to contact archaeologist collaborators immediately after the April meeting-By early May the collaborator list was:

Early man-Frank H. H. Roberts, Jr.

Peru-Junius Bird

Geology—Richard Flint

Valley of Mexico- Helmut de Terra

Mesopotamia and Western Asia-R. J. Braidwood

Scandinavia and Western Europe-Hallam Movius.

Yukon-Frederick Johnson

California/Oregon-Robert Heizer

Hopewell—James B. Griffin

The Midwest-Major William S. Webb. ${ }^{246}$

By the end of May there were roughly 35 collaborators. ${ }^{247}$ Judging from the list of collaborators generated by Johnson, Collier, and Rainey, their preference was, whenever possible, to collaborate with one of the foremost practitioners working in defined regions. Each choice was a well-published practitioner who had worked to develop relative chronologies. The wisdom of this set of criteria is of course obvious, based upon the committee's interest in developing inter-related chronologies for North America. A couple of choices were political: Helmut de Terra was chosen, in part, because his collaboration had been one of the conditions of Viking Fund money awarded for work in $1949 .^{248}$ Likewise, Braidwood was certainly a well-respected Middle East archaeologist, but his inclusion no

\footnotetext{
${ }^{246}$ Johnson to Fejos, May 3, 1949, box 1, FJP.

${ }^{247}$ Libby to James Thorpe, May 26, 1949, box 1, FJP.

${ }^{248}$ Johnson to Fejos, May 3, 1949, box 1, FJP. The Viking Fund most likely sought to aid one grant recipient (de Terra) with the terms written for another grant (Libby and the CRC14).
} 
doubt helped smooth over some lingering conflict with the University of Chicago Oriental Museum and anthropology department.

Each collaborator was chosen only if they were willing to adjust their field procedures to facilitate the proper collection and transport of uncontaminated samples. This meant that participants would have to carefully collect more than one sample from a series of stratigraphic levels and note their place related to one another, to provide control group samples for each set. Samples could not be prepared in commonly used ways for transport (such as placing them in denatured alcohol or coating them with wax or other substances for preservation) because the addition of organic compounds would, in most cases, alter the carbon-14 levels in the samples. The archaeologists in question also had to be willing to part with (for destruction) numerous organic objects of necessary size that had been recovered from a site. Estimates of the age of the sites developed by stratigraphic comparison, artifact comparison/cultural age, or a combination of these and other non carbon-14 age measurements were necessary for the verification of carbon-14 results.

While Johnson, Collier and Rainey worked to develop lists of archaeologist collaborators, Richard Flint set about contacting geologists on his own. His autonomy speaks to a number of structural realities in regard to the committee and perhaps to Johnson's preoccupation with archaeological concerns. Flint was, for example, from time to time referred to in correspondence as the committee's liaison to the NRC and the American Geological Association, pointedly noting that he was the only committee member who was not a member of the AAA. In some ways, though Flint was a member of the committee, his autonomy and status are reminiscent of that of Libby and Arnold, who were technically not members of the committee but attended committee meetings and functioned as a sort of liaison to a non-archaeological aspect of the project. 
Flint eschewed the "screening" method employed by other committee members and, despite Johnson's fear that the committee would be "besieged by requests," made a general call for collaborators at the NRC April 23rd meeting of the Division of Geology and Geography. ${ }^{249}$ Flint read a statement at the meeting explaining the limits of carbon-14 dating, the need for samples, and the requirements of collaboration. He also set parameters for the type of material that could be dated and gave sample specifications (size/weight requirements) for each type of organic material. ${ }^{250}$

Collaborators collected samples through the summer of 1949 , and sent them to members of the committee. Materials were gathered from collaborator's own excavations and sometimes from other archaeologist's sites in the same region and sent to collaborators. Libby and Arnold tested the objects and returned the data to the committee. The committee then released the dates to collaborators on a mimeographed list, meant only for collaborator viewing. Mimeographed copies of the dates were sent to all collaborators on at least five separate occasions. ${ }^{251}$ As Johnson explained, these lists were sent to collaborators so that they may provide an archaeological critique of the accuracy of the dating process, but the existence of the lists and their confidential status warrants some analysis. In theory, until the release of Libby's findings, assay dates were only to be known by the committee and collaborators, creating an interesting hierarchically tiered relationship in Americanist archeology, moderated by the committee. In June, Johnson wrote a "Memorandum to Collaborators" which contained two major points: that "considerable control over the

\footnotetext{
${ }^{249}$ Frederick Johnson to Richard Flint, February 23, 1949, box 2, folder "Correspondence with Committee Members," FJP.

${ }^{250}$ Richard Flint to Willard Libby, April 18, 1949, box 1, folder "Carbon-14 Arnold and Libby 1948 to Aug 1950," FJP. Flint sent a copy of the call for materials to Libby.

${ }^{251}$ Frederick Johnson, “Radiocarbon Dates and their Use,” American Antiquity 21 (1956), 313.
} 
announcement of dates will have to be exercised by Libby and Arnold, the collaborators, and the Committee;" and that "Libby and Arnold are the sole judges concerning when dates are ready for release." 252 Johnson and the committee had been charged with providing samples to Libby, but as that task was shifted to the collaborators themselves, the goals of the committee realigned towards promotion of the dating process in archaeological circles and release of Libby's findings.

Johnson hoped to control the release of dates and to allow the committee to release commentary that would accompany the official release, and Collier and Johnson discussed this ideal scenario in correspondence in early June. ${ }^{253}$ Yet Johnson quickly realized that controlling the release of Libby's testing dates was an insurmountable task. The collaborator phase meant a higher level of exposure for the project within the discipline of archaeology, and collaborators leaked dates to colleagues. Rumors and conjecture about the project grew, as well as anger regarding the special status of collaborators. On June 13 Johnson explained the situation to Libby:

In the archaeological field, at least, there are a number of misunderstandings most of which come from reasonable people who are puzzled concerning the ends and aims of this whole business. ${ }^{254}$

But by the end of the year Johnson's tone had changed to one of alarm. He wrote,

from the archaeological point of view, the situation in regard to carbon-14 is getting out of hand. At the moment a number of unfortunate and erroneous rumors are flitting about the country and some of these threaten to become serious. They are beginning

\footnotetext{
252 "Memorandum to Collaborators Working on the Carbon-14 Program and to Others Concerned, dated June 30," 1949, box 1, FJP.

${ }^{253}$ David Collier to Frederick Johnson, June 10, 1949, box 1, folder "Correspondence with Committee Members," FJP.

${ }^{254}$ Frederick Johnson to Willard Libby, June 13, 1949, box 1, folder "Carbon-14 Arnold and Libby 1948 to Aug 1950," FJP.
} 
to affect ideas concerning chronology. . . No one knows what is right but everyone has an opinion which he considers to be authoritative. ${ }^{255}$

The difficulty was to some extent fomented by the lack of widely accepted chronologies in Americanist archaeology. The first half of the twentieth century had seen the development of a number of competing chronologies regarding both inter-regional and intra-regional cultural diffusion and migratory patterns. With the development of carbon-14 dates, some Americanist archaeologists became concerned that the collaborators, who had access to carbon-14 date lists, would have an unfair advantage in publishing new, perhaps definitive, chronologies. Such an advantage could prove career making should carbon-14 dating prove accurate. Johnson found himself at the center of a few such conflicts. For example, Frank H. H. Roberts, director of River Basin Surveys and project collaborator wrote Johnson in May of 1949 to complain that fellow collaborator, “[James B.] Griffin intends to keep everything quiet and then come out with a complete revision of his archaeological picture on the basis of the material without including or giving the men who furnished the materials chance to play a part in the announcement." He explained that it was because of this fact that many in the region "refused to cooperate or send in material." 256 Johnson had told collaborators that they should not publish Libby's dates for the time being, but some collaborators had utilized the dates to re-organize their chronologies.

Distrust in regard to the way the carbon-14 question was being handled fueled a number of general complaints about carbon-14 dating. In an interesting turn, some commentators expressed dissatisfaction with the coming encroachment of the physical

\footnotetext{
${ }^{255}$ Frederick Johnson to Willard Libby, box 1, folder "Carbon-14 Arnold and Libby 1948 to Aug 1950," Jan 26, 1950, FJP.

${ }^{256}$ Frank H. H. Roberts, Jr., to Frederick Johnson, May 20, 1949, box 1, folder Q-T Carbon-14 1948 Aug 1950, FJP.
} 
sciences into archaeology. Duncan Strong, one of the most influential archaeologists of the early twentieth century and proponent of pottery shard dating techniques, perhaps had the potential for the overturning of his own chronologies in mind when complained that carbon14 dating would "turn us all [archaeologists] into damn chemists." 257 Similarly, commentators in a 1951 Mississippi Valley archaeology meeting published report concluded, "we stand before the threat of the atom in the form of radiocarbon dating," and "this may be the last chance for old-fashioned-uncontrolled guessing."258

Johnson dealt with a number of other complaints related to the collaborator system, including a heated dispute over regional demarcation amongst collaborators. Webb (collaborator: Midwest) and James B. Griffin (collaborator: Hopewell) disagreed about who had authority over the production of samples in the Midwest. Johnson wrote to Don Collier of the dispute, noting it to be a case of "the sometimes childish competition which has developed in the region since the war." 259

In November 1949 Johnson reported to the AAA annual meeting that roughly sixty samples had been tested to that point. ${ }^{260}$ Despite the difficulties Johnson clung to two distinct

\footnotetext{
${ }^{257}$ Marlowe, "Year One,” 21. Marlowe's source for Duncan Strong January 9, 1948, was Lisa Osmundsen, Oral Interview, May 4, 1981.

${ }^{258}$ In Philip Phillips, James A. Ford, and James B. Griffin, “Archaeological Survey in the Lower Mississippi, 1940-1947," Peabody Museum of American Archaeology and Ethnology, Papers, 25. Cambridge Massachusetts. Quoted in Lyman, et al., 184.

${ }^{259}$ Johnson to Collier, June 13, 1949, box 1, folder “Correspondence with Committee Members," FJP. Collier's letter of June 10 explained how he settled the dispute by re-assigning some specific samples to Webb at the University of Kentucky.

${ }^{260}$ Johnson's "Report of the CRC14 at the November 16'49 AAA meeting," box 1, "Correspondence with Committee Members," FJP. June 23 Johnson was appointed executive secretary of the AAA and wrote to Libby to note that he was going to seek expenses for those working for the AAA. "I suspect that my ideas concerning the relationship between cash and bona fide projects are not too far from yours." Frederick Johnson to Willard Libby, June 23, 1949, box 1 "Carbon-14 Arnold and Libby 1948 to Aug 1950," FJP.
} 
hopes for the committee in the coming year: that the committee would release a report to accompany Libby's release of dates, and that the committee would endeavor to create a testing facility aligned with a professional organization (like the AAA) so that dating may continue in the service of the integration of American regional chronologies.

\section{Other Laboratories}

In May of 1950 Johnson wrote Libby to alert him to the development of other testing laboratories. He stated:

It may interest you to know that T. M. N. Lewis and Madeline Kneberg, archaeologists at the University of Tennessee, have been very annoyed because they have not been asked to supply samples. The reasons are due to conditions having a long, complicated, and not too savory history. Anyhow, they claim that they are going to approach the department of Physics at the University for the purpose of having a machine constructed at Knoxville. ${ }^{261}$

Other laboratories were soon initiated at numerous schools around the country. By late November 1949 Johnson became aware that the University of Michigan had set up a dating apparatus and was perhaps ready to begin dating samples. James B. Griffin was at the University of Michigan and it is most likely that his early dissatisfaction during the skirmish with Webb over collaborator authority contributed to his department's support of their own program. ${ }^{262}$ Johnson wrote to Libby about the situation, stating that the University of Michigan should release dates as they see fit, but if they were to date the same object as

${ }^{261}$ Johnson to Libby, May 25, 1950, box 1, “Carbon-14 Arnold and Libby 1948 to Aug 1950,” FJP.

${ }^{262}$ Griffin to Johnson, May 21, 1949, box 1, folder, “A-G Carbon-14 1948-Aug. 1950,” FJP. Griffin wrote Johnson to announce the project. He wrote, "[Dr. Richard ] Crane is the individual who is going to start work setting up a carbon-14 experiment at the University which we trust will eventually became part of a broad University program of study in peace-time uses of atomic radiation." Horace Richard Crane was part of the University of Michigan physics department from 1934 to 1978. http://www.ur.umich.edu/0607/May07_07/obits.shtml, accessed December 15, 2009. 
Libby's team that the "release of dates should be by mutual agreement." 263 The development of another facility was unwelcome news to Johnson for two reasons: 1) it meant that the idea of a centralized dating facility was at risk, 2) it meant that the committee had no direct ability to suppress the release of dates by another physicist or physical chemist, and the need for Johnson to release dates for their work became ever more urgent.

Johnson's interest in a centralized dating facility was not served by the development of other facilities, particularly those begun in academic settings. Yet Libby's interest in transparency and ran counter to Johnson's concerns, and he continued to support concurrent work on carbon-14 dating by other scientists, notably by continuing to allow access to his laboratories and by publishing detailed descriptions of his theories and apparatus. Libby's book Radiocarbon Dating (1952), relayed his interest in concurrent research in detail, and was written to "contain the answers to most of the questions which will occur to an investigator constructing and operating equipment for the measurement of dates by the radiocarbon method." ${ }^{264}$ Furthermore, over the course of the summer and fall of 1949, Libby extended the invitation to geologists and archaeologists to his laboratory, some of which were neither collaborators nor committee members. Perhaps the best indication of Libby's intentions was his comment, "I don't want to be the pope of archaeological dating."265

With Johnson's preferred methodology constantly thwarted he began complaining about Libby to colleagues. Johnson wrote to anthropologist and project collaborator Robert Heizer (California/Oregon):

\footnotetext{
${ }^{263}$ Johnson to Libby, November 22, 1949, box 1, "Carbon-14 Arnold and Libby 1948 to Aug 1950," FJP.

${ }^{264}$ Libby, Radiocarbon Dating, v-vi.

${ }^{265}$ Arnold, 8 .
} 
Libby is one of the most able scientists I have ever come in contact with. There are, however, some rather discouraging 'holes' in his knowledge. He works himself blue in the face trying to increase the accuracy of the dates, but I am sure that he doesn't have the foggiest idea of their significance to other people. ${ }^{266}$

In a section revealing of the complex yet intimate relationship the men shared, Johnson complained to European collaborator Hallam Movius, "every once in a while I scold Libby, plead with him and threaten him, but it does no good."267

There is a manner in which Johnson's difficulty with Libby lay in differing agendas: one a bureaucratic interest in structuring the dating method for archaeological use (Johnson), and another an interest in discussion and analysis of the dating method informed by a sense of peer review and transparency. Perhaps the best example of the distance that separated Libby and the committee's methodologies occurred in the January 1951 committee meeting during the discussion of the publication of dates in Libby's book:

It was suggested that Libby's book quote only a selected number of samples and dates. These to be chosen in "sets" which were well authenticated stratigraphically. One purpose of this, it was thought, was to provide evidence of the validity of the method. . . . Libby believed, however, that there was a need for a full listing of all dates. Such would emphasize a number of important features such as the scatter in results which are used by physicists and others in judging the method. ${ }^{268}$

In this case, Libby's concern for transparency placed him at odds with a bureaucratic interest in the promotion of the accuracy of the dating method. In some ways his singular role as scientist made his decisions simpler than those of the committee members. Johnson and the committee members maintained duel roles: that of scientists and administrators. These duel

\footnotetext{
${ }^{266}$ Johnson to Robert Heizer (Dept of Anthropology U.C. Berkeley) March 7 1951, box 2, Carbon-14 H-K Sept 1950, FJP.

${ }^{267}$ Johnson to Hallam Movius, Oct 5, 1951, Box 2 Carbon-14 L-P Sept. 1950, FJP.

${ }^{268}$ CRC14 meeting minutes, January 30 1951, Box 2 folder: Carbon-14: Minutes of Meeting, FJP.
} 
roles could at times seem to be at odds. Like other scientist/bureaucrats with authority over aspects of big science projects, Johnson and the committee were invested in the success of the project understood within the framework of the committee's goals. They relied on the work of other scientist (in this case, scientists in another field) to provide verification of that success. They necessarily worked under the assumption that the project as a whole would prove valid.

Johnson's concern that Libby's policy of laboratory transparency and access would cause schisms in the archaeological community was not entirely unfounded. Sometime after July 1950, Johnson was forwarded a letter originally written by Southwest archaeologist Harold S. Gladwin, who had toured Libby's facility and was dissatisfied with the conditions in the lab. He described Libby's laboratory as:

... an extremely cramped and messy lab in which experiments were being conducted. Their office was a small room, about $15 \times 20$, in the one Chemical Laboratory on the campus of the University of Chicago. The place stank like a glue factory and as one walked down the corridor between the offices, there was a sign on every door warning you not to come in without mask or goggles. ${ }^{269}$

Gladwin took his newfound fears to Ernest Watson, dean of faculty at California Institute of Technology, explaining that he was "apprehensive that one institution might run away with the ball without adequate checks on the results." He further worried that the Chicago laboratories would not be receiving proper readings because of the number of experiments being done in such close quarters would contaminate one another. He notes that his conversation with members of the Cal Tech physics department left him with the opinion that "my doubts about some of the work at the University of Chicago were not without substance"

${ }^{269}$ Harold S Gladwin to V. A. Kidder, July 18, 1950, folder: H-K Carbon-14 1948 to Aug 1950, FJP. This letter was forwarded to Johnson (most likely by Jo Brew) with note: "Dear Fred, for your confidential information." 
because experts at $\mathrm{Cal}$ Tech believed, "that it would be impossible to shield a small office adequately from radioactive experiments." ${ }^{, 70}$ Johnson answered this charge with a disarming bit of honesty: "the problem of contamination is so 'tricky' I do not want to get entangled with it - after all the whole process mystifies me."271 In the end, the faculty at Cal Tech did some carbon-14 dating tests under 150 feet of concrete at the Morris Dam to shield their apparatus from radiation.

Libby happily met with archaeologists at his lab, and was most likely the major source of "leaked" dates through the end of the year (when a mimeographed copy of the dates was distributed to collaborators). Furthermore, Libby was clearly still dating materials for some individuals who were not collaborators, thereby creating a sort of "inside" and "outside" track, or an official and unofficial process by which materials were dated. ${ }^{272}$

Facilities were soon in the works at Berkeley and Columbia University to join those at the University of Chicago and the University of Michigan. By 1953 there were at least five operational facilities providing dates (University of Michigan, University of Chicago, Columbia University, one in England and one in Denmark). There were also facilities in production but not yet operational at the University of Pennsylvania, Yale, the University of Arizona, and the University of California. ${ }^{273}$

\footnotetext{
${ }^{270}$ Harold S. Gladwin to V. A. Kidder, July 18, 1950, folder: H-K Carbon-14 1948 to Aug 1950, FJP.

${ }^{271}$ Johnson to Kidder, July 28 1950, H-K Carbon-14 1948-Aug 1950, FJP. Perhaps germane to the discussion, Galdwin was a Southwest region archaeologist who had worked extensively with the "rival" dendrochronology.

${ }^{272}$ Johnson to Libby, October 13, 1950, folder: “Carbon-14 Sept 1950: Committee Members,” FJP.

273 Johnson to Kenton Keller, Research Physics Geophysical Institute of the University of Alaska, (undated-1950?), box 2, Carbon-14 H-K Sept 1950, FJP.
} 
In the March 1950 committee meeting Johnson discussed the possibility of opening a dating facility, stating: "Libby will furnish all blueprints and necessary detailed information. It will be necessary to have a physicist or someone familiar with the process to oversee the running of the machine." ${ }^{, 74}$ The costs to run the facility as well as personnel was discussed, though the facility was not set up, perhaps due to a lack of funding. Johnson continued to attempt to develop a central dating facility as late as 1955. In June of 1955 he wrote Arnold, asking him, "Would you be willing to help establish and supervise a radiocarbon laboratory located in Princeton [where Arnold was then a professor] but fully supported by outside funds?"275 Despite Arnold's admission that he, Suess, and Libby, "all agree that a suitable carbon-14 laboratory for archaeologists has yet to come in to existence," Johnson and Arnold produced no lab. ${ }^{276}$

\section{Release of Dates, Dismissal of the Committee (January 1950-January 1952)}

By 1950 the rumors, misunderstandings, and infighting in archaeology were a central concern for Johnson. Inherent in Johnson's attempt to publish definitive dates at the earliest possible time were these very concerns. At stake was the functionality of the professional organizations Johnson served and believed in — the SAA and AAA—which required a level of cordiality amongst members to function adequately. Johnson's promotion of the authority of professional organizations was not only grounded in an attempt to preserve and promote

\footnotetext{
${ }^{274}$ CRC14 Meeting Notes, March 16, 1950, Box 2 folder: “Carbon-14: Minutes of Meeting,” FJP.

${ }^{275}$ Johnson to Arnold, June 23 1955, box 3, folder "Radiocarbon-Archaeological Laboratory," FJP.

${ }^{276}$ Arnold to Johnson, July 6, 1955, box 3, folder “Radiocarbon-Archaeological Laboratory,” FJP.
} 
the authority and prestige of the organizations, but also to preserve the ability of these organizations to serve archaeologists.

Johnson wrote to Libby January 4, 1950 explaining:

for some time I have been thinking seriously of the advisability of getting some definite data concerning the general project published. ... Your project and the general program has caused a tremendous amount of discussion in America and people are becoming misinformed or only partially informed concerning what has been achieved. ${ }^{277}$

Later in the month Johnson wrote again, with more urgency, arguing for a definitive dates. ${ }^{278}$ Johnson had hoped to have each collaborator co-write with Libby an article to accompany each series of dates, but he was now balancing his interest in furthering the committee's and collaborator's involvement with the urgent need for publication. Libby was away in California and Arnold answered Johnson's letter, subtly suggesting that the chaos could even be noted in the physics end of the project: "we certainly have seen plenty of evidence of misinformation on the part of archaeologists about our project in the last month or two." ${ }^{279}$ A mimeographed distribution of dates had gone out to collaborators January 1, perhaps under the assumption that if there were dates being shared at least the committee could eliminate unnecessary errors and confusion by providing all the collaborators with an updated list. ${ }^{280}$

Johnson continued to struggle to keep dates from being released. In March 1950 Johnson wrote University of Oklahoma archaeologist Robert E. Bell explaining "I am sorry to have to request in the name of the Committee that a discussion of carbon-14 dates be

\footnotetext{
${ }^{277}$ Johnson to Libby, January 4 1950, box 1, folder 1, Carbon-14 Arnold and Libby 1948 to Aug 1950, FJP.

${ }^{278}$ Johnson to Libby, January 26 1950, box 1, folder 1, "Carbon-14 Arnold and Libby 1948 to Aug 1950," FJP.

${ }^{279}$ Arnold to Johnson, January 6, 1950, box 1, folder 1, "Carbon-14 Arnold and Libby 1948 to Aug 1950," FJP. It is interesting to note that Arnold was able to open Libby's mail (at least that sent by Johnson) while Libby was away.

${ }^{280}$ CRC14 Meeting Notes, March 16, 1950, Box 2 folder: “Carbon-14: Minutes of Meeting,” FJP.
} 
dropped from the program for the Annual Meeting of the Society." In a similar fashion he noted that biologist Harold Cahn's presentation on the carbon-14 process at the same event would have "no official sanction whatsoever." Interestingly, this statement points to the committee as far more than advisory and collaborative. Johnson went so far as to suggest to Bell that one goal of the committee was to evaluate the carbon-14 process, explaining, "It was for this purpose, mainly, that the present program was inaugurated."

By May the committee had still not established a date for publication and it was clear to Johnson that some archaeologists and geologists were preparing to present new work that referenced the leaked dates. Richard Flint wrote to Johnson to warn him of just such a presentation at a November 1950 geology conference. Johnson, characteristically, argued that because the presentation had to do with geological dates it was Flint's call about whether or not to stifle the presentation. ${ }^{281}$

Johnson was further able to discourage the publication of articles that dealt with prereleased carbon-14 dates in the SAA journal American Antiquity through his relationship and correspondence with the editor, archaeologist Jesse D. Jennings. After corresponding with Jennings, Jennings complied with Johnson's request to keep dates out of the pages of American Antiquity and wrote,

I have also deleted some references to specific carbon-14 dates in "Notes and News" and one or two articles. This I did in order to keep the pages of Antiquity [sic] free from carbon-14 speculations until the cold dope could be provided by you and the committee. It seems to me that American Antiquity as the 'voice' of the society should be rather conservative in this matter. ${ }^{282}$

\footnotetext{
${ }^{281}$ Johnson to Flint May 16, 1950, box 2, folder “Correspondence with Committee Members,” FJP.

282 Jesse D. Jennings (University of Utah) to Frederick Johnson, Dec 12, 1950, box 1, folder, Jennings: Carbon-14, FJP.
} 
It is possible that Johnson was able to apply similar influence over AAA publications from his position as executive secretary of that organization. ${ }^{283}$

Libby produced the first "authoritative list [of carbon-14 dates] for general use" in a "pamphlet" released September 1, 1950. Tellingly, this list was still only intended for "those who had contributed samples and people who were collaborating with the committee," enlarging the circle of intended viewers only slightly. Johnson did note that, despite the mandate, the list was "widely circulated." 284

By October 1950, Johnson had not yet been able to produce an archaeologically sponsored release of dates (with accompanying collaborator commentary), and his plans for a central dating facility were stalled. Despite these facts, Johnson wrote Libby a letter in arguing the committee should be disbanded:

I think it is a good idea to discharge the present committee and I will make the formal suggestions to the Anthropological association and the Geological Society of America unless I hear complaints from you or the other committee members. ${ }^{285}$

Johnson's attempt to disband the committee signaled the end of Johnson's hope that an expanded version of the committee would administer a carbon-14 dating facility, and perhaps signaled Johnson's interest in attempting a new tack for the development of the facility. Certainly, Johnson hoped that Libby's release of the dates in September signaled the end of the testing phase for carbon-14 dating. Despite Johnson's request, Libby wrote Johnson back expressing his need for the committee for one more year. ${ }^{286}$ The interdisciplinary

${ }^{283}$ Johnson to Libby, June 23, 1949, box 1, folder 1, "Carbon-14 Arnold and Libby 1948 to Aug 1950," FJP.

\footnotetext{
${ }^{284}$ Johnson et al., "Radiocarbon Dating: A Report," 3.

285 Johnson to Libby, October 13, 1950, box 1, folder, “Carbon-14 Sept. 1950 Committee Members," FJP.

${ }^{286}$ Johnson to Collier, Oct 18, 1950, box 1, folder, “Carbon-14 A-G September 1950,” FJP.
} 
collaborators had agreed that the testing phase would continue until Libby and Arnold decided it was over, yet Johnson was not above guessing as to when this would be. No doubt, some of the reason for Johnson's interest in a timely conclusion to the testing phase was due to the difficulties involved in controlling the circulation of the carbon-14 dates; these difficulties were fomented by Johnson and the committee's own assertions that the dates and dating method would prove accurate.

Generally, the dates held different meaning and potential use for the archaeological side of the testing than from the physical/chemical. For Libby and Arnold the dates were each a yardstick by which the accuracy of the mechanism was to be measured. For Johnson and the archaeologists the dates were data themselves, to be applied to scientific questions outside the scope of the testing process. ${ }^{287}$ Libby warned against this methodology, expressing that the process was not yet "accurate" during the testing phase; as late as April of 1950 had serious doubts about the success of the project. ${ }^{288}$ Many of the dates made in this era would in fact be shown to be inaccurate (victims of the not yet detected Suess and de Vries effects, among other factors) and would be recalibrated against dendrochronology dates starting in the early 1950 s. $^{289}$

\footnotetext{
${ }^{287}$ There are interesting questions surrounding when experiments end. See Pete Gallison, How Experiments End (Chicago: University of Chicago Press, 1987). Johnson hoped that the experimental phase of radiocarbon dating would end conclusively so that data could than be collected in the service of archaeological chronologies. In that case, radiocarbon dating would become a tool to archaeologists, which could be relied on for accurate measurements.

${ }^{288}$ Libby to Johnson April 6 1950, box 1, folder 1, “Carbon-14 Sept. 1950 Committee Members," FJP .Libby's apparatus also became "contaminated" during the period invalidating some dates most likely already leaked and perhaps even on a mimeographed list.

${ }^{289}$ Han Suess pointed out that the ratio of carbon-14 in the atmosphere verses that of stable carbon-12 has been greatly affected by the burning of fossil fuels. Therefore radiocarbon dates garnered from artifacts post industrial revolution must be calibrated for the Suess effect. Similarly Hessel de Vries noted that the amount of cosmic radiation entering the atmosphere has actually fluctuated due to stellar variations and therefore the de Vries effect has been noted and requires the calibration of dates.
} 
Johnson's attempt to disband the committee in no way signaled the end of Johnson's interest in carbon-14 dating, nor an end to his central presence in developing the dating method for archaeology, only a clear hope that the committee's mission of assisting in the testing phase was complete. Johnson, in fact would remain an active member of carbon-14 conferences and other aspects of carbon-14 dating application well into the 1960s.

In accordance with Libby's request, the committee remained in place and met in Chicago January 30, 1951. It was decided at the meeting that the initial phase of the committee's work was over, and that the collaborators should at that time be discharged. It was also decided that the committee would change its name to the Committee on Radiocarbon Dating. ${ }^{290}$ From that point on the committee would act as a "clearing house" for samples, meaning it would pass on samples to any of the operating carbon-14 labs, support grant applications, and prepare an "annual or biennial critical review of all the results of all the machines in operation" in a journal with as wide a circulation as possible. ${ }^{291}$

In the April, 1951 American Journal of Science, Flint with a co-writer published the geological carbon-14 dates. ${ }^{292}$ Soon after, in July, Johnson and the collaborators released their report, "Radiocarbon Dating: A Report on the Program to Aid in the Development of the Method of Dating." Libby's book Radiocarbon Dating was released soon after. The two latter publications contained identical announcements of test dates from 1947 to 1950. Johnson wrote the introduction to the archaeological report while Flint, Rainey and Collier,

\footnotetext{
${ }^{290}$ Rainey to Johnson, Jan 18 1951, box 2, “Carbon-14 Q-T September 1950,” FJP.

${ }^{291}$ CRC14 Meeting Notes, January 30 1951, box 2, folder, “Carbon-14: Minutes of Meeting,” FJP.

${ }^{292}$ Richard Foster Flint, and Edward Smith Deevey, "Radiocarbon Dating of Late-Pleistocene Events," American Journal of Science, Vol. 249, (1951) 257-300.
} 
and thirteen collaborators added sections as well. The SAA published the archaeological report, while the University of Chicago Press had published Libby's book.

Generally, by 1951 Johnson had come to hope the committee could soon act to advise archaeologists during the period of application of carbon-14 dating to archaeology's chronological problems. Johnson believed the committee could act as,

... some sort of theoretically impartial body, which could deliver an opinion concerning the validity of the accompanying data or other matters of the sort. The committee would secure such advice from numerous scientists which we would choose. $^{293}$

Johnson set about designing ways in which carbon-14 dates could be used to aid regional chronologies and the development of inter-regional chronologies. The existence of numerous dating facilities (in operation despite Johnson's long held hope for a single professional organization run facility) meant that Johnson felt that the dates produced must be published for ease and consistency in a single publication. He wrote collaborator Junius Bird, stating that the committee could,

... publish dates in a single clearing house. These we would publish regularly in a journal like SCIENCE so that there would be one place where all the information would be assembled. ${ }^{294}$

In this way, Johnson modified his plan of a central "plant" which would have done testing to one in which dates created by different carbon-14 labs would be sent to a central administrative organization for verification, and publication. Yet Johnson faced a challenge finding a professional organization that was willing to commit large amounts of printed space in a publication for the steady stream of newly produced carbon-14 dates. During the search, Johnson dismissed recommendations that he talk to the Smithsonian or Carnegie foundation, believing it "debatable" that the Smithsonian was a neutral, unbiased organization, and

\footnotetext{
${ }^{293}$ Johnson to Junius Bird, October 19, 1951, box 1, folder, “Carbon-14 A-G September 1950,” FJP.

${ }^{294}$ Johnson to Junius Bird, October 19, 1951, box 1, folder, “Carbon-14 A-G September 1950,” FJP.
} 
explaining that the Carnegie foundation was structured in such a way "that it would be difficult, if not impossible," for them to function adequately for the task. ${ }^{295}$

Knowing Johnson's bureaucratic relationship with both the AAA and the SAA he most likely either could not get those organizations to give up print space in their journals or found them, in some way, inadequate for the task. Whatever the reason, Johnson did not acquire a place to print new archaeological dates. Instead, after the dismissal of the committee in January 1952, Johnson created a private company, The Radiocarbon Dates Association, to create punch cards of archaeological dates that were in turn mailed to subscribers. ${ }^{296}$ Essentially, the company collected carbon-14 dates produced at numerous dating facilities and produced card sets with that data that could be collated in different sets (by year, by region, etc) with punch card technology. In this venture it seems Johnson had come full circle; his metaphorical conceptualization that an archaeologist "should be prepared to discharge his duties completely and efficiently in much the same way as a small business is run" manifest in Johnson running a small business which manufactured an archaeological tool. ${ }^{297}$ It was a venture he and colleague Douglas Byers ran out of their offices at the Andover Academy until 1964, when propriety rights were sold to the Quincy Mail Advertising Agency.

${ }^{295}$ O.G.S. Crawford (editor: Antiquity) to Frederick Johnson, August 28, 1952, box 1, folder, "Carbon14 A-G September 1950," FJP.

${ }^{296}$ Frederick Johnson to R. M. Chatters, Washington State University, April 28, 1965, box 4, Folder, "Invitations, Acceptance, Participants, etc.," FJP. The records of Johnson and Beyer's punch card company (Radiocarbon Dates Association) are in the FJP. In 1958 the journal Radiocarbon was founded to publish date lists as well.

${ }^{297}$ J.O. Brew, et al. "Symposium on River Valley Archaeology," 215. Each commentator in this article had a separate section for comments. The quote falls in Johnson's area of the article. 


\section{CONCLUSION}

At a 1965 Radiocarbon and Tritium Conference, Johnson explained that Libby's development of carbon-14 dating "dropped the equivalent of an atomic bomb on archaeology."298 Similarly, European archaeologist Glyn Daniel ranked the development of the carbon-14 dating system with the nineteenth century discovery of the antiquity of the human species in terms of its impact on practice. ${ }^{299}$ Such views of carbon-14 are two of many in a similar vein—part of archaeology's self directed analysis of the history of practice - that reveal the perceived legacy of Libby's dating method. They impart upon archaeology a methodological schism, emanating from the moment isotope counting techniques descended upon anthropology.

But an analysis of the integration of carbon-14 dating into archaeological practice reveals a continuity of developments central to Americanist archaeology through the period of integration and of continued relevance to present practice. The Committee on Radioactive Carbon-14 stands as a vivid example of the ways in which the field of archaeology had come to be organized by the late 1940s: run by bureaucratic administrators, attuned to the evolving funding landscape of postwar America, aware of the power of organizational affiliations, and aware of the advantages of uniform practice. Furthermore, the interests of the committee members in chronologies and migratory patterns as related to sites in North America reflected the consensus that had formed regarding the problems of Americanist inquiry prior to the development of carbon-14. Contemporary archaeological practice continues to reflect these changes as developed through the first half of the twentieth century.

\footnotetext{
${ }^{298}$ Frederick Johnson, “The Impact of Radiocarbon Dating Upon Archaeology,” 762.

${ }^{299}$ R. E. Taylor, Radiocarbon Dating, and Archaeological Perspective (New York: Academic Press, 1987), ix.
} 
Women's Studies and Sociology professor Jennifer L Croissant discusses the narratives presented of the development of archaeological dating techniques, noting that those produced by "insiders" (members of the archaeological field) are most often "ideographic with only latent analytic potential." 300 She enumerates the ways in which narratives may be utilized to regularize present day practice, perhaps at the expense of details that serve understandings of those outside the discipline. R. E. Taylor (from "inside" the discipline no less), points to the obscuring effect of "subsequent developments in the field" which "can influence what parts of the process [of discovery/development] are recalled, and those that are not." 301 Yet just as obscuring as "subsequent developments" themselves may be the frame by which prior developments are handled by the historian, separated from present practice by a narrative of revolutionary alteration.

It is apparent that Johnson and Daniels are correct and carbon-14 dating greatly changed archaeology: it forced field practitioners to eschew preservation and cleaning techniques (solvents, waxes, etc.) which had long been a part of museum oriented practice; it (perhaps counter-intuitively) promoted the greater use of stratigraphy at excavation sites; it made absolute dates possible without astronomical and philological corroboration; it broke down regionality in Americanist practice, allowing for an emphasis on continental migratory models; and it allowed archaeologists to focus upon new theoretical contentions once freed from the burden of contentious relative chronologies. The integration of carbon-14 dating facilitated further uniformity of methods and the need for greater communication between practitioners. Along these lines, Taylor has argued that carbon-14 dating "provided major

\footnotetext{
${ }^{300}$ Jennifer L. Croissant, "Narrating Archaeology: A Historiography and Notes Toward a Sociology of Archaeological Knowledge," in It's about Time: A History of Archaeological Dating in North America, ed. Stephen E. Nash (Salt Lake City: University of Utah Press, 2000), 203.

${ }^{301}$ R. E. Taylor, “The Introduction of Radiocarbon Dating," in It's About Time, 85.
} 
impetus for interdisciplinary and contextual studies in archaeology."302 Collin Renfrew, in discussing European archaeology, expressed a similar opinion that, "until the advent of carbon-14, the continents of the world had been effectively cut off from one another, from the archaeological point of view." ${ }^{303}$ The fact that these changes reflected a maturation of many of the long term goals of Frederick Johnson, and other likeminded administrators, again places carbon-14's legacy under the microscope: was the method integrated into Americanist archaeology because it provided scientific data of consequence, or because it furthered and fostered the professionalization of the discipline? Essentially, was there a sociological aspect to what Colin Renfrew dubs "the first radiocarbon revolution"? 304

Undoubtedly so. Fredrick Johnson and the CRC14 didn't just endeavor to assist in the testing of carbon-14 dating, but also hoped to apply the method to particular difficulties in Americanist archaeology and direct the integration of the method to foster organizational goals. What could be dubbed a "nationalist" or continental agenda under the CRC14 reveals something of Johnson's own particular interests, but also something of the tendencies of a committee working under the AAA or any other nationally configured organization, particularly one that sought funding from government and American philanthropic organizations. Whereas academic departments or international philanthropies may have advanced the assays of other regions (some of them, international), the committee remained interested in Americanist chronologies. Clearly, Johnson focused CRC14 collaboration on American sites, advancing the interests of the membership of the SAA and those members of the AAA who worked primarily in North America. Embedded in Johnson's hope to create a

\footnotetext{
${ }^{302}$ Taylor, Radiocarbon Dating, 144

${ }^{303}$ Renfrew, 61.

${ }^{304}$ Renfrew, 48 .
} 
AAA run carbon dating "plant" was the assumption that the work of carbon-14 dating would transfer to non-physicists and come under the oversight of professional archaeological organizations. It was a position that relayed a belief that inter-disciplinary collaboration was merely the initial phase of the process - the exception, not the rule.

Johnson hoped that the committee would play a role in mediating structures—both physical structures related to the process of dating, and social structures within the profession - hinged on the belief that the authority behind carbon-14 dating would imminently transfer to the professional organizations of archaeology. A wish for proprietary control of the dating process informed Johnson's personal frustrations with Libby's open door policy and interest in developing other dating laboratories. As a consequence of interdisciplinary collaboration, many of Johnson's main goals, including an organizationally run dating facility, and a committee publication of dates in a professional journal, were often in jeopardy of not materializing.

Johnson's attempts to control the release of dates dovetailed with attempts at control of the perception of the dating process, and this ran counter to some of Libby's conceptualizations of necessary transparency. Clearly, the discrepancy between Libby and Johnson's opinion of the level of transparency and openness invokes discussion of the differences between archaeologists and physical scientists in the postwar period. More germane to this thesis, it also invokes a discussion of the differences between scientists actively engaged in committee business and those engaged directly in fieldwork or experiments. It begs the question, if archaeologists generally agree about the importance of the introduction of carbon-14 dating into archaeological practice, what explains the relative obscurity of the CRC14 and its chair Frederick Johnson? 
One can point to the Mathew Effect, noting that discussion of carbon-14 dating inevitably ignores administrative "players" in favor of discussion of the experimenter of record Willard Libby. ${ }^{305}$ This may indeed be the case. One can also note Johnson's dearth of publications related to fieldwork, or his lack of credentials (all but Ph.D. at Harvard).

Johnson's status despite his lack of publications raised the ire of colleagues, most likely those who were threatened by the growing role of administrative scientists. ${ }^{306}$ Yet these realities alone do not explain the obscurity someone like Johnson, who collaborated with the most lauded Americanist archaeologists of the period (Duncan Strong, James B. Griffin, William Webb, among others), who served in powerful positions, and who was an authority on the carbon-14 dating technique for many years after his involvement with the CRC14.

The question may not have a definitive answer. Though it is instructive to note that Johnson's preferred model for Americanist archaeology—as structured under broadly powerful professional organizations—-did not come to pass.

Overall, the fact that carbon-14 dating was embraced by archaeologists worldwide cannot be allowed to obscure the dating method's development at the hands of a physical chemist and a small group of Americanist archaeologists whose actions reflected the greater trends present in Americanist archeology. And their perceptions reflected perhaps as much as their actions. Libby wrote in 1965 ,

\footnotetext{
${ }^{305}$ Robert K. Merton, "The Matthew Effect in Science: The Reward and Communications Systems of Science are Considered," Science 159 (Jan. 5, 1968): 56-63.

${ }^{306}$ Marilyn Norcini, “Frederick Johnson's Canadian Ethnology in the Americanist Tradition," Histories of Anthropology Annual 4 (2008): 107.
} 
Radiocarbon and tritium were born out of a desire to escape reality. The beginning of their birth lay in the travails of the world and of the scientists working in it during World War II- a desire to discover something useless and impractical, something that would be interesting and perhaps insignificant. ${ }^{307}$

The description undoubtedly expresses how characteristics such as practicality and significance lie, so very often, squarely in the eye of the beholder.

${ }^{307}$ Willard Libby, "Natural Radiocarbon and Tritium in Retrospect and Prospect," International Conference Radiocarbon and Tritium Dating: Held at Washington State University, Pullman Washington, June 7-11, 1965, ed. Roy M Chatters and Edwin A. Olson (Washington: Division of Industrial Research, 1965): 745 


\section{SOURCES CONSULTED}

Ahern, J.J. "A Guide to the Frank Gouldsmith Speck, 1881-1950, Papers, 1925 -1937.” University of Pennsylvania Archives, http://www.archives.upenn.edu/faids /upt/upt50/speck_fg_guide.pdf.

American Philosophical Society, “background note,” John Alden Mason Papers 1904-1967. http://amphilsoc.org/mole/view?docId=ead/Mss.B.M384-ead.xml\#bioghist. Accessed June 2010.

Anderson, Ernie C., Willard Libby, Sidney Winehouse, A. V. Grosse, A. F. Reid, and A. D. Kirshenbaum, "Radiocarbon from Cosmic Radiation," Science 105 (May 1947), 576.

Arnold, James R. "The Early Years with Libby at Chicago: A Retrospective." In Radiocarbon After Four Decades: An Interdisciplinary Perspective, ed. R.E. Taylor, A. Long, and R. S. Kra. New York: Springer-Verlag, 1992, 6-12.

Arnold, James R. and Willard F. Libby. "Radiocarbon from Pile Graphite; Chemical Methods for its Concentration.” AEC contract no. W-31-109-Eng-38. Washington DC: GPO, 1946.

Benedict, Ruth. “The Viking Fund.” American Anthropologist 49 (1947): 527-530.

Beyler, Richard, Alexei Kojevnikov, and Jessica Wang. "Purges in comparative Perspective: Rules for the Exclusion and Inclusion in the Scientific Community under Political Pressure." Osiris 20 (2005): 23-48.

Bowman, Sheridan Radiocarbon Dating. Berkley: University of California Press, 1990.

Boyer, Paul S. By the Bombs Early Light: American Thought and Culture at the Dawn of the Atomic Age. New York: Pantheon Books 1985.

Brew, J. O. et al. "Symposium on River Valley Archaeology.” American Antiquity 12 (1947): 209-225.

Buck, Alice. “A History of the Atomic Energy Commission.” Washington: Department of Energy, GPO, 1983.

Burnham, James. The Managerial Revolution: What is Happening in the World. Bloomington: University of Indiana Press, 1941.

Bush, Vannever. "Science the Endless Frontier," Washington D. C.: Office of Scientific Research and Development, 1945.

Byers, Douglas S., and Frederick Johnson. "The Purchase of Archaeological Material." American Antiquity 4, no. 1 (1938): 62-63.

Byers, Douglas S., and Frederick Johnson. "Some Methods Used in Excavating Eastern Shell Heaps. American Antiquity 4, no. 3 (1939): 189-212.

Clagett, Marshall. Ancient Egyptian Science: Calendars, Clocks, and Astronomy. Philadelphia: American Philosophical Society, 1989.

Cohen, K. P., S. K. Runcorn, H. E. Suess, and H. G. Thode. "Harold Clayton Urey 29 April 1893-5 January 1981." Bibliographical Memoirs of Fellows of the Royal Society 29 (1983): 623-659. 
Cole, Jonathon R., and Stephen Cole. Social Stratification in Science. Chicago: University of Chicago Press, 1973.

Crane, Diane. "The Gatekeeper Role in Science: Some Factors Effecting the Selection of Articles for Scientific Journals.” American Sociologist 2 (1967): 195-201.

Creager, Angela N. H. and Maria Jesus Santesmases. “'Radiobiology in the Atomic Era: Changing Research Practices and Policies in Comparative Perspective." Journal of the History of Biology 39 (2006): 637-647.

Creager, Angela N. H. "Nuclear Energy in the Service of Biomedicine: The U.S. Atomic Energy Commission's Radioisotope Program, 1946-1950." Journal of the History of Biology 39 (2006): 649-684.

Croissant, Jennifer L. "Narrating Archaeology: A Historiography and Notes Toward a Sociology of Archaeological Knowledge." In It's About Time: Archaeological Dating in North America, ed. Stephen E Nash. Salt Lake City: University of Utah Press, 2000, 186-206.

Darnell, Regina. Invisible Genealogies: A History of Americanist Anthropology. Nebraska: University of Nebraska Press, 2001.

De Solla Price, Derek J. Little Science, Big Science. New York: Columbia University Press, 1963.

Doel, Ronald E. "Constitution the Postwar Earth Sciences: the Military's Influence on the Environmental Sciences in the USA after 1945." Social Studies of Science 33 (2003): 635-666.

Dunnell, Robert C. "Five Decades of American Archaeology." In American Archaeology Past and Future: A Celebration of the Society for American Archaeology 1935-1985, ed. by David J. Meltzer. Washington: Smithsonian Institute Press, 1986, 23-49.

Fagette, Paul. Digging for Dollars: American Archaeology and the New Deal. Albuquerque: University of New Mexico, 1996.

Ferguson, T. J. "Native Americans and the Practice of Archaeology." Annual Review of Anthropology 25 (1996): 63-79.

Fleming, Stuart. Dating in Archaeology: A Guide to scientific Techniques. London: J.M. Dent and Sons, 1976.

Flint, Richard Foster, and Edward Smith Deevey. "Radiocarbon Dating of late-Pleistocene Events." American Journal of Science 249 (1951): 257-300.

Galison, Peter. "The Americanization of Unity.” Daedalus 127 (1998): 45-71.

Galison, Peter. How Experiments End. Chicago: University of Chicago Press, 1987.

Galison, Peter. "Specific Theory.” Critical Inquiry 30 (2004): 379-383.

Gaudillere, Jean-Paul, and Ilana Lowy, ed. The Invisible Industrialist: Manufactures and the Production of Scientific Knowledge. New York: St Martin’s Press, 1998.

Grosse, A.V. and Willard Libby, "Cosmic Radiocarbon and Natural Radioactivity of Living Matter," Science 25 (July 1947): 88-89.

Griffin, James B. "The Formation of the Society for American Archaeology." American Antiquity 50, no. 
2 (1985): 261-271.

Guthe, Carl E. "Reflections on the Founding of the Society for American Archaeology." American Antiquity 32 (1967): 433-440.

Haag, William G. "Field Methods in Archaeology." In American Archaeology Past and Future: A Celebration of the Society for American Archaeology 1935-1985. Washington: Smithsonian Institute Press, 1986, 63-76.

Hayes, William, C. "Egypt—To End of Twentieth Dynasty," in Chronology. Cambridge: Cambridge University Press, 1964.

Hedman, Matthew. The Age of Everything: How Science Explores the Past. Chicago: University of Chicago Press, 2007.

Hinsley, Curtis M. "From Shell-Heaps to Stelae: Early Anthropology at the Peabody Museum." In Objects and Others: Essays on Museums and Material Culture ed. George W. Stocking Jr. Madison: University of Wisconsin Press, 1985, 49-75.

Hojat, Mohammadreza, Joseph S Gonnella, and Addeanes Calleigh. "Impartial Judgment by the 'Gatekeepers' of Science: Fallibility and Accountability in the Peer Review Process." Advances in Health Sciences Education 8 (2003): 75-96.

Holton, Gerald, ed. Science and Culture: A Study of Cohesive and Disjunctive Forces. Boston: Houghton Mifflin Co, 1965.

Jennings, Jesse D. "River Basin Surveys: Origins, Operations, and Results, 1945-1969.” American Antiquity 50 (1985): 281-296.

Johnson, Frederick. "An archaeological Survey along the Alaska Highway, 1944.” American Antiquity 11, no 3 (1946): 183-186.

Johnson, Frederick, and Hugh M. Raup. Investigations in Southwest Yukon: Geobotanical and Archaeological Reconnaissance. Andover: Phillips Academy Papers of the Robert S Peabody Foundation for Archaeology, 1964.

Johnson, Frederick and O. J. Neill. "Some Ancient Sites in Greensburg and Ottawa Townships, Putnam County, Ohio." Science 26 (1961): 420-426.

Johnson, Frederick. “Anthropological Professional Associations." Yearbook of Anthropology (1955): 435439.

Johnson, Frederick. “Archaeological News.” American Journal of Archaeology 53 (1949): 286-301.

Johnson, Frederick. “Archaeological News.” American Journal of Archaeology 54 (1950): 235-253.

Johnson, Frederick. “Archaeological News.” American Journal of Archaeology 55 (1951): 255-268.

Johnson, Frederick. “Archaeology in Emergency.” Science 152 (1966): 1592-1597.

Johnson, Frederick. "A Quarter Century of Growth in American Archaeology." American Antiquity 27 (1961): 1-6.

Johnson, Frederick. “Editorial.” American Antiquity 9, no. 2 (1943), 161. 
Johnson, Frederick, et al. "Radiocarbon Dating: A Report on the Program to Aid in the Development of the Method of Dating." Memoirs of the Society for American Archaeology 8 (1951): 1-65.

Johnson, Frederick. “Half-Life of Radiocarbon.” Science 149 (1965): 1326.

Johnson, Frederick, et al. The Boylston Street Fishweir: A Study of the Archaeology, Biology, Geology of a Site on Boylston Street in the Back Bay District of Boston. Andover: Phillips Academy Papers of the Robert S Peabody Foundation for archaeology, 1942.

Johnson, Frederick. “Kirk Bryan: 1888-1950.” American Antiquity 16 (1951): 253.

Johnson, Frederick. "More Children' Jumping Rhymes." The Journal of American Folklore 42, no. 165 (1929): 305-306.

Johnson, Frederick. “Notes on Micmac Shamanism.” Primitive Man 16, no. 3/4 (1943): 53-80.

Johnson, Frederick. "Problems Surrounding the Classification of Certain Culture Complexes in New England." American Antiquity 3, no.2 (1937): 161-165.

Johnson, Frederick. "Radiocarbon Date Lists and Their Uses.” American Antiquity 21 (1956): 312-313.

Johnson, Frederick. “Radiocarbon Dates from Sandia Cave, Correction.” Science 125 (1957): 234-235.

Johnson, Frederick. "Teeth Mutilation Among the Guaymi." American Archaeologist 45 (1943): 327-328.

Johnson, Frederick. "The Impact of Radiocarbon Dating Upon Archaeology." Proceedings of the Sixth International Conference Radiocarbon and Tritium Dating: Held at Washington State University, Pullman Washington, June 7-11, 1965, ed. Roy M Chatters and Edwin A. Olson. Washington: Division of Industrial Research, 1965: 762-772.

Johnson, Frederick. "The Rodger's Collection from Lake Mistassini and Albanel, Province of Quebec." American Antiquity 14 (1948): 91-98.

Johnson, Frederick. "William Campbell Root, 1904-1969,” American Antiquity 35 (1970): 363-364.

Kauffman, George B. "In Memoriam Martin D. Kamen (1913-2002), Nuclear Scientist and Biochemist." Chemistry Educator 7 (2002): 304-308.

Krige, John. “Atoms for Peace, Scientific Internationalism, and Scientific Intelligence.” Osiris 21 (2006): 161-181.

Kuklick, Bruce. Puritans in Babylon: The Ancient Near East and American Intellectual Life, 1880-1930. Princeton: Princeton University Press, 1996.

Leopold, Ellen. Under the Radar: Cancer and the Cold War New Brunswick: Rutgers University Press, 2009.

Lewis, David Rich. "Still Native: The Significance of Native Americans in the History of the TwentiethCentury American West.” Western History Quarterly 24, no. 2 (1993): 203-227.

Libby, Willard. “Age Determination by Radiocarbon Content.” Willard F Libby Collected Papers, Vol. 1 Tritium and Radiocarbon, Geo Science Analytical, inc. 1981

Libby, Willard F. “Atmospheric Helium thee and Radiocarbon from Cosmic Radiation," Physical Review 69, no. 11-12 (1946), 671-672. 
Libby, Willard. "Chemistry and the Atomic Nucleus." U.S. Atomic Energy Commission. Washington: GPO, 1958.

Libby, Willard. “Chicago Radiocarbon Dates V.” Science 120 (1954): 733-742.

Libby, Willard. The Collected Papers of Willard F. Libby, Vol. VII, "Talking to People” Santa Monica: Geo Science Analytical, Inc., 1981.

Libby, Willard. The Collected Papers of Willard F. Libby, Vol. I Tritium and Radiocarbon Santa Monica: Geo Science Analytical, Inc., 1981.

Libby, Willard. "Natural Radiocarbon and Tritium in Retrospect and Prospect." In International Conference Radiocarbon and Tritium Dating: Held at Washington State University, Pullman Washington, June 7-11, 1965, ed. Roy M Chatters and Edwin A. Olson. Washington: Division of Industrial Research, 1965, 745-753.

Libby, Willard. "Radiocarbon Dating." Philosophical Transactions of the Royal Society of London. Series A, Mathematical and Physical Sciences 269 (1970): 1-10.

Libby, Willard. “Radiocarbon Dating.” Science 133 (1961): 621-629.

Linares, Olga F. Ecology and the Arts in Ancient Panama: On the Development of Social Rank and Symbolism in the Central Provinces. Washington: Dumbarton Oaks, 1977, (()(.

Lyman, R. Lee, and Michael J. O'Brien. The Rise and Fall of Culture History. New York: Plenum Press, 1997.

Lyon, Edwin A. A New Deal for Southeastern Archaeology. Tuscaloosa: University of Alabama Press, 1996.

MacNeish, Richard S. “Obituary: Frederick Johnson 1904-1994.” American Antiquity 61, no.2 (1996): 269-273.

Malina, Jaroslav, Zdenek Vasicek, and Marek Zvelebil, Archaeology Yesterday and Today: The Development of Archaeology in Sciences and Humanities. Cambridge: Cambridge University Press, 1990.

Marlowe, Greg. "W F Libby and the Archaeologists, 1946-1948." Radiocarbon 22 (1980): 1005-1014.

Marlowe, Greg. "Year One: Radiocarbon Dating and American Archaeology, 1947-1948." American Antiquity 64 (1999): 9-32.

Meltzer, David J., Fowler, Don D., and Jeremy A. Sabloff ed. American Archaeology: Past and Future: A Celebration of the Society for American Archaeology, 1935-1985. Washington: Smithsonian Institution Press, 1986.

Merton, Robert K., and Harriet Zuckerman. "Institutionalized Patterns of Evaluation in Science." In The Sociology of Science: Theoretical and Empirical Investigations. Chicago: University of Chicago Press, 1979, 460-497.

Merton, Robert K. "The Matthew Effect in Science: The Reward and Communications Systems of Science are Considered." Science 159 (Jan. 5, 1968): 56-63.

Meyer, Eduard. Agyptische Chronologie. Charleston: Bibliobazaar, 2010 (original 1904). 
Montagu, M. F. Ashley. "The Atomic Bomb and the Anthropologists.” Science 103, no. 2679 (1946): 547574.

Moses, L. G. The Indian Man: A Biography of James Mooney. Lincoln: University of Nebraska Press, 2002.

Nash, Stephen Edward. Time, Trees, and Prehistory: Tree-Ring Dating and the Development of North American Archaeology, 1914-1950. Ann Arbor: University of Michigan Press, 1999.

Nobleprize.org, biography of Willard Libby http://nobelprize.org/nobel_prizes/chemistry/ laureates/1960/libby-bio.html, accessed June 4, 2010

Norcini, Marilyn. "Frederick Johnson's Canadian Ethnology in the Americanist Tradition." Histories of Anthropology Annual 4 (2008): 106-134.

Norcini, Marilyn. "Frederick Johnson's 'River Desert Algonquin' Materials at the University of Pennsylvania Museum: A Collection History." Journal of the Council for Museum Anthropology 31, no. 2 (2008): 122-147.

Orlans, Hans. The Effect of Federal Programs on Higher Education: a Study of 36 Universities and Colleges. Washington: The Brookings Institute, 1962.

Panofsky, Wolfgang K. H. "Big Science and Graduate Education," in Science Policy and the University, ed. Hans Orlans. Washington D. C.: The Brookings Institute, 1968, 186-197.

Patterson, Thomas C. "The Last Sixty Years: Toward a Social History of Americanist Archaeology in the United States." American Anthropologist 88 (1986): 7-26.

Philips, Phillip, James A. Ford, and James B. Griffin. "Archaeological Survey in the Lower Mississippi, 1940-1947." Peabody Museum of American Archaeology and Ethnology, Papers, 25. Cambridge Massachusetts.

Polanyi, Michael, The Logic of Liberty: Reflection and Rejoinders. Chicago: University of Chicago Press, 1945.

Reid, Allen F. and John R Dunning, Sidney Weinhouse and Artistid V. Grosse. "Half Life of C14." Physical Review 70 (1946) 431.

Renfrew, Colin. Before Civilization: The Radiocarbon Revolution. New York: Alfred A. Knopf, 1973.

Renfrew, Colin. "The Great Tradition Verses the Great Divide: Archaeology as Anthropology?" American Journal of Archaeology 84 (1980): 287-298.

"River of Gold, Pre-Columbian treasures from Sitio Conte. http://www.penn.museum/traveling exhibits/351-river-of-gold.html. Accessed May 2010.

Robeson, Laura C. "Archaeology and Mission: The British Presence in Nineteenth Century Jerusalem." Jerusalem Quarterly 40 (2009).

“Science: The Philosopher's Stone.” Time August 15, 1955, http://www.time.com/time/ magazine/article/0,9171,807508,00.html, accessed, June 4, 2010.

Smithsonian Institution Research Information System. "Frederick Johnson Photograph collection, 1915 
-1931 (bulk 1925-1931).” http://sirisarchives.si.edu/ipac20/ipac.jsp?uri=full=3100001 !283411!0. Accessed May 2010.

Stocking, George Jr. "The Persistence of Polygenist Thought in Post-Darwinian Anthropology," in Race, Culture, and Evolution: Essays in the History of Anthropology. New York: Free Press, 1968, 4268.

Strong, Wm. Duncan, Frederick Johnson, and William S. Webb. "National Archaeological Resources." Science 102 (1945), 44.

Stumner, Louis M. "Radiocarbon Dates From the Central Coast of Peru." American Antiquity 26 (1961): 548-550.

Suess, Hans E. "The Early Radiocarbon Years: Personal Reflections." In Radiocarbon After Four Decades: An Interdisciplinary Perspective, ed. R.E. Taylor, A. Long, and R. S. Kra. New York: Springer-Verlag, 1992, 11-16.

Sullivan, Ronald. "Donald Collier, Museum Curator and Chicago Anthropologist, 83." New York Times February 11, 1995. Accessed at http://www.nytimes.com/1995/02/11/obituaries/donaldcollier-museum-curator-and-chicago-anthropologist-83.html.

Swartz jr., B.K. "The McKern 'Taxonomic' System and Archaeological Culture Classification in the Midwestern United States: A History and Evaluation.” Bulletin of the History of Archaeology 6, no. 1 (1996): 3-9.

Taylor, R. E. "Preface.” In Radiocarbon After Four Decades: An Interdisciplinary Perspective ed. R.E. Taylor, A. Long, and R. S. Kra. New York: Springer-Verlag, 1992.

Taylor, R. E. Radiocarbon Dating: An Archaeological Perspective. New York: Academia Press Inc., 1987.

Taylor, R. E. "The Beginnings of Radiocarbon Dating in American Antiquity: A Historical Perspective." American Antiquity 50 (1985): 309-325.

Taylor, R. E. “The Introduction of Radiocarbon Dating." In It's About Time: Archaeological Dating in North America, ed. Stephen E Nash. Salt Lake City: University of Utah Press, 2000, 84-104.

"The American Anthropological Society: Antecedent Conditions" New Series, Vol. 5, No. 1 (1903), 179181.

Trigger, Bruce G. "Archaeology and the Image of the American Indian." American Antiquity 45, no. 4 (1980): 662-676.

Trigger, Bruce G. A History of Archaeological Thought. Cambridge: Cambridge University Press, 2006.

Voss, Earl H. Nuclear Ambush: The Test Ban Trap. Washington: Regnery Publishing, 1963.

Wang, Jessica. American Science in an Age of Anxiety. Chapel Hill: University of North Carolina Press, 1999.

Wang, Jessica. "Science, Security, and the Cold War: The Case of E. U. Condon." Isis 83 (1992): 238269.

Webb, George E. Science in the American Southwest: A Topical History. Tucson: University of Arizona Press, 2002. 
Weinberg, Alvin M. "Impact of Large Scale Science on the United States." Science 134 (July 21, 1961): 161-164.

Wendorf, Fred, and Raymond H. Thompson. "The Committee for the Recovery of Archaeological Remains: Three Decades of Service to the Archaeological Profession.” American Antiquity 67, no. 2 (2002) 317-330.

Woodbury, Richard B. “Obituary: John Otis Brew, 1906-1988.” American Antiquity 55 (1990): 452-459.

Zuener, Frederick E. Dating the Past. London: Methuen and Company, 1958.

\section{ARCHIVES CONSULTED}

Los Angeles, The Charles E Young Research Library, The Frederick Johnson Papers, 1948-1968, no. 1295. Finding aid at http://www.oac.cdlib.org/findaid/ark:/13030/kt296nc30m. 


\section{Appendix A: Explanation of Radiocarbon Dating}

Carbon-14 (also referred to as $\mathrm{C} 14$ and radiocarbon) is a radioactive isotope form of carbon, created high in the Earth's atmosphere through the bombardment of nitrogen-14 by space-traveling cosmic rays. Though it is distinct from the stable and far more typical carbon12 , the minute quantities of carbon-14 (roughly one part per trillion) oxidize in the same manner as that of typical carbon-12, and becomes a part of the compound $\mathrm{CO}_{2}$, which travels down from the stratosphere to the earth's surface. ${ }^{308}$

The grand majority of carbon-14 (chemically bonded in $\mathrm{CO}_{2}$ ) is absorbed into the oceans (carbonate bicarbonate) though some enters the terrestrial biosphere (about 2\%) and is absorbed by plants, a percentage of which are in turn are consumed by animals, distributing the carbon-14 through the lifecycle. ${ }^{309}$ Animals and plants continue to replenish their carbon14 through carbon intake (food consumption, or in the case of plants-photosynthesis) until death, whereupon the amount of carbon-14 in the organic tissues ceases to be augmented.

The fact that radiocarbon replenishes within the lifecycle until death, paired with the known half-life of carbon-14 of roughly 5700 years, allows measurements of existing carbon14 in organic matter to yield a date of death for an organic life form. The recognition of this possibility by Willard Libby became the basis for carbon-14 dating, and Libby was awarded the Nobel Prize for chemistry in 1960 for the theoretical and technical achievements expressed in the creation of the method.

\footnotetext{
${ }^{308}$ Carbon-14 and carbon-13 are the only naturally occurring "radiocarbons" although carbon-10, carbon-11, and carbon-15 have been created in laboratory settings. Short explanations of the science behind radiocarbon are abundant, see Taylor, Radiocarbon Dating: An Archaeological Perspective. See also Libby, Radiocarbon Dating, as well as many other sources.

${ }^{309}$ R. E. Taylor, “The Introduction of Radiocarbon Dating," in It's about Time: A History of Archaeological Dating in North America, ed. Stephen E. Nash (Salt Lake City: University of Utah Press, 2000), 86.
} 
For carbon-14 measurements to be accurate, two presuppositions about the nature of carbon-14 and the terrestrial biosphere must be true: 1) that carbon-14 is distributed evenly through organic systems after its creation at high altitude, and 2) that carbon-14 has been created at a constant rate by cosmic rays through the period of recordable history. Libby's graduate student E. C. Anderson's doctoral dissertation was a test of the first assumption, and an assay of contemporary wood samples and animal meats (seal meat from Antarctica was collected, where there was no quantity of wood) were all tested and yielded a positive result. Later tests by others did demonstrate that Libby's first assumption was not entirely true-for example, the complex manner in which ocean currents turn over deep-sea water has meant that certain aquatic environments are carbon-14 rich or depleted. This and other caveats have not overturned the fundamental principles of carbon-14 distribution, but have been cause for certain adjustments to calibration techniques or to expectations in certain testing scenarios. For example, the discovery of the slow mixing of deep sea waters which effects the deep-sea carbon-14 reservoir is now understood to make many seashells suspect candidates for carbon dating.

The second assumption — that carbon-14 has been created uniformly over measurable time-proved harder to test and was not truly dealt with until radiocarbon dates were compared to dendechronological dates in the 1950s. In the end, dendrechonological derived dates revealed a need for some calibration of radiocarbon dates due to shift in the magnetic field, and its subsequent effect on cosmic radiation (and therefore, on carbon-14 production) now known as the de Vries effect. ${ }^{310}$ Though again, this discovery demonstrated the need for calibration of radiocarbon dates and did not prove fatal to the dating method.

\footnotetext{
${ }^{310}$ In addition, there is evidence that periods of solar flare production by the sun decrease the amount of cosmic rays reaching the earth and hence decrease the production of carbon-14. Equally, it has
} 
The initial method of counting the carbon-14 present in a sample that Libby devised involved converting the sample to a gaseous state-either carbon dioxide or methane-and collecting data with a "screen wall counter," a variation of the Geiger counter Libby had developed in $19333^{311}$ Of important note, particularly to archaeologists, is that the sample was destroyed during testing.

been noted that atomic testing attributed to higher amount s of carbon-14 in the atmosphere, though the burning of fossil fuels dilutes carbon-14. See R. E. Taylor, "The Introduction of Radiocarbon Dating,"

${ }^{311}$ Willard Libby, Radiocarbon Dating (Chicago: University of Chicago Press, 1952) 52, and also Tyler, Archaeological Perspective, 148 (diagram). 


\section{Appendix B: The Viking Fund}

Frederick Johnson began his relationship with the Viking Fund while working for the CRAR. The relationship with the fund and director Paul Fejos, would become an important part of funding for the Committee on Radioactive Carbon 14. therefore, a brief explanation of the Viking fund is required.

The Viking Fund was a philanthropic funding organization for anthropology with headquarters in New York, 14 East $71^{\text {st }}$ Street. ${ }^{312}$ It had been established in 1941 when Swedish industrialist Axel Wenner-Gren set 2.5 million dollars aside to support "scientific, educational, and charitable enterprises." ${ }^{313}$ Issues of legality complicated the fund's status: the U.S. state department accused Wenner-Gren of wartime collusion with the Nazis. For this reason, the 2.5 million "could not be withdrawn from the United States since the Internal Revenue Service had a suit pending against the Swedish Industrialist." 314 Though the charges were not substantiated, the sense that Viking Fund money was "dirty," persisted well after the war and was a part of the image of the fund many archaeologists accepted. ${ }^{315}$

A Hungarian medical doctor who had a self-taught knowledge of ethnology and archaeology, Dr. Paul Fejos, directed the fund. ${ }^{316}$ In the period after the war the fund

${ }^{312}$ Ruth Benedict, “The Viking Fund,” American Anthropologist 49, no. 3, (1947), 1.

${ }^{313}$ Benedict, 1 .

${ }^{314}$ Greg Marlowe, “W.F. Libby and the Archaeologists, 1946-1948," Radiocarbon 22, no. 3 (1980), 1011.

${ }^{315}$ Marlowe, "W.F. Libby Amongst the Archaeologists," 1011.

${ }^{316}$ Dr. Paul Fejos had a diverse career. He was a Hungarian born medical doctor who immigrated to the United States in 1924 and made four films in Hollywood before becoming the director of the Viking fund in 1941. See John Wendell Dodds, The Several Lives of Paul Fejos, (New York, Wenner-Gren Foundation, 1973). 
provided numerous tools for anthropologists and archaeologists in a proximity to New York-the building was used to host bi-monthly dinners in which scientists could discuss aspects of practice, and the building also housed a library, equipment for "sound-recording, mimeographing, microfilming, and photographic development and printing," and also was available for meetings of anthropologically oriented groups and societies. ${ }^{317}$ More importantly (for Johnson and practitioners like him), the organization provided funds for both fieldwork and the publication of findings.

The philanthropic institution, under Fejos direction, was particularly interested in finding interdisciplinary endeavors, or projects that melded the technologies/theories of other scientific fields into the field practice of anthropology. Fejos vision was that the fund would "pioneer in new approaches_-the risk bearing areas of research-involving cooperative and cross-disciplinary research."318 In 1947, the fund supported endocrine research, cranial research in primates, work in linguistics, and a cultural study of Hollywood, amongst other endeavors. Similarly, the organization funded collaborative projects between departments at Yale, and co-funded work done by the Institute of Ethnic Affairs, and the National Research council. ${ }^{319}$

\footnotetext{
${ }^{317}$ Benedict, 1 .

${ }^{318}$ Marlowe, "W.F. Libby," 1007.

${ }^{319}$ Benedict, 528-529. Johnson worked closely with Fejos throughout the postwar period. He received funding for at least two projects from the Viking Fund before hi work on carbon-14: he had procured 2,500 for the planning committee of the SAA, and 10,000 was bestowed for his work in the Yukon with botanist Hugh Raup. See Benedict, 2. Also Marlowe, "Year One," 19.
} 


\section{Appendix C: Acronyms and Abbreviations}

AAA-American Anthropological Association

AIA - Archaeological Institute of America

AJA-American Journal of Archaeology (published by the AIA)

CRC14-Committee on Radioactive Carbon 14 (later, The Committee for Radiocarbon Dating.

FJP—Frederick Johnson Papers (the Charles E. Young Research Library, UCLA)

SAA — Society for American Archaeology 